\title{
CARACTERIZAÇÃO GENÉTICA DE ESTIRPES DE Phytophthora parasitica, ISOLADAS DE PLANTAS CÍTRICAS NO ESTADO DE SÃO PAULO
}

\section{CARLOS IVAN AGUILAR-VILDOSO}

Engenheiro Agrônomo

Orientador : Prof. Dr. JOÃO LÚCIO DE AZEVEDO

\begin{abstract}
Dissertação apresentada à Escola Superior de Agricultura "Luiz de Queiroz", Universidade de São Paulo, para obtenção de título de Mestre em Agronomia, Área de concentração: Genética e Melhoramento de Plantas.
\end{abstract}

P I R A C I C A B A

Estado de São Paulo - Brasil

Abril - 1997 
Dados Internacionais de Catalogação na Publicação (CIP) DIVISÃo DE BIBLIOTECA E DOCUMENTAÇÃO - Campus “Luiz de Queiroz"/USP

Aguilar-Vildoso, Carlos Ivan

Caracterização genética de estirpes de Phytophthora parasitica, isoladas de plantas cítricas no Estado de São Paulo / Carlos Ivan Aguilar-Vildoso. - - Piracicaba, 1997.

98 p. : il.

Dissertação (mestrado) - - Escola Superior de Agricultura Luiz de Queiroz, 1997.

Bibliografia.

1. Citricultura 2.Fruta citrica 3. Fungo fitopatogênico 4. Genética microbiana 5. Marcador molecular 6. Resistência ao fungicida 7. Variação genética I. Título

CDD 589.252

632.42 


\title{
CARACTERIZAÇÃO GENÉTICA DE ESTIRPES DE Phytophthora parasitica, ISOLADAS DE PLANTAS CÍTRICAS NO ESTADO DE SÃO PAULO
}

\author{
CARLOS IVAN AGUILAR-VLDOSO
}

Aprovada em: 23.06.97

Comissão julgadora:

Prof. Dr. João Lúcio de Azevedo

ESALQ/USP

Prof $^{\mathrm{a}}$. Dr ${ }^{\mathrm{a}}$. Maria Helena Pelegrinelli Fungaro

UEL

Dr. Jorgino Pompeu Junior

CCSM/IAC

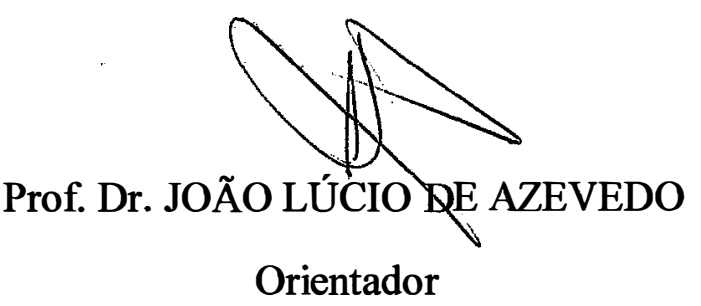




\title{
Dedicatória
}

\author{
À minha mãe, pelo seu ideal e \\ força interior na orientação da \\ minha vida
}

Ao meu pai e Rita, por conceder me a oportunidade de estudar e me acolher no momento oportuno

À minha irmã Tania, pela dedicação e anos de vida conjunta

A minha mulher, por todos os momentos de nossa vida juntos, pelo apoio, auxílio, compreensão e amor; sem o qual não conseguiria atingir meus ideais. 


\section{AGRADECIMENTOS}

Em especial ao meu orientador Dr. João Lúcio de Azevedo, pela oportunidade que me concedeu, permitindo a realização dos meus trabalhos, e pelos ensinamentos que percebemos e reconhecemos, agradeço.

Aos Professores. do Departamento de microbiologia da Universidade Federal de Viçosa, pelos primeiros passos e ensinamentos. Em especial à $\operatorname{Dr}^{\mathrm{a}}$ Rosa M. Castro Muchovej, à Dr ${ }^{\mathrm{a}}$ Catarina Kasuya, à Dr ${ }^{\mathrm{a}}$. Elza Fernandes e ao Dr. Daison Olsani pela visão inicial de genética e pelo respeito aos microrganismos, fonte do nosso estudo.

Ao Dr. Cláudio Messias da UNICAMP, pelos conselhos oportunos no momento decisivo, que mudaram a minha vida profissional.

Ao pesquisador Eduardo Feichtenberger, do Laboratório Regional de Sorocaba do Instituto Biológico de São Paulo, pelo voto de confiança e a grande ajuda que representa no presente trabalho e no dia a dia.

À Dr ${ }^{\mathrm{a}}$. Aline Ap. Pizzirani-Kleiner pela sua amizade e ao grande auxílio que representou; assim como ao Zezo pelo constante ajuda nas minhas atividades no Laboratório.

Ao Departamento de Genética pelo treinamento e auxílio de todos, em especial à Dra. Maria Lúcia pela sua atitude, decisiva na continuação do meu trabalho. Aos funcionários do Departamento Leia, Carmen, Silvana, Beti e Fernando, meu muito obrigado. Aos amigos da Genética, Gilda, Angela , Rainerio, Inês, Raolindo, Angélica, Rogério, João, Alexandre, Anelise, Margarete, Derlene, Gislaine, Joelma, Fábio e os muitos outros que não mencionei, agradeço pela amizade e bons momentos .

A Welington Araújo, André Lima e Chirlei Glienke, pela amizade, pelas conversas e todos os momentos agradáveis que me forneceram, e que continuaremos a ter.

A Walter Maccheroni pelo acompanhamento durante o trabalho e a sua paciência. 
À $\mathrm{Dr}^{\mathrm{a}}$. Maria Helena Fungaro pelos ensinamentos em cada encontro.

Ao Dr. Tasso Krugner, pela sua recepção e atenção, meu muito obrigado.

A toda a equipe do Centro de Citricultura Sylvio Moreira do Instituto Agronômico de Campinas, desde o pessoal de apoio até os pesquisadores, para os quais não há palavras para agradecer os ensinamentos de cada dia, pela compreensão e auxilio em todos os momentos que estamos compartilhando juntos, que as linhas para agradecer não são suficientes para o que representam e realizaram por mim.

Ao Dr. Jorgino Pompeu Júnior pela minha formação na pesquisa citrícola e visão das necessidades e contradições da pesquisa e a produção.

Ao Dr. Joaquim Teófilo Sobrinho, que permitiu meus estudos e a lembrança das suas qualidades políticas e de bom relacionamento com todos os setores da citricultura.

Ao Dr. José Orlando Figueiredo pela amizade de todo dia e aos seus conselhos sempre positivos, e tão importantes para todos que o cercam.

Dr. Marcos Machado porque temos que ser sempre eficientes.

À Dr $^{\mathrm{a}}$. Mariângela Cristofani pela amizade e luta contínua nas nossas atividades de estudante e profissional, construindo no dia a dia os nossos trabalhos.

A Francisco Ferraz Laranjeira, amigo a tanto tempo, sem o qual não teria a chance de estar onde estou, conversando e consentindo meus maus momentos, meu muito obrigado. Aos estagiários com os quais sempre estou aprendendo e pelo apoio nas minhas decisões; em especial a Anderson Campos, Manuel Teixera, Nadia Gonçalves e a Luciano Borges; que acreditaram e continuaram mesmo nos momentos mais dificeis, meu muito obrigado. À Fundação IAC e ao Fundecitrus pelo apoio econômico na realização dos meus trabalhos; e em especial à CAPES pela concessão da bolsa de estudos.

A todos os que contribuíram para a realização deste trabalho e na minha formação profissional, direta ou indiretamente, o meu muito obrigado. 


\section{SUMÁRIO}

Página

LISTA DE FIGURAS.................................................................... ix

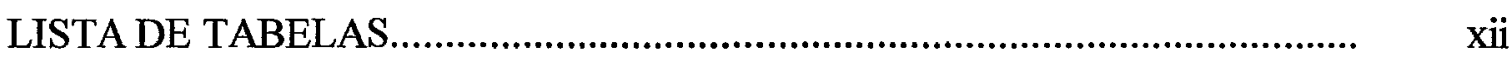

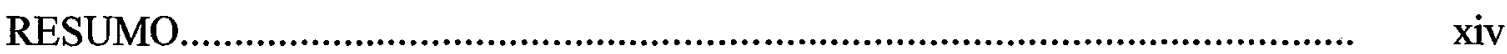

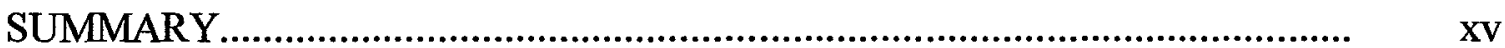

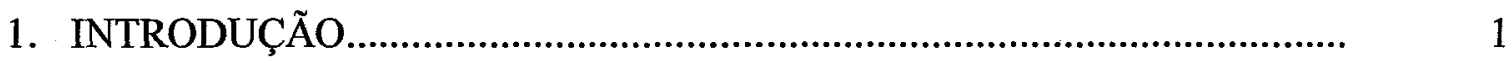

2. REVISÃO DE LITERATURA........................................................ 3

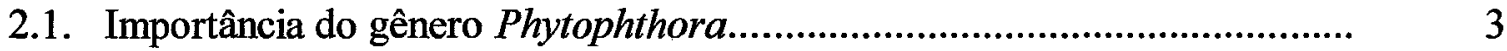

2.2. Histórico do patógeno na citricultura..................................................

2.2.1. Identificação de espécies de Phytophthora em citros pelo mundo........... $\quad 4$

2.2.2. Estudos de espécies de Phytophthora em citros no Brasil...................... 6

2.3. Morfologia de Phytophthora ...................................................... 7

2.4. Taxonomia do gênero Phytophthora ................................................ 10

2.5. Variabilidade em fungos fitopatogênicos............................................ 16

2.6. Resistência a fungicidas............................................................. 17

2.7. Técnicas moleculares no estudo de patógenos de plantas........................ 18

2.8. Marcadores moleculares................................................................. . 20

2.9. RAPD (Polimisfismo de DNA amplificado ao acaso)............................. 21

2.10. RAPD em patógenos de plantas.................................................... 22

3. MATERIAL E MÉTODOS................................................................. 24

3.1. Microrganismos...................................................................... 24

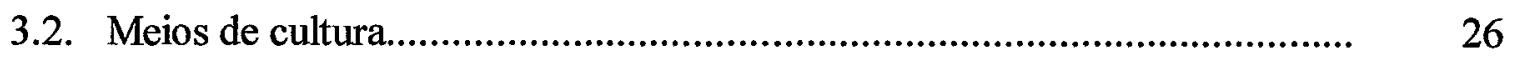




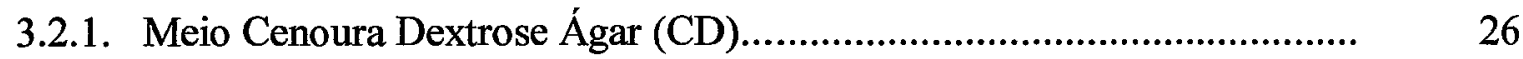

3.2.2. Meio Cenoura Ágar (CA)............................................................ 26

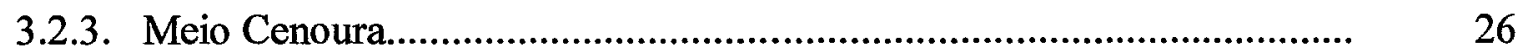

3.2.3.1. com liquidificador.............................................................................. 27

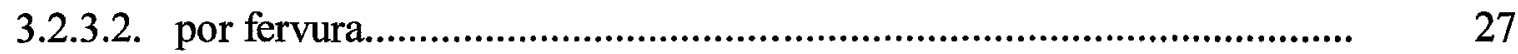

3.3. Manutenção das culturas estoques............................................................. 27

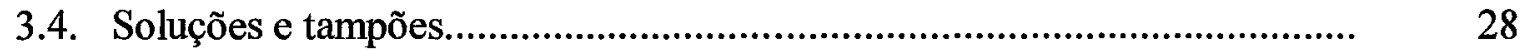

3.4.1. Solução de PVL...................................................................................... 28

3.4.2. Tampão de extração de DNA...................................................................... 28

3.4.3. Solução de acetato de potássio (para 100ml)............................................ 28

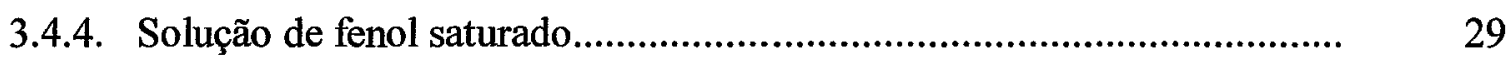

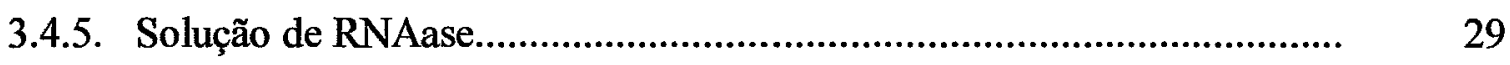

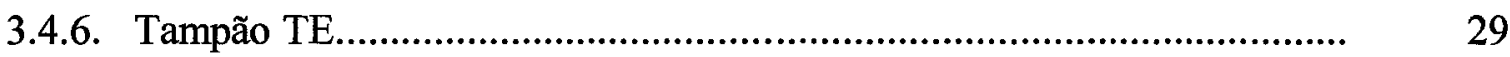

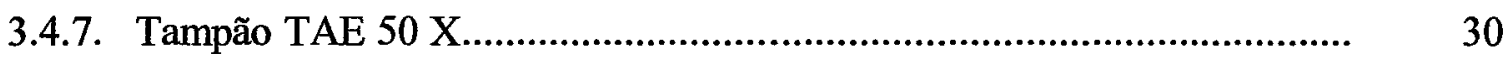

3.4.8. Tampão TAE 1 X.......................................................................... 30

3.4.9. Gel de agarose $(0.8 \%)$.........................................................................

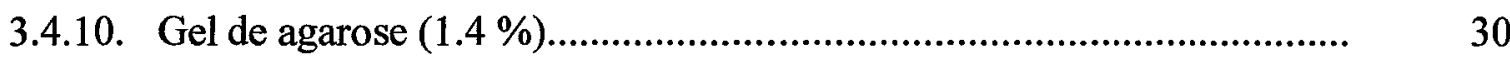

3.4.11. Tampão de corrida.......................................................................... 30

3.4.12. Solução de brometo de etídio (1\%)...................................................... 31

3.4.13. Solução de dNTP's......................................................................... 31

3.4.14. Solução tampão para reação de amplificação por RAPD ........................ 31

3.4.15. Solução de 10.000 ppm de metalaxyl..................................................... 32

3.5. Obtenção de culturas monozoospóricas........................................................ 32

3.5.1. Indução de produção e liberação de zoósporos........................................... 32

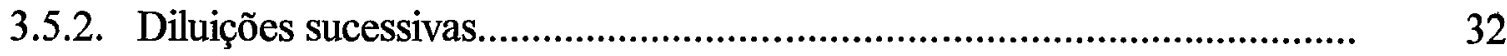


3.6. Manutenção da patogenicidade dos isolados................................................... 33

3.7. Caracterização morfológica dos isolados de Phytophthora........................... 33

3.8. Caracterização cultural dos isolados de Phytophthora .................................. 34

3.9. Taxas de crescimento dos isolados a $37^{\circ} \mathrm{C}$............................................... 34

3.10. Determinação do efeito do metalaxyl............................................................ 35

3.11. Determinação das equações das curvas de crescimento................................ 35

3.12. Produção do micélio fúngico......................................................................... 35

3.12.1. A partir de discos de meio CA com micélio sem agitação......................... $\quad 35$

3.12.2. A partir de discos de meio CA com micélio com agitação......................... 36

3.12.3. A partir da inoculação com zoósporos no meio ....................................... 36

3.12.3.1. Cenoura triturada em liquidificador....................................................... 36

3.12.3.2. Cenoura fervida................................................................................. 36

3.13. Extração de DNA................................................................................. 36

3.14. Integridade do DNA.............................................................................. 38

3.15. Quantificação do DNA........................................................................... 38

3.16. Otimização da técnica de RAPD................................................................. 39

3.16.1. Atividade da enzima Taq DNA polimerase............................................... 39

3.16.2. Quantidade de DNA.......................................................................... 39

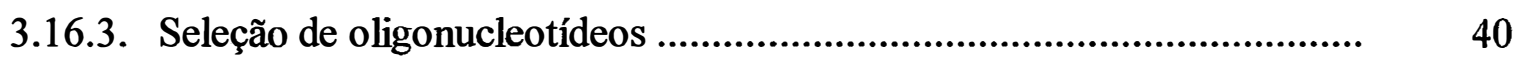

3.17. RAPD dos isolados de $P$. parasitica.......................................................... 42

3.18. Análise das bandas amplificadas por RAPD.............................................. 42

3.18.1 Análise entre indivíduos ............................................................................ 43

4. RESULTADOS E DISCUSSÃO ............................................................. 44

4.1. Reativação da patogenicidade dos isolados de $P$. parasitica.......................... 44

4.2. Caracterização morfológica dos isolados de $P$. parasitica ............................... 


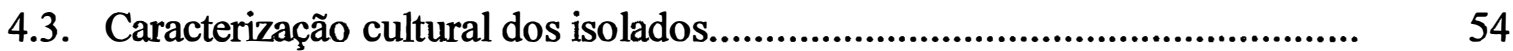

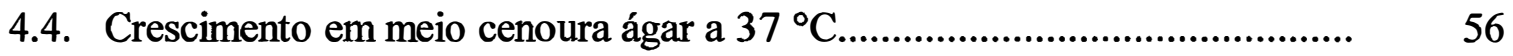

4.5. Efeito do metalaxyl nos diferentes isolados................................................... 59

4.6. Otimização das condições de produção do micélio fúngico............................ 68

4.7. Otimização das condições de RAPD............................................................... 70

4.7.1 Otimização da quantidade de DNA na reação de amplificação..................... $\quad 70$

4.7.2 Otimização do número de unidades da enzima Taq DNA polimerase para

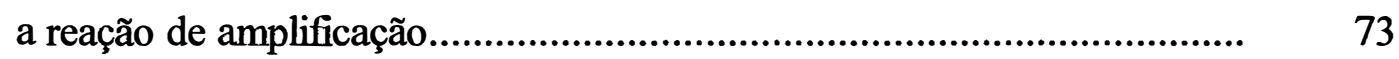

4.7.3 Seleção de oligonucleotídeos na reação de amplificação................................ 75

4.8. Bandas originadas por RAPD................................................................

4.9. Polimorfismo obtido por RAPD.............................................................. 82

4.10. Dados moleculares $x$ fenótipos ………………………............................. 84

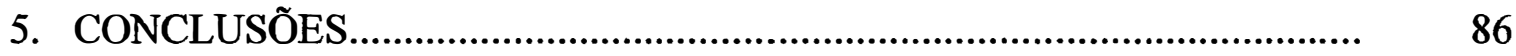

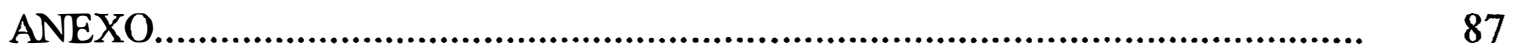

REFERÊNCIAS BIBLIOGRÁFICAS.......................................................... 89 


\section{LISTA DE FIGURAS}

Página

1 Localização das culturas originais dos isolados de Phytophthora, no mapa do Estado de São Paulo.

2 Esporângio caduco $(51 \times 25 \mu \mathrm{m})$ com pescoço e pedicelo curto $(2 \mu \mathrm{m})$.........

3 Variação morfológica dos esporângios: (a) obpiriforme ( $45 \times 26 \mu \mathrm{m})$; (b) esférico $(27$ x $23 \mu \mathrm{m})$; e (c) ovóide com inserção intercalar $(58 \times 36 \mu \mathrm{m}) \ldots . .$.

4 Clamidósporo a) intercalar ( $38 \mu \mathrm{m}$ de diâmetro) e b) terminal $(26 \mu \mathrm{m}$ de diâmetro)

5 Presença de oogônio no isolado IAC $15 / 95$ (16.5 x $15 \mu \mathrm{m})$.

53

6 Variação do aspecto cultural das colônias de $P$. parasitica em meio cenoura ágar (CA), a) cotonoso; b) crisântemo; c) estrelado; d) rosáceo e e) rosáceo-petalóide.

7 Curvas de crescimento do diâmetro das colônias dos isolados de $P$. parasitica a $37^{\circ} \mathrm{C}$ em meio cenoura-ágar.

8 Curvas de crescimento em diâmetro das colônias dos isolados IAC 01/95, IAC 02/95, IAC 03/95 e IAC 04/95, em 0; 1; 10 e 100 ppm de metalaxyl em meio cenoura ágar (CA). 
8 Curvas de crescimento em diâmetro das colônias dos isolados IAC 06/95, IAC 07/95, IAC 08/95 e IAC 09/95, em 0; 1; 10 e 100 ppm de metalaxyl em meio cenoura ágar $(\mathrm{CA})$

8. Curvas de crescimento em diâmetro das colônias dos isolados IAC 10/95, IAC 11/95, IAC 12/95 e IAC 13/95, em 0; 1; 10 e 100 ppm de metalaxyl em meio cenoura ágar (CA).

8 Curvas de crescimento em diâmetro das colônias dos isolados IAC 14/95, IAC 15/95, IAC 16/95 e IAC 17/95, em 0; 1; 10 e 100 ppm de metalaxyl em meio cenoura ágar (CA)

9 Efeito do metalaxyl no aspecto das hifas de $P$. parasitica, a) aspecto normal no meio cenoura ágar; b) aspecto com $10 \mathrm{ppm}$ de metalaxyl no meio cenoura ágar (CA)

10 Aspecto do crescimento micelial, a) com agitação a $100 \mathrm{rpm}$ a $28^{\circ} \mathrm{C} \mathrm{e} \mathrm{b)} \mathrm{sem} \mathrm{agitação} \mathrm{à} \mathrm{temperatura} \mathrm{ambiente}$

11 Otimização da quantidade de DNA na reação de amplificação, com os isolados IAC 01/95 (a, c, e) e IAC 02/95 (b, d, f); com 10; 20; 40; 60; 80; $100 \mu \mathrm{g}$ de DNA e três oligonucleotídeos iniciadores OPE - 06 (a, b); OPE - 15 (c, d) e OPE - $18(e, f)$ 
12 Otimização do número de unidades da enzima Taq DNA polimerase para a reação de amplificação....................................................

13 Seleção de oligonucleotídeos para a reação de amplificação por RAPD, com o DNA do IAC 01/95, de dois kits da Operon (E e X); as canaletas do gel continham: P (lamda clivado); E1 (coluna 1), E2 (coluna 2), E3 (coluna 3), E4 (coluna 4), E5 (coluna 5), E6 (coluna 6), E8 (coluna 7), E9 (coluna 8), E10 (coluna 9), E11 (coluna 10), E12 (coluna 11), E13 (coluna 12), E14 (coluna 13), E15 (coluna 14), E16 (coluna 15), E17 (coluna 16), E18 (coluna 17), E19 (coluna 18), P (lamda clivado), E20 (coluna 19), X1 (coluna 20), X2 (coluna 21), X3 (coluna 22), X4 (coluna 23), X5 (coluna 24), X6 (coluna 25), X7 (coluna 26), X8 (coluna 27), X9 (coluna 28), X11 (coluna 29), X12 (coluna 30), X18 (coluna 31), X13 (coluna 32) e X14 (coluna 33).

14 Amplificação do DNA dos isolados de $P$. parasitica com os oligonucleotídeos a) OPE - 08 e b) OPX - 04; os números das colunas representam os códigos das estirpes.

15 Distribuição dos fragmentos de DNA amplificados de $P$. parasitica (a) escala linear (b) escala logarítmica 


\section{LISTA DE TABELAS}

Página

1 Isolados originais, procedência no Estado de São Paulo e denominação das culturas monozoospóricas de $P$. parasitica.

2 Oligonucleotídeos iniciadores utilizados na otimização na quantidade de DNA necessária para a reação de amplificação pela técnica de RAPD, com as suas respectivas sequências de bases e percentagem de bases CG na sua constituição

3 Triagem de oligonucleotídeos iniciadores para a posterior avaliação do polimorfismo dos isolados por RAPD, com suas respectivas sequências de bases e percentagem de bases CG na sua constituição

4 Oligonucleotídeos iniciadores utilizados na detecção do polimorfismo entre isolados, com as respectivas sequências de bases e percentagem de bases CG na sua constituição

5 Caracterização dos esporângios nos isolados de $P$. parasitica em meio cenoura ágar (CA)

6 Forma dos esporângios nos diferentes isolados de $P$. parasitica em meio CA 
7 Média das mensurações dos esporângios dos isolados de $P$. parasitica em meio CA, após 15 dias de crescimento.

8 Aspecto cultural dos isolados de $P$. parasitica em meio CA.

9 Coeficiente da regressão linear obtidas para o crescimento dos

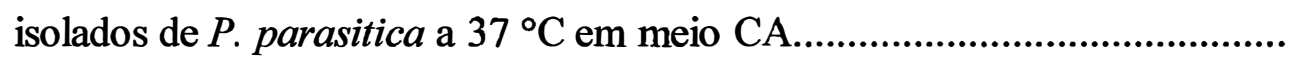

10 Estimativa da taxa de crescimento em diâmetro das colônias dos isolados de $P$. parasitica a $25^{\circ} \mathrm{C}$ em meio CA em diferentes concentrações de metalaxyl

11 Percentagem (\%) na inibição da taxa de crescimento em diâmetro das colônias de $P$. parasitica em meio CA pelo fungicida metalaxyl a $25^{\circ} \mathrm{C}$.....

12 Número de bandas amplificadas pelos oligonucleotídeos empregados na amplificação do DNA dos isolados de $P$. parasitica por RAPD

13 Bandas amplificadas de $P$. parasitica pela técnica de RAPD, código das bandas, estimativa do peso molecular $(\mathrm{Kb})$ das bandas amplificadas e frequência de ocorrência 


\title{
CARACTERIZAÇÃO GENÉTICA DE ESTIRPES DE Phytophthora parasitica, ISOLADAS DE PLANTAS CÍTRICAS NO ESTADO DE SÃO PAULO
}

\author{
Autor: Carlos Ivan Aguilar-Vildoso \\ Orientador : Prof. Dr. João Lúcio de Azevedo
}

RESUMO

Culturas monozoospóricas de Phytophthora, num total de dezesseis, originarias do Estado de São Paulo, foram estudadas quanto as suas características morfológicas, culturais, moleculares e sensibilidade ao fungicida metalaxyl. Todos os isolados foram identificados como $P$. parasitica pelas suas características morfológicas, culturais e fisiológicas. Houve diferenças estatísticas entre os isolados quanto a suas dimensões no comprimento (c), largura (l) e relação c/l dos esporângios em meio cenoura-dextrose, incubados a $25{ }^{\circ} \mathrm{C}$; assim como na capacidade de produção de clamidósporos no mesmo meio. Todos os isolados foram sensíveis ao metalaxyl, todos crescendo na concentração de 1 ppm, a maioria na concentração de 10 ppm e alguns isolados a $100 \mathrm{ppm}$, apesar que no último caso ao redor do disco que continha micélio do patógeno. $\mathrm{O}$ qual vem a demonstrar que há genótipos com alguma tolerância ao produto no Estado de São Paulo. Essa tolerância teve uma distribuição independente do local de isolamento e a análise molecular com a técnica de RAPD não foi suficientemente sensível para detectar grupos com similaridade genética com essa característica. A técnica de RAPD conseguiu distinguir os isolados, mas observou-se uma baixa diversidade genética entre eles, apesar de terem sido isolados em diferentes pontos do Estado. Mesmo assim houve diferenças entre isolados provindos da mesma cultura original. 


\title{
GENETIC CHARACTERIZATION OF Phytophthora parasitica STRAINS, ISOLATED FROM CITRUS IN SÃO PAULO STATE
}

\author{
Author: Carlos Ivan Aguilar-Vildoso \\ Adviser : Prof. Dr. João Lúcio de Azevedo
}

SUMMARY

Phytophthora cultures from São Paulo State, were studied while their morfological, cultural, molecular and metalaxyl sensibility. All strains were identificated as P. parasitica. There was statistics differences among the strains in the large (1), (c) and $1 / \mathrm{c}$ ratio of sporangium in carrot-dextrose-agar medium at $25^{\circ} \mathrm{C}$; and the capacity of clamidospore production. Some strains growth in the medium with metalaxyl at $100 \mathrm{ppm}$, but their growth rate were very small and their aspect of the cultures were very disperced. The growth in $10 \mathrm{ppm}$ of metalaxyl as a evidence that exist a relatively tolerance to the metalaxyl. This tolerance have been a independent distribution of local isolation and molecular analyse. RAPD markers differencied among strains, but with low diversity in this fungi group. 


\section{INTRODUÇÃo}

A citricultura é de suma importância econômica para o Brasil, possuindo entre as suas principais doenças fúngicas as causadas pelo gênero Phytophthora. No início do melhoramento dos cítricos foi uma das responsáveis pelo emprego de enxertia; sistema de propagação vegetativa que aliou a capacidade produtiva e qualidade dos frutos das laranjeiras susceptíveis, com as características de resistência às doenças e adaptação às condições edafoclimáticas dos porta-enxertos.

Apesar de terem sido descritas várias espécies deste gênero associadas com citros, as de maior importância são $P$. parasitica e $P$. citrophthora. Elas podem causar doenças em citros como o tombamento de plântulas, a podridão de radicelas, a podridão do colo, a gomose no tronco e a podridão parda dos frutos. A incidência e severidade das doenças por elas causadas vem oscilando segundo as mudanças nas práticas agrícolas e pelo surgimento de outras doenças com diversos agentes etiológicos, tendo como principal exemplo Tristeza, virose que levou ao predomínio do limão Cravo como principal portaenxerto do Estado de São Paulo, apesar da sua moderada susceptibilidade a Phytophthora.

Atualmente há necessidade de diversificação de porta-enxertos, substituindo o limão Cravo. Entre os vários indicados pela pesquisa muitos são de maior susceptibilidade a Phytophthora, além do que as recomendações atuais de formação dos 
pomares com clones nucelares e irrigação predispõem as plantas cítricas às doenças de Phytophthora.

É de extrema importância para o programa de melhoramento de porta-enxertos e para o próprio controle da doença, o conhecimento da variabilidade genética desse patógeno, assim como da possível ocorrência de biótipos e a necessidade de estimar a capacidade adaptativa dos isolados disseminados na região citrícola paulista.

Biótipos resistentes a metalaxyl já foram observados nos Estados Unidos e em outros países, o qual é um dos poucos fungicidas sistêmicos recomendados para o controle da doença. Esse fato reforça a importância do estudo e o monitoramento da resistência aos fungicidas.

Apesar do surgimento de novas doenças como a Clorose Variegada e a Queda Prematura dos Frutos Cítricos, tendo como agentes etiológicos Xylella fastidiosa e Colletotrichum gloeosporioides (atualmente identificado como C. acutatum) respectivamente, não pode ser negligenciado o estudo de patógenos como Phytophthora, e outros com os quais a citricultura vem convivendo e sofrendo perdas contínuas e significativas. $O$ presente estudo teve a finalidade de obter informações sobre a variabilidade genética de isolados de Phytophthora parasitica no Estado de São Paulo, utilizando marcadores RAPD, técnica que pode ser usada sem um prévio conhecimento da genética do organismo. Teve também o objetivo de avaliar a possível resistência ao fungicida metalaxyl entre as estirpes estudadas. 


\section{REVISÃO DE LITERATURA}

\section{1. Importância do gênero Phytophthora}

Quando se fala de Phytophthora sempre é lembrado o grande impacto socioeconômico ocorrido como a requeima da batata ( $P$. infestans) no século XIX, responsável pela fome de milhões de irlandeses e ingleses, e subsequente migração para outros países. Isto exemplifica bem porque do gênero Phytophthora é um dos mais importantes entre os fungos fitopatogênicos. Nas espécies desse taxon há uma grande variação quanto à gama de hospedeiros, desde generalistas como $P$. parasitica e $P$. cinnamomi até os altamente especializados como $P$. infestans e $P$. idaei. $\mathrm{O}$ grupo afeta grande número de espécies cultivadas de importância socio-econômica para a população mundial, assim como muitas plantas não cultivadas pelo homem. Continuamente novas doenças são descritas para esse grupo de patógenos em diferentes espécies de plantas, citando-se novos hospedeiros para algumas ou ainda propondo-se uma nova espécie, quando os recursos taxonômicos disponíveis não permitem a identificação do patógeno (Luz \& Matsuoka, 1996), como ocorreu recentemente para P. idaei (Kennedy \& Duncan, 1995) e $P$. italica (Cacciola et al, 1996).

A estimativa dos danos econômicos causados por espécies do gênero Phytophthora é provável estar em torno de dezenas de bilhões de dólares anualmente (Erwin \& Ribeiro, 1996). No Estado de Ohio, nos Estados Unidos, há uma perda em torno de 50 milhões de dólares por ano, no cultivo da soja por podridões de raízes (McBlain et al., 1991), não ficando longe dos 40 milhões anuais na citricultura brasileira. Entretanto na cultura do cacau as perdas pela podridão parda dos frutos são de aproximadamente 4 bilhões de dólares, atingindo de 10 a $30 \%$ da produção mundial (Evans \& Prior, 1987), enquanto no Brasil é em torno de 20\% (Zambolim \& Vale, 1985).

$\mathrm{Na}$ citricultura mundial, o gênero Phytophthora causa a mais séria doença do solo. Esse grupo é amplamente distribuído no mundo citrícola, causando perdas na produção desde regiões áridas até regiões tropicais com grandes precipitações pluviométricas (Timmer \& Menge, 1996). As perdas ocorrem em todas as fases de 
produção dos cítricos: na sementeira por "damping-off"; em viveiros por gomose e podridões do colo e das raízes; nos pomares por podridões do colo e das radicelas, gomose e podridão parda dos frutos; e em pós-colheita pela podridão parda (Feichtenberger, 1996).

No Brasil, $P$. citrophthora e $P$. parasitica são os principais agentes da gomose dos citros (Feichtenberger, 1989), mas no Estado de São Paulo P. parasitica é predominante na região citrícola (Rossetti et al., 1972).

\subsection{Histórico do patógeno na citricultura}

\subsubsection{Identificação de espécies de Phytophthora em citros pelo mundo}

Atualmente 13 espécies do gênero Phytophthora vem sendo relatadas associadas aos citros. Entretanto, as principais identificações das espécies relacionadas a citros foram realizadas até a década de 40, após a qual somente ocorreu em países onde ainda não eram relatadas. Segundo relatos de Fawcett (1936), apesar das citações de Ibn el Awan, botânico árabe, sobre a menção de uma doença na Espanha com exsudação de goma, no século dez; a gomose dos citros teve seu primeiro relato como problema sério nos Azores por volta de 1832, devendo ter-se disseminado gradualmente a outros países. Apesar disso, a primeira elucidação de uma doença em citros causada por um fungo do gênero Phytophthora foi a da podridão parda dos frutos em 1906 (Smith \& Smith, 1906), em consequência de um apoio inicial de $\$ 1.000,00$ oferecido pelo "Lemon Men's Club", da Califórnia, para o estudo dessa doença; mas foi identificado inicialmente como Pythiacystis citrophthora, para ser corrigido para a atual denominação de Phytophthora citrophthora (Leonian, 1925).

Somente em 1914 Phytophthora parasitica foi isolado e identificado (sinônimo na época de $P$. terrestris), de lesões com gomose do tronco na Florida e Cuba (Fawcett, 1915); entretanto apenas em 1918 realizou-se os postulados de Koch, os quais confirmaram está espécie como uma das causadoras dessa doença (Stevens, 1918). 
A partir do cumprimento dos postulados de Koch, confinnando que o gênero Phytophthora era capaz de causar doenças em citros, houve um início de constantes identificações de outras espécies do taxon associados a citros. Em 1920, P. cactorum foi relatado em frutos e em lesões no caule de plantas cítricas nos Estados Unidos (Fawcett, 1920). Nas Filipinas foi isolado e identificado $P$. palmivora afetando plântulas (Reinking, 1921). P. hibernalis foi citado no ano de 1925 , em vários países ao mesmo tempo, na Austrália (Carne, 1925), África do Sul (Doidge, 1925), e Portugal (Maia, 1925). Em 1927, foram identificadas mais duas espécies, a primeira é $P$. citricola a partir de frutos em Taiwan (Sawada, 1927), e a segunda espécie sendo $P$. arecae, a qual afetava folhas e induzia as plantas a um declínio foliar, na Índia (Narasimham, 1927).

Na década de trinta, somente ocorreram três identificações de novas espécies, todas nos Estados Unidos e por Fawcett, sendo a primeira, P. megasperma relatada afetando plântulas, produzindo lesões no caule e podridões em frutos (Fawcett, 1933); e as outras duas espécies foram citadas no ano de 1936 e identificadas como $P$. drechsleri e P. syringae (Fawcett, 1936).

$\mathrm{Na}$ década de quarenta, as três últimas espécies associadas aos citros foram identificadas, duas no mesmo ano P. capsici nos Estados Unidos (Wiant \& Tucker, 1940) e P. cinnamomi no Brasil (Fawcett \& Bitancourt, 1940); as duas associadas à podridão de radicelas. A última espécie foi $P$. boehmeriae afetando frutos com podridão parda na Argentina (Frezzi, 1941).

Interessante é notar alguns fatos como: 1) que após 1950 não tenha sido relatada nenhuma nova espécie associada aos citros, apesar do número de espécies nesse taxon ter aumentado de 43 na década de sessenta (Waterhouse, 1963) para 63 espécies consideradas atualmente (Erwin \& Ribeiro, 1996); 2) mais de $50 \%$ das espécies identificadas associadas aos citros tenham ocorrido nos Estados Unidos.

Explicações para esses fatos poderiam ser: 1) a falta de especialistas no assunto nos diferentes países onde a citricultura está implantada e principalmente nos centros de origem dos citros, onde seriam mais prováveis de encontrar-se um maior número de espécies, assim como da própria variabilidade dos patógenos, por lá ter ocorrido a coevolução patógeno-hospedeiro na associação Phytophthora-Citrus; 2) haveria grandes 
erros de identificações nos trabalhos iniciais, ao ponto do próprio questionamento na década de quarenta, se $P$. cactorum na realidade não seria $P$. citricola (Fawcett \& Bitancourt, 1940), ou mesmo a associação de $P$. citrophthora a plantas daninhas de pomares nos Estados Unidos, quando posteriormente foi confirmada que era $P$. palmivora (Feichtenberger et al., 1984); 3) falta de interesse em estudos de taxonomia e identificação dos isolados de Phytophthora que afetam citros.

Mesmo com as dúvidas, vem sendo consideradas até o presente momento as seguintes espécies associadas aos citros: $P$. parasitica, $P$. citrophthora, $P$. cactorum , $P$. palmivora, $P$. hibernalis, $P$. citricola, $P$. arecae, $P$. megasperma, $P$. drechsleri, $P$. syringae, $P$. capsici, P. cinnamomi e $P$. boehmeriae. Dessas espécies somente as duas primeiras foram identificadas causando todos os diferentes tipos de sintomas relatados para o complexo Phytophthora-Citrus (Erwin \& Ribeiro, 1996), e são também as que predominam no Brasil e no mundo.

\subsubsection{Estudos de espécies de Phytophthora em citros no Brasil}

No Brasil, a primeira descrição da gomose dos citros foi realizada por AvernaSacca (1917), enquanto que a identificação do agente causal foi realizado por Müller (1933), identificando-o como $P$. parasitica. Bitancourt (1936), cita a presença no Brasil de $P$. parasitica, $P$. citrophthora e $P$. palmivora; e em 1940 foi realizada a única identificação no Brasil de uma nova espécie de Phytophthora associada a citros, pela descrição de $P$. cinnamomi em radicelas com podridão (Fawcett \& Bitancourt, 1940).

Em 1942 e 1943, Rossetti (1947) iniciou uma grande avaliação de diferentes seleções de citros, quanto a sua resposta à inoculação na casca por diferentes espécies de Phytophthora, técnica que vem sendo utilizada até o presente momento sem grandes modificações. A autora empregou isolados de 6 espécies do patógeno ( $P$. parasitica, $P$. citrophthora, $P$. palmivora, $P$. cinnamomi, $P$. cactorum e $P$. boehmeriae), dos quais os dois últimos não foram detectados naturalmente até o presente momento no país. $P$. parasitica já era considerado o mais frequentemente detectado nos pomares naquela 
época, mas no experimento em questão somente $P$. citrophthora e $P$. cactorum foram capazes de causarem lesões em 40 das 100 variedades inoculadas.

$\mathrm{Na}$ década de cinquenta ao final da década de setenta, muitos dos trabalhos somente foram realizados na avaliação das respostas dos diferentes genótipos e das combinações copa/porta-enxerto na resposta à inoculação, assim como à influência de doenças, principalmente viróticas ao desenvolvimento de lesões pelo fungo.

Na década de setenta, Rossetti et al. (1972) confirmaram a predominância de $P$. parasitica em isolados obtidos de viveiros e pomares de citros, enquanto $P$. citrophthora estava em torno de $15 \%$ deles; além da caracterização cultural dos mesmos. Nesse mesmo período até a metade dos anos oitenta um grande número de variedades e clones foram avaliados quanto a sua resistência do tecido cambial com diferentes isolados de Phytophthora, sempre avaliando preferencialmente a combinação copa/porta-enxerto, principalmente aproveitando mudas para experimentos de avaliações agronômicas ou ao término dos mesmos.

$\mathrm{Na}$ década de noventa, vem sendo realizados vários trabalhos para avaliar o potencial de controle biológico, com fungos como Trichoderma spp. (May, 1994 e Amorim, 1997), e bactérias como Pseudomonas spp. e Bacillus spp (Amorim, 1997), além da supressividade de fontes de matéria orgânica (Amorim, 1997) e substratos comerciais.

\subsection{Morfologia de Phytophthora}

Todas as espécies de Phytophthora possuem como características: 1) micélio cenocítico; 2) produção de esporângios bem diferenciados do micélio; 3) na liberação dos zoósporos não é produzida nenhuma vesícula; 4) quando produzem estruturas sexuais, produzem um oogônio(feminino) e um anterídio (masculino), os quais são de morfologia bem diferenciada, originando o oósporo (esporo sexual); 5) a fase vegetativa é diplóide, enquanto a haplóide é uma fase muito rápida durante a produção do anterídio e o oogônio. Além do que espécies desse gênero podem sobreviver em solos e materiais 
vegetais em decomposição às custas de suas estruturas vegetativas e reprodutivas, entre as quais incluem-se: micélio, esporângios, zoósporos, cistos, clamidósporos e oósporos.

As hifas são hialinas, ramificadas e sem septos, sendo assim o micélio é denominado de cenocítico; somente produzindo septos verdadeiros quando ocorre a produção de esporos sexuais ou assexuais, entretanto podem surgir alguns quando o micélio torna-se velho, por isso a importância de serem observadas colônias novas para essa característica básica na identificação dos fungos inferiores. Entretanto, a sobrevivência na forma de micélio parece ser muito limitada para esse grupo, devido ao fato de ser facilmente atacado por bactérias do solo, que provocam sua lise.

O diâmetro das hifas é variável de 5 a $8 \mu \mathrm{m}$ e dependente das condições físicas e químicas do meio de cultivo, sendo que elas podem influenciar o aspecto cultural, quando elas são aéreas, superficiais ou imersas no meio. As hifas podem possuir dilatações (hifas "swollen"), ser nodulosas ou tuberculosas, mas raramente crescendo simetricamente. As ramificações nas hifas são próximas a ângulos retos $\left(70\right.$ a $\left.80^{\circ}\right)$ e pode ocorrer uma constrição na base da ramificação, enquanto em Pythium os ângulos são menores, como em Pythium aphadermatum o qual é em torno de $30^{\circ}$ (Ho, 1978). O aspecto visual das colônias não vem sendo usado como critério para diferenciar espécies de Phytophthora (Erwin \& Ribeiro, 1996), apesar de algumas espécies possuírem padrões miceliais típicos, como $P$. porri a qual tem as suas hifas enoveladas.

Ho (1978) propõe uma forma auxiliar de diferenciação pelo tipo de ramificação das hifas apicais ("leading") e pelo número de ramificações, o qual é bem contrastante entre algumas espécies do gênero. As características de padrões culturais em BDA (batata-dextrose-ágar) não vem sendo usadas, apesar de Watherhouse (1983) e Stamps et al. (1990) sugerirem o seu uso, assim como a da ramificação das hifas.

Para o aspecto cultural são denominados de colônias aracnóides, estaloniferas ( $P$. parasitica em BDA), petalóides ( $P$. citrophthora em BDA), rosáceo, estrelado ou cotonoso (sem padrão). Entretanto, Leonian (1934) já detectava variação no aspecto cultural de isolados de diferentes espécies de Phytophthora, apesar de serem originados do mesmo esporo. 
A formação de dilatações nas hifas ("swellings") podem ser em cadeia ou agrupadas, as quais são mais facilmente observadas em culturas líquidas, entretanto a sua função não é bem conhecida, devendo ser relacionada à perpetuação do fungo, semelhantemente aos clamidósporos. Atualmente serve como uma característica auxiliar na diferenciação de algumas espécies (Newhook et al., 1978).

Esporângios desenvolvem-se assexualmente para uma propagação e disseminação rápida. Algumas espécies produzem esporângios facilmente em meio solidificados com ágar, enquanto outras precisam de uma incubação com uma solução aquosa. Eles são originados a partir do esporangióforo, do qual se diferenciam. Em algumas espécies o esporangióforo pode emergir da base de um outro esporângio (simpodial), emergindo somente um é dito simpodial simples e quando são vários é dito composto. Ele ainda pode originar-se de dentro de um esporângio vazio (proliferação interna), ou sair o esporangióforo para fora do esporângio (proliferação externa), sendo estes comportamentos mais comuns nos grupos V e VI, com exceção para $P$. inflata do grupo III (Hall et al., 1992).

Os esporângios podem ser persistentes em algumas espécies (como $P$. parasitica e $P$. citrophthora) ou ser caduco (como $P$. palmivora e $P$. capsici), isto é, o esporângio quebra a ligação com o esporangióforo, ficando uma parte aderida ao esporângio, denominada de pedicelo. A característica de persistência ou caducidade do esporângio é muito importante para a identificação de diferentes espécies, assim como o tamanho do pedicelo, o qual é considerado: curto (menor que $5 \mu \mathrm{m}$ ), médio ou intermediário (entre 5 e $20 \mu \mathrm{m}$ ), e grande (quando maior que $20 \mu \mathrm{m}$ ).

Os zoósporos são biflagelados sendo reniformes a piriformes, possuindo uma depressão longitudinal de um lado, do qual dois flagelos de igual tamanho emergem do mesmo. Sais de lítio podem ser usados para imobilizá-los, sem matá-los; enquanto o seu encistamento pode ser induzido com sais de $\mathrm{Ca}^{2+}$ e $\mathrm{K}^{+}$(Ersek et al., 1991). Por não apresentarem parede celular possuem período de vida muito curto e são os propágulos do fungo mais vulneráveis, mas os mais importantes pela sua capacidade de dispersão pela água. 
Clamidósporos são esporos assexuais que se limitam das hifas por um septo e que apresentam uma parede celular, sendo que a espessura dela é que vai determinar a maior ou menor capacidade de sobrevivência desse esporo no solo, sendo de importância na identificação de algumas espécies.

Os oósporos são os esporos sexuais do fungo, também denominados esporos de dormência. Esses esporos apresentam capacidade de germinação muito baixa. Oósporos formados em uma estação podem genninar após vários períodos de dormência, contribuindo assim para a permanência do fungo no solo por longos períodos, sendo que algumas espécies não produzem estas estruturas, ou necessitam de condições muito especiais, ou mesmo pareamento com isolados de "mating type" complementar, o qual dificulta a identificação de muitas espécies.

\subsection{Taxonomia do gênero Phytophthora}

Grande número de espécies de Phytophthora são conhecidas, sendo que Watherhouse (1963) as agrupa em seis grupos, os quais são mantidos até o momento, já que o sétimo grupo de Stamps et al. (1990) é das espécies marinhas, atualmente pertencentes ao gênero Halophytophthora (Ho \& Jong, 1990); este último grupo vem acumulando algumas novas evidências que as relacionam mais com Pythium do que com Phytophthora.

A classificação de novas espécies de Phytophthora vem aumentando desde o início do século. Watherhouse (1963) citou 43 espécies; Stamps et. al. (1990) já considerava 51 espécies, e recentemente Erwin \& Ribeiro (1996) descreveram 63.

Tucker (1931) enfatizou a importância das características esporângiais e gametângiais como critérios taxonômicos, além das temperaturas cardinais, especialmente a ótima e máxima, considerando somente 17 taxons; mas também a necessidade do uso de critérios fisiológicos na classificação de Phytophthora (Leonian, 1934). Entretanto, um dos maiores problemas para o estudo de espécies de Phytophthora reside na sua taxonomia (Luz \& Matsuoka, 1996). Os critérios usados na sistemática do gênero são 
quase todos baseados em características morfológicas e fisiológicas, estabelecidas em diferentes arranjos que pretendem dar um formato mais ou menos definido para $o$ agrupamento e individualização das espécies. As tentativas de organizar e melhor definir a sistemática do gênero ainda não solucionaram alguns problemas graves, podendo serem divididos quanto à indução de estruturas fúngicas; à variação morfológica; à existência de espécies heterotálicas ou estéreis e à necessidade de testes fisiológicos. Sendo os resultados obtidos nem sempre precisos ou dificeis de realizar. Atualmente as técnicas moleculares servirão como um grande auxilio na confirmação das identificações, evitando erros grosseiros como muitas vezes ocorrem, mesmo quando são pareceres de institutos de renome na identificação de fungos.

Como foi citado anteriormente o gênero Phytophthora é subdividido atualmente em seis grupos taxonômicos (Erwin \& Ribeiro, 1996), como inicialmente já tinha sido proposto por Watherhouse (1963) e Stamps et al. (1990). Esse agrupamento intragenêrico baseia-se na morfologia do esporângio e da inserção do anterídio no oogônio. Quando possuem esporângios: papilados (grupo I e II); semipapilados (grupo III e IV) e não papilados (grupo V e VI); e quando possuem ou predominam os anterídios paráginos (grupo I, III e V) ou anfigenos (grupo II, IV e VI). Assim conseguese separar os grupos por essas duas características, embora a produção de estruturas não seja fácil e muitas vezes há necessidade de acumular uma série de informações, fazendose necessário a comparação com outras características contidas nas descrições gerais (Stamps et al., 1990 e Erwin \& Ribeiro, 1996).

Associados a citros temos: $P$. cactorum do grupo I; $P$. parasitica, $P$. citrophthora $P$. palmivora, $P$. arecae, $P$. capsici e $P$. boehmeriae do grupo II, $P$. citricola e $P$. syringae do grupo III, $P$. hibernalis do grupo IV, $P$. megasperma do grupo $\mathrm{V}$, e do grupo VI $P$. drechsleri e $P$. cinnamomi.

Do grupo I, $P$. cactotum, foi a segunda espécie a ser descrita no gênero Phytophthora em 1886, 10 anos depois de $P$. infestans (Zentmeyer, 1983), mas somente em 1920 associado aos citros. Como características possui anterídio parágino e com esporângios distintamente papilados e frequentemente eles são formados em grupos. Os esporângios normalmente são terminais e ocasionalmente intercalares, sendo caducos 
com pedicelos curtos (menos de $4 \mu \mathrm{m}$ ). As dimensões dos esporângios variam de 19 - 73 x 16 - $46 \mu \mathrm{m}$ com uma relação comprimento/largura de 1.2 a 1.45. Os clamidósporos nem sempre são produzidos por todos os isolados variando de 14 a $56 \mu \mathrm{m}$, com média entre 25 e $35 \mu \mathrm{m}$. A temperatura máxima é de $31^{\circ} \mathrm{C}$, a ótima de $25^{\circ} \mathrm{C}$ e a mínima de 2 ${ }^{\circ} \mathrm{C}$ (Erwin \& Ribeiro, 1996).

Do grupo II, há seis espécies associadas aos citros que possuem características em comum, como a produção de esporângios papilados e anterídeo do tipo anfigeno. As espécies $P$. parasitica, $P$. citrophthora, $P$. palmivora, $P$. arecae, $P$. capsici e $P$. boehmeriae, são descritas rapidamente a seguir. Neste grupo II ou grupo da "palmivora" da chave de Waterhouse (Stamps et al., 1990) estão $P$. parasitica e $P$. citrophthora que são as espécies mais encontradas nas regiões produtoras de citros do Brasil e do mundo.

$P$. parasitica $(=P$. nicotianae $)$ foi associada aos citros em 1914. O termo $P$. parasitica vem sendo adotado pelas publicações citrícolas, apesar que pelo Código Internacional de Nomenclatura Botânica o nome correto seria $P$. nicotianae, por ter sido com esse nome a sua primeira descrição. Como características morfológicas possui anterídios anfigenos mas pode apresentar paráginos e com esporângios distintamente papilados. Os esporângios normalmente são terminais, ou com inserção lateral e ocasionalmente intercalares, sendo persistentes. As dimensões dos esporângios variam de 26 - $60 \times 18-40 \mu \mathrm{m}$ com uma relação comprimento/largura de 1.1 a 1.5. Os clamidósporos são terminais ou intercalares variando de 13 a $60 \mu \mathrm{m}$. A temperatura máxima é de 35 a $40{ }^{\circ} \mathrm{C}$, a ótima de $28^{\circ} \mathrm{C}$ e a mínima de $5{ }^{\circ} \mathrm{C}$ (Erwin \& Ribeiro, 1996).

P. citrophthora associada aos citros em 1906, o qual não produz estruturas sexuais em meio de cultura, e acredita-se que seu sistema sexual seja mais complexo do que o sistema A1/A2. Os esporângios normalmente são papilados, terminais mas ocasionalmente podem ser laterais ou intercalares. Morfologicamente os esporângios variam nas suas formas, podendo ser visualizados como esféricos, ovóides, obpiriformes, obturbinados ou elipsóides. As dimensões dos esporângios estão na faixa de 23 - 90 x 18 - $60 \mu \mathrm{m}$ com médias de 45 - $30 \mu \mathrm{m}$, e com uma relação comprimento/largura de 1.2 a 2.0. Os clamidósporos raramente ocorrem em isolados de citros os quais oscilam entre 25 
e $35 \mu \mathrm{m}$. A temperatura máxima é de 32 a $33{ }^{\circ} \mathrm{C}$, a ótima de 22 a $28{ }^{\circ} \mathrm{C}$ e a mínima menor do que $5{ }^{\circ} \mathrm{C}$ (Erwin \& Ribeiro, 1996).

$P$. palmivora possui esporângios bem variáveis morfologicamente podendo ser elípticos a ovóides, com papilas proeminentes e os esporangióforos estão na forma simpodial, podendo-se encontrar até 20 por simpódio. Eles são caducos com pedicelos curtos $(5 \mu \mathrm{m})$. As dimensões dos esporângios variam de $40-60 \times 25-35 \mu \mathrm{m}$, e com uma relação comprimento/largura de 1.4 a 2.0. Os clamidósporos variam de 32 a $42 \mu \mathrm{m}$. A temperatura máxima é de $35^{\circ} \mathrm{C}$, a ótima de 27 a $30^{\circ} \mathrm{C}$ e a mínima de $11^{\circ} \mathrm{C}$ (Erwin \& Ribeiro, 1996).

P. arecae com esporângios distintamente papilados, variando do elipsóide, obturbinado até esférico. Os esporângios são caducos com pedicelos curtos de 1 a $6 \mu \mathrm{m}$. As dimensões dos esporângios variam de $20-72 \times 20-48 \mu \mathrm{m}$ com uma relação comprimento/largura de 1.1 a 1.6, com média de 1.37 . Os clamidósporos variam de 18 a $60 \mu \mathrm{m}$ com paredes usualmente com $1 \mu \mathrm{m}$ de espessura. A temperatura máxima é de 35 ${ }^{\circ} \mathrm{C}$, a ótima de 27 a $30^{\circ} \mathrm{C}$ e a mínima de 10 a $12{ }^{\circ} \mathrm{C}$ (Erwin \& Ribeiro, 1996).

P. capsici com esporângios papilados, mas em certos casos são semi-papilados, com abertura variando de 1.4 a $9.2 \mu \mathrm{m}$ e podendo ocorrer de 2 a 3 ápices. As formas variam segundo as condições culturais, variando morfologicamente de subesféricos, ovóide, obovóide, elipsóide, fusiforme, piriforme a formas distorcidas. Os esporângios são caducos, fechados na base ("tapered") e com longos pedicelos variando de 35 a 138 $\mu \mathrm{m}$. As dimensões dos esporângios variam de 32 - 65 x 17 - $38 \mu \mathrm{m}$ com uma relação comprimento/largura de 1.4 a 2.1 (Erwin \& Ribeiro, 1996).

P. boehmeriae com esporângios papilados, variando do esféricos, elipsóides, ovóides ou obturbinados. Os esporângios são caducos com pedicelos curtos com menos de $5 \mu \mathrm{m}$. As dimensões dos esporângios variam de 28 - 69 × 20 - $51 \mu \mathrm{m}$ com uma relação comprimento/largura de 1.0 a 1.6, com média de 1.37. Os clamidósporos não são frequentes e variam de 26 a $51 \mu \mathrm{m}$ com media de $41 \mu \mathrm{m}$ com paredes com $2 \mu \mathrm{m}$ de 
espessura. A temperatura máxima é de $35^{\circ} \mathrm{C}$, a ótima de 27 a $30^{\circ} \mathrm{C}$ e a mínima de 10 a $12^{\circ} \mathrm{C}$ (Erwin \& Ribeiro, 1996).

Há somente duas espécies do grupo III associadas aos citros que possuem como características em comum, a produção de esporângios semipapilados e anterídeo do tipo parágino. As espécies são $P$. citricola e $P$. syringae.

$P$. citricola possui esporângios bem variáveis morfologicamente podendo ser obovóides, obclavados e obpiriformes, podendo ter bifurcações profundas com duas papilas ou ainda de forma irregular com 3 ou 4 lóbulos. Os esporângios são persistentes os quais variam nas suas dimensões de 30 - 75 × 21 - $44 \mu \mathrm{m}$ com uma média de 47 × 34 $\mu \mathrm{m}$, e com uma relação comprimento/largura de 1.4. Os clamidósporos são raros. A temperatura máxima é de $31^{\circ} \mathrm{C}$, a ótima de 25 a $28^{\circ} \mathrm{C}$ e a mínima de $3^{\circ} \mathrm{C}$ (Erwin $\&$ Ribeiro, 1996).

$P$. syringae é uma espécie de clima temperado e é homotálica, os esporângios variando morfologicamente, podendo ser ovóides ou obpiriformes. Eles são persistentes e as suas dimensões podem ser de 24 - 39 x 19 - $51 \mu \mathrm{m}$, e com uma relação comprimento/largura de 1.32 a 1.85 . Os clamidósporos não são produzidos. A temperatura máxima é de 23 a $25^{\circ} \mathrm{C}$, a ótima de 15 a $20^{\circ} \mathrm{C}$ e a mínima é menor que $5^{\circ} \mathrm{C}$ (Erwin \& Ribeiro, 1996).

Do grupo IV somente $P$. hibernalis está associada aos citros e foi nela que ocorreu a sua primeira descrição da espécie, que possui como características do grupo a produção de esporângios semipapilados e anterídeo do tipo anfigeno, apesar de poder ser parágino nesta espécie. $P$. hibernalis possui esporângios bem variáveis morfologicamente podendo ser alongados, elipsóides, ovóides ou obovóides, com os esporangióforos podendo ser um simpódio irregular. Eles são caducos com pedicelos longos com 23 a $73 \mu \mathrm{m}$ de comprimento. As dimensões dos esporângios variam de 29 $53 \times 14-22 \mu \mathrm{m}$, com uma média $40 \times 19 \mu \mathrm{m}$, e com uma relação comprimento/largura de 2.1. Os clamidósporos não são formados. A temperatura máxima é menor que $25^{\circ} \mathrm{C}$, a ótima de $15^{\circ} \mathrm{C}$ e a mínima menor que $5^{\circ} \mathrm{C}$ (Erwin \& Ribeiro, 1996). 
Do grupo V somente $P$. megasperma é descrita associada aos citros que possui como características do grupo a produção de esporângios não papilados e anterídeo do tipo parágino. P. megasperma possui esporângios que variam morfologicamente podendo ser ovóides ou obpiriformes. Eles são persistentes e com proliferação interna, variando nas suas dimensões de $35-60 \times 25-45 \mu \mathrm{m}$, com uma média de $41 \times 28 \mu \mathrm{m}$, e com uma relação comprimento/largura de 1.5. Não são produzidos clamidósporos. A temperatura máxima é menor que $33^{\circ} \mathrm{C}$, a ótima de 20 a $25^{\circ} \mathrm{C}$ e a mínima menor que $5^{\circ} \mathrm{C}$ (Erwin \& Ribeiro, 1996).

Do grupo VI há duas espécies associadas aos citros que possuem características em comum, como a produção de esporângios não papilados e anterídeo do tipo anfigeno. As espécies são $P$. drechsleri e $P$. cinnamomi.

$P$. drechsleri possui esporângios em simpódio simples, sendo bem variáveis morfologicamente podendo ser obpiriformes para ovóides até alongados, com proliferação interna e externa. Eles são persistentes e variam de $24-38 \times 15-24 \mu \mathrm{m}$, com uma média de $31 \times 21 \mu \mathrm{m}$, com uma relação comprimento/largura de 1.6. Somente em alguns isolados há presença de clamidósporos que variam de 4.2 a $11 \mu \mathrm{m}$. A temperatura máxima é de $37^{\circ} \mathrm{C}$, a ótima de 28 a $31^{\circ} \mathrm{C}$ e a mínima de $5^{\circ} \mathrm{C}$ (Erwin \& Ribeiro, 1996).

P. cinnamomi possui esporângios bem variáveis morfologicamente podendo serem ovóides, obpiriformes ou elipsóides, sendo produzidos por proliferação interna ou externa, ou pelo desenvolvimento simpodial a partir da região basal de um esporângio vazio. Eles são persistentes e as dimensões deles variam de $11-123 \times 11-63 \mu \mathrm{m}$, e com uma relação comprimento/largura de 1.3 a 1.9. Os clamidósporos são abundantes em meio de cultura e variam de 31 a $50 \mu \mathrm{m}$. A temperatura máxima é de 32 a $34{ }^{\circ} \mathrm{C}$, a ótima de 24 a $28^{\circ} \mathrm{C}$ e a mínima de 5 a $6{ }^{\circ} \mathrm{C}$ (Erwin \& Ribeiro, 1996).

Os dados moleculares serão uma ferramenta de grande valia para retirar parte da subjetividade na identificação de fungos e para auxiliar os menos especializados. Entretanto, são as características morfológicas e fisiológicas que devem reger o auxilio dessas ferramentas que tanto estão incentivando a sistemática nos últimos anos. 


\subsection{Variabilidade em fungos fitopatogênicos}

Os estudos de variabilidade de fungos fitopatogênicos estavam inicialmente restritos à caracterização morfológica, cultural e de respostas a diversos produtos químicos, os quais foram de grande importância para o desenvolvimento das primeiras normas na identificação de espécies. $\mathrm{O}$ aumento na informação sobre os comportamentos ao nível fisiológico e da interação com os hospedeiros levou à necessidade de novas formas de diferenciação, como o emprego de plantas indicadoras; para poder diferenciar as respostas de grupos de organismos dentro da mesma espécie, e descobrir melhor as relações entre o patógeno e o hospedeiro na sua coevolução.

Fenótipos de compatibilidade vegetativa (CV) também vem sendo amplamente usados para estimar diversidade dentro de populações fúngicas, por essa característica não sofrer nenhuma pressão de seleção. A evidência fenotípica da incompatibilidade vegetativa é detectada pelo aparecimento de zonas de inibição ("barrage zone") quando estirpes incompatíveis são acondicionadas opostamente em placas de Petri com meio de cultura, na qual ocorre o crescimento das colônias independentemente, sem ocorrerem fusão entre elas (Anagnostakis, 1992).

Assim, é dito que a estrutura genética de uma população é resultante de interações complexas entre fatores intrínsecos que promovem ou contrastam a similaridade genética entre grupos de indivíduos (fluxo de genes, deriva genética e seleção natural). O fluxo de genes promovendo a dispersão dos variantes; a deriva genética pela fixação aleatória ou combinação dos variantes e a seleção natural pelo favorecimento dos variantes melhor adaptados aos nichos ecológicos (Egger, 1992).

A necessidade de evidenciar as diferenças intraespecíficas sempre esbarraram na dificuldade de obter diferenças entre os vários grupos e mesmos entre indivíduos da mesma espécie. $O$ desenvolvimento de técnicas que minimizam o efeito ambiental foram de grande importância, entre as quais podemos citar as que evidenciam as diferenças ao nível das isoenzimas e as que detectam as diferenças ao nível de DNA.

$\mathrm{O}$ estudo de populações de fungos sempre teve dificuldades pela falta de marcadores e pelo grande efeito ambiental sobre a expressão fenotípica de muitos deles. 
Entre os marcadores usados para revelar a estrutura das populações foram empregados os alelos do "mating-type", de virulência e os de incompatibilidade vegetativa.

$\mathrm{O}$ uso de isoenzimas foi a primeira ferramenta a trazer evidências da variabilidade genética intraespecífica em fungos, e em várias espécies de Phytophthora vem sendo empregada com esse fim (Oudemans \& Coffey, 1991). A característica de codominância foram de grande valia para o estudo de alguns cruzamentos realizados no gênero, mas sempre com pequeno número de híbridos, pela sua dificuldade de produção.

\subsection{Resistência a fungicidas}

O uso de produtos químicos é uma medida que geralmente será empregada no controle de doenças em plantas, porque em muitas situações é determinante na garantia da colheita e na estabilidade da produção (Kimati, 1995). Além do que, em algumas espécies do gênero Phytophthora essas medidas são vitais para a sobrevivência da cultura agrícola, quando em condições favoráveis à ocorrência das doenças.

Os fungicidas sistêmicos inibem seletivamente processos metabólicos específicos de grupos de fungos sensíveis e ao mesmo tempo, com uma baixa fitotoxicidade. Os fungos por meio de mutações, podem tornar-se resistentes aos produtos, requerendo um manejo efetivo, para um maior tempo de vida útil do princípio ativo e similares, evitando a resistência cruzada.

As consequências do desenvolvimento de populações de fungos resistentes a fungicidas podem ser desastrosas tanto para o agricultor, que pode perder a sua produção pela ineficiência do fungicida, quanto para o fabricante, que investiu grandes montas de dinheiro no desenvolvimento do produto. Genótipos mutantes resistentes a fungicidas sistêmicos podem surgir numa proporção de 1 em $10^{9}$ e 1 em $10^{4}$ em mutações espontâneas e induridas, respectivamente, embora em condições de laboratório consigam-se mutantes resistentes a todos os fungicidas sistêmicos testados. A adaptabilidade do mutante e a pressão de seleção são os principais fatores na estabilidade do mutante e na sua predominância nas populações. A adaptabilidade do mutante depende fundamentalmente do gene ou genes que sofreram mutação para resistência, 
consequentemente se os genes antes da mutação eram importantes condicionadores de competitividade (por exemplo, patogenicidade, capacidade de esporulação ou sobrevivência), então o mutante terá sua capacidade adaptativa diminuída.

A adaptabilidade do mutante possui estreita correlação com a forma de ação do fungicida, de modo que mutantes mais adaptados surgem com maior facilidade para determinados princípios ativos. As evidências mostram que fungicidas como as acylalaninas (metalaxyl) e os benzimidazóis (benomyl) apresentam alto risco de falhas pelo surgimento de resistência, ao passo que para triazóis, imidazóis e morfinas a segurança é maior pela dificuldade no surgimento de mutantes resistentes.

Os oomicetos são altamente insensíveis a benzimidazóis, carboxamidas e aos inibidores da biossíntese de esteróis (como os triazóis); consequentemente houve necessidade da produção de princípios ativos específicos a eles, sendo quatro os principais: propamocarb, cymoxanil, metalaxyl e efosite. O metalaxyl apresenta alta toxicidade, afetando a esporulação e o desenvolvimento do micélio fúngico, sendo sensível em concentrações menores do que 10 ppm, mas há grande número de relatos de resistência a esse fungicida, até mesmo no gênero Phytophthora.

Até 1970, devido à predominância dos fungicidas protetores não específicos, os casos de resistência relatados limitavam-se a menos de 10 gêneros de fungos. Em 1980, coincidindo com a escalada dos fungicidas sistêmicos, esse número já ascendia a aproximadamente 35 gêneros (Delp, 1980) e mais de 60 gêneros em 1988 (Eckert, 1988).

\subsection{Técnicas moleculares no estudo de patógenos de plantas}

As características das técnicas desejadas são: 1) número suficiente de marcas facilmente detectadas; 2) eficiente método de análise para grande número de indivíduos; $\mathrm{e}$ 3) as marcas devem ser estáveis. Entre as técnicas que tornaram-se disponíveis podemos citar: isoenzimas, RFLP, DNA mitocondrial, DNA ribossômico, PCR e RAPD.

A técnica de isoenzimas consiste na deteç̧ão de diferenças de migração entre enzimas com mesma função, em géis não desnaturantes, no qual são adicionadas as 
substâncias e mantidas as condições químicas e físicas necessárias para a mediação da reação das enzimas em estudo; consequentemente produzindo um composto visível, para detecção do local de migração das proteínas. Essa técnica permitiu uma análise rápida de grande número de amostras e possui sensibilidade para detectar variações dentro de populações (Paccola-Meirelles et al., 1988). Entretanto, está sujeita a variações do ambiente, à idade do micélio ou à estrutura fúngica que está sendo amostrada; sendo limitada a sua detecção a regiões do genoma que codificam proteínas; mas muitas vezes elas não são suficientemente variáveis para análise de populações clonais.

O polimorfismo no comprimento de fragmentos de restrição ou RFLP, é uma técnica baseada na quebra do DNA em sequências específicas (palindrômicas) reconhecidas por enzimas de restrição, as quais clivam o DNA do mesmo, segundo a distribuição das sequências reconhecidas. Essas sequências clivadas variam no número de pares de nucleotídeos. Previamente, são selecionadas sequências clivadas e clonadas de um banco genômico ou cDNA (sondas), que ligam-se especificamente a uma única ou poucas regiões do DNA total clivado durante o processo de hibridização. As diferenças dos tamanhos das sequências hibridizadas com a sonda é que vai determinar a detecção do polimorfismo. O princípio da detecção de polimorfismo por minisatélites (sinônimo de VNTR- sequências adjacentes que se repetem em número variável) é o mesmo que aquele do RFLP. A diferença entre as duas técnicas é a seleção da sonda, enquanto que a sonda RFLP hibridiza apenas com uma ou poucas sequências do genoma, as sondas para minisatélites hibridizam com sequências altamente repetitivas no genoma, revelando grande número de fragmentos com peso molecular diferente (Ferreira \& Grattapaglia, 1995).

A técnica de PCR que utiliza temperaturas limites para evitar a ligação não específica entre sequências do DNA e dois oligonucleotídeos, um no início e o outro na região final da sequência em trans a ser detectada. Para a amplificação de uma sequência específica do genoma, há necessidade de estudos prévios para detecção e sequenciamento da mesma para determinar os nucleotídeos que constituirão os oligonucleotídeos iniciadores (Ferreira \& Grattapaglia, 1995). Ela é extremamente importante para diagnóstico e para genes altamente sequenciados como os ribossômicos. 
O estudo do DNA mitocondrial é realizado porque o tamanho do genoma mitocondrial é pequeno ao ponto de poder ser estudado facilmente por RFLP, não necessitando do demorado processo de seleção de sondas como ocorre no estudo de genomas totais de fungos, plantas e animais. $\mathrm{O}$ rearranjo dos genes e o tamanho do genoma é muito estável com a maioria da variação ocorrendo na sequência de nucleotídeos em animais; entretanto em fungos o rearranjo dos genes é variável, e a variação no tamanho é extensivo entre taxons intimamente relacionados. Havendo várias publicações aplicadando o estudo de RFLP do DNA mitocondrial a Phytophthora (Föster, et al., 1989 e Carter et al. 1990).

\subsection{Marcadores moleculares}

Os marcadores moleculares são os dados necessários para os estudos de genética inicialmente e consequentemente inúmeras outras áreas empregarão estas informações para um melhor entendimento das diversas visões micro- e macroespacial. Atualmente o termo marcadores moleculares vem sendo generalizado para marcadores genéticos, mas devemos ter como conceito que o primeiro é todo e qualquer fenótipo molecular oriundo de um gene expresso ou de um segmento de DNA, enquanto que somente poderá ser denominado de marcador genético quando se verificar o seu comportamento de acordo com as leis de Mendel (Ferreira \& Grattapaglia, 1995).

O surgimento de novas técnicas que fornecem marcadores de DNA, vem mudando a forma de visão de análise dos genótipos dos organismos, obtendo-se as mudanças ou modificações existentes no DNA, para depois determinar as suas implicações; recebendo denominação de genética genômica (Berckmann, 1988), e a cada dia está aumentando a sua força, o qual pode ser detectado pelo grande número de trabalhos com marcadores moleculares, com um mínimo de outros dados fenotípicos para comparação. 


\subsection{RAPD (Polimorfismo de DNA amplificado ao acaso)}

Técnica desenvolvida por dois grupos independentemente nos Estados Unidos (Willians et. al., 1990 e Welsh \& McClellans, 1990) fundamentada na técnica da PCR, a qual é baseada na amplificação de regiões do DNA onde ocorre a complementação com um oligonucleotídeo sintético ("primer"), escolhido arbitrariamente e sem conhecimento da genética do organismo em estudo. A duplicação ocorre porque utiliza-se uma DNA polimerase termoestável (Taq DNA polimerase). As regiões que possuem locais para o anelamento dos oligonucleotídeos podem sofrer dois tipos de amplificação, ou linear ou exponencial. A amplificação linear ocorre devido que ao duplicar a região do DNA existem somente regiões complementares de um só lado da fita, subsequentemente os oligonucleotídeos não se ligam à nova fita duplicada, ao não servir de molde todas serão originadas apenas do DNA inicial; obtendo-se no final do processo de amplificação em torno de 40 cópias, os quais não são detectados. A amplificação exponencial ocorre quando existem sequências complementares aos oligonucleotídeos nas duas fitas do DNA a ser amplificado, assim as fitas de DNA duplicadas serviram de molde conjuntamente com o DNA inicial, tendo no final da reação em torno de 500 bilhões de cópias, as quais serão detectadas e analisadas facilmente após a sua corrida em um gel de agarose e evidenciação do DNA amplificado pelo brometo de etídio.

Outras vantagens dessa técnica são a não utilização de radioatividade e a fase inicial para a obtenção de dados ser relativamente rápida, além do seu custo, que deverá baixar à medida que ocorra uma diminuição no preço da enzima, pelo produção em grande escala (Ferreira \& Grattapaglia, 1995).

Essa técnica vem sendo empregada amplamente em citros, desde o estudo de diferenciação de clones (Machado et al., 1996), o estudo de bactérias endofíticas (Araújo, 1996) e patógenos fúngicos como Colletotrichum gloeosporioides (Izioka, 1995) e Guignardia citricarpa (Glienke, 1995). 


\subsection{RAPD em patógenos de plantas}

O seu principal triunfo para o estudo de microrganismos patogênicos é sem dúvida a não necessidade de um conhecimento detalhado da genética do patógeno, porque isso ocorre na maioria deles; além de se obter grande número de bandas amplificadas, as quais não sofrem influência do ambiente, servindo como marcadores para outros estudos subsequentes de grande importância nas áreas de genética, sistemática, epidemiologia e controle de patógenos.

A cada dia que passa maior é o número de patógenos que vem sendo estudados com o auxilio dessa técnica, com os mais variados objetivos. O estudo de outras espécies de Phytophthora também está ocorrendo (Cooke et al., 1996), mas deve-se utilizar a combinação de técnicas simples e clássicas, com as novas técnicas moleculares para atingir melhores resultados e uma compreensão maior dos próprios resultados obtidos por elas.

As aplicações com fungos patogênicos começou pela necessidade de diferenciação de isolados, devido a subjetividade e condições de cultivo apropriadas para caracterização de isolados, assim como da fidelidade das linhagens e culturas monospóricos de micotecas do mundo.

Ao conseguir visualizar grupos de isolados pelas técnicas de agrupamento, principalmente por dendrogramas esta técnica comę̧ou a ser empregada visando distinguir entre isolados (Vasconcelos, et al., 1994), estirpes não agressivas, raças (Crowhurst et al., 1991) e espécies(Cooke et al., 1996). Alguns conseguiram a diferenciação enquanto outros não.

O terceiro passo está sendo estimar a diversidade existente entre as populações do patógenos desde microespaços até macroespaços, para detenninar a capacidade adaptativa e principalmente a migração desses microrganismos . Esse objetivo está levando ao questionamento das formas de análise atuais sugerindo novas técnicas estatísticas específicas para esse fim.

A aplicação mais importante parece que será a determinação da importância das diferentes formas de esporos produzidas pelos patógenos na ocorrência das doenças 
(McDonald \& Martinez, 1990), para o qual a hipótese de patógenos clonais e os com capacidade de reprodução sexual serão de grande importância para um melhor entendimento das implicações da diversidade gênica.

Estudos de ondas de migração de Phytophthora infestans (Fry et al, 1993 e Goodwin, et al., 1994) vem sendo realizados com outras técnicas que poderiam também ser realizadas por RAPD, como foi feito com fungos entomopatogênicos (Hajek et al., 1996). Revisões sobre aplicações está saturando as principais revistas de todas as áreas de estudo da vida, e atualmente estão fixando-se na aplicação e métodos de análise, entretanto os estudos de populações, como os atuais que estão sendo realizados para $P$. infestans devem começar para a maioria dos patógenos de grande importância econômica.

Apesar de ser de caráter dominante, a técnica de RAPD se apresenta como uma ferramenta de grande utilidade para o mapeamento de fungos fitopatogênicos, por serem na sua maioria haplóides. No caso dos diplóides, como Phytophthora e as ferrugens, as análises dos cruzamentos pela técnica do "pseudo-testcross", auxiliará no mapeamento, como está sendo realizado em plantas perenes como Eucalyptus (Grattapaglia et al., 1995) e Citrus (Cristofani, 1997). 


\section{MATERIAL E MÉTODOS}

\subsection{Microrganismos}

Os isolados que deram origem às culturas monozoospóricas de Phytophthora parasitica, utilizados neste trabalho, foram gentilmente cedidos pelo pesquisador Eduardo Feichtenberger; eles pertencem à coleção do Laboratório Regional de Sorocaba do Instituto Biológico de São Paulo. Os materiais a partir dos quais foram isolados as estirpes originais do trabalho, faziam parte do material enviado para detecção do patógeno a essa instituição. Os isolados com as suas respectivas procedências e culturas monospóricas que deram origem encontram-se na Tabela 1. A distribuição dos isolados na região citrícola do Estado é apresentada na Figura 1.

Tabela 1 . Isolados originais, procedência no Estado de São Paulo e denominação das culturas monozoospóricas de $P$. parasitica.

\begin{tabular}{ccc}
\hline Cultura & Local & Denominação \\
\hline P. parasitica & Exp. podridão & IAC 01/95 \\
P. parasitica & Exp. podridão & IAC 02/95 \\
LRS 52/92 & Limeira & IAC 03/95 \\
& & IAC 04/95 \\
LRS 04/94 & Taubaté & IAC 06/95 \\
& & IAC 10/95 \\
LRS 34/93 & Limeira & IAC 07/95 \\
& & IAC 08/95 \\
& & IAC 09/95 \\
LRS 39/92 & Jales & IAC $11 / 95$ \\
LRS 37/93 & Laranjal Paulista & IAC 12/95 \\
LRS 30/93 & Itapetininga & IAC 13/95 \\
LRS 47/94 & Araras & IAC $14 / 95$ \\
LRS 23/93 & Conchal & IAC $15 / 95$ \\
& & IAC $16 / 95$ \\
& & IAC 17/95 \\
\hline
\end{tabular}

* Obtidos de misturas de isolados usados nos experimentos de avaliação de resistência a Phytophthora no Programa de melhoramento de porta-enxertos de citros do Centro de Citricultura Sylvio Moreira - IAC, em parceria com o Instituto Biológico de São Paulo 


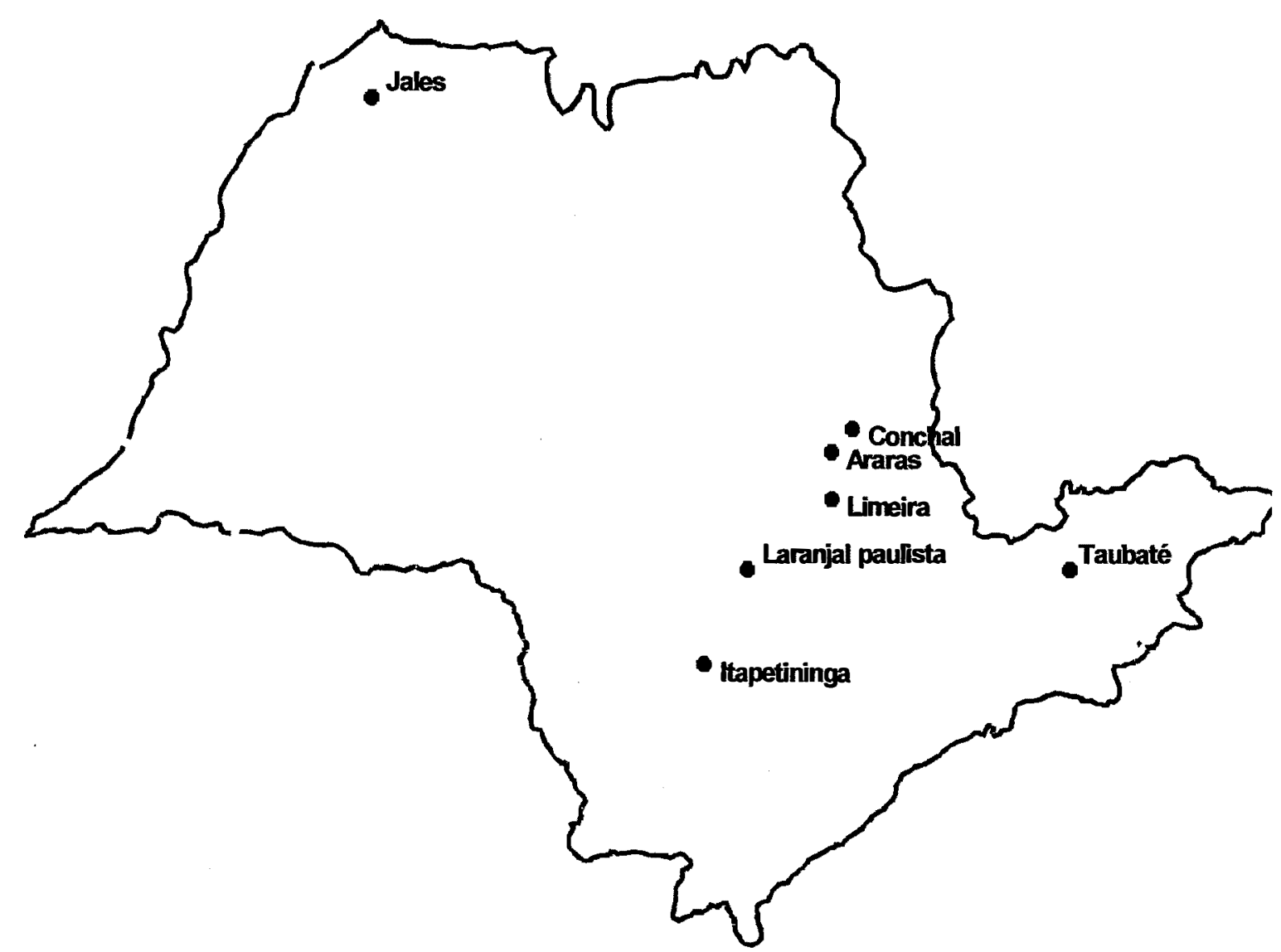

Figura 1 - Localização das culturas originais dos isolados de Phytophthora, no mapa do Estado de São Paulo.

O isolado de Guignardia citricarpa IAC 13/96 (anamórfico Phyllosticta citricarpa), um ascomiceto que foi utilizado como um controle de uma espécie considerada não ser afetada pelo metalaxyl, nas avaliações de determinação de biótipos resistente a esse fungicida específico para oomicetos. Ele foi isolado de lesões em frutos de limão verdadeiro (Citrus limon) da Região de Conchal, os quais eram sintomas típicos da Mancha Preta dos Citros, doença que atingiu níveis epidêmicos em 1995 e 1996. 


\subsection{Meios de cultura}

\subsubsection{Meio Cenoura Dextrose Ágar (CDA)}

$-200 \mathrm{~g}$ de cenoura nova

$-20 \mathrm{~g}$ de dextrose

$-20 \mathrm{~g}$ de ágar

- $1000 \mathrm{ml}$ de água destilada

A cenoura foi picada e colocada no liquidificador, na máxima velocidade por aproximadamente 1 minuto, junto com $1000 \mathrm{ml}$ de água destilada. A seguir foi filtrada em gaze, e adicionados a dextrose e o ágar, completando-se novamente o volume para 1000 ml. Autoclavou-se por 20 minutos a $120^{\circ} \mathrm{C}$ e 1 atm. $\mathrm{O}$ meio foi preparado para a manutenção das colônias.

\subsubsection{Meio Cenoura Ágar (CA)}

- $200 \mathrm{~g}$ de cenoura nova

- $1000 \mathrm{ml}$ de água destilada

- $20 \mathrm{~g}$ de ágar

A cenoura foi colocada no liquidificador na máxima velocidade por aproximadamente 1 minuto e a seguir filtrada em gaze. Adicionou-se o ágar e autoclavou-se por 20 minutos a $120^{\circ} \mathrm{C}$ e $1 \mathrm{~atm}$.

O meio foi preparado para a manutenção das colônias, obtenção de culturas monozoospóricas e caracterização morfológica dos isolados.

\subsubsection{Meio Cenoura}

- $200 \mathrm{~g}$ de cenoura

- $1000 \mathrm{ml}$ de água destilada 
O modo de preparo foi avaliado para determinar a melhor forma para realizar a extração de DNA do micélio fúngico, os quais foram os seguintes:

\subsubsection{Com liquidificador}

Colocou-se a cenoura no liquidificador na máxima velocidade por aproximadamente 1 minuto, até ficar bem cortada. Filtrou-se com gaze. Autoclavou-se por 20 minutos a $120^{\circ} \mathrm{C}$ e 1 atm. Utilizou-se para a produção de micélio na extração de DNA.

\subsubsection{Por fervura}

Picou-se a cenoura em pedaços bem pequenos e finos, adicionando-se em um recipiente com a água destilada e foi aquecido, quando iniciou fervura foi desligado o fogo. Filtrou-se com quatro gazes. Autoclavou-se por 20 minutos a $120^{\circ} \mathrm{C}$ e $1 \mathrm{~atm}$. $\mathrm{O}$ seu uso foi para a produção de micélio para a extração de DNA.

\subsection{Manutenção das culturas estoques}

As culturas dos diferentes isolados, originais e monozoospóricos foram inicialmente crescidas em meio cenoura - ágar (CA). Após o crescimento, discos de ágar contendo micélio foram retirados das bordas das colônias e transferidos para tubos de vidro de penicilina, contendo água estéril, para conservação a temperatura ambiente. A renovação das culturas estoque foi realizada a cada seis meses, pela transferência dos discos em água, para o meio CA visando o seu crescimento e posterior conservação. 


\subsection{Soluções e tampões}

3.4.1 Solução de PVL (Dhingra \& Sinclair, 1985)
Álcool de polivinil
$1.66 \mathrm{~g}$
Água
$10 \mathrm{ml}$
Ácido láctico
$10 \mathrm{ml}$
Glicerina
$1 \mathrm{ml}$

Dissolveu-se o álcool de polivinil com a água, agitou-se vagarosamente e subsequentemente adicionou-se o ácido láctico e a glicerina. Foi usado para fazer as lâminas a fim de se observar as estruturas dos isolados e realizar as respectivas mensuraç̃es na caracterização morfológica dos isolados.

3.4.2. Tampão de extração de DNA

$\begin{array}{ll}\text { EDTA } 0.5 \mathrm{M} \mathrm{pH} 8,0 & 0.5 \mathrm{ml} \\ \text { SDS } 10 \% & 1.0 \mathrm{ml} \\ \mathrm{NaCl} 1 \mathrm{M} & 2.5 \mathrm{ml} \\ \text { Tris } \mathrm{HCl} 1 \mathrm{M} & 2.0 \mathrm{ml} \\ \mathrm{H}_{2} \mathrm{O} \text { milliQ } & 4.0 \mathrm{ml}\end{array}$

As soluções foram previamente autoclavadas, e o preparo do tampão foi na hora do seu uso.

3.4.3. Solução de acetato de potássio (p/ $100 \mathrm{ml})$

Acetato de potássio $0.5 \mathrm{M}$

Ac. acético glacial

$\mathrm{H}_{2} \mathrm{O}$ milliQ
$60.0 \mathrm{ml}$

$11.5 \mathrm{ml}$

$28.5 \mathrm{ml}$

Autoclavou-se a solução para o seu uso. 
3.4.4. Solução de fenol saturado (adaptado de Sambrook et al., 1989)

Fenol $\quad 50 \mathrm{~g}$
Tris $-\mathrm{HCl}(0,2 \mathrm{M}, \mathrm{pH} 8,0)$

Solubilizou-se $50 \mathrm{~g}$ de fenol cristalizado em banho-maria e adicionou-se o mesmo volume do tampão Tris - $\mathrm{HCl}(0,2 \mathrm{M}, \mathrm{pH} 8,0)$. Agitou-se por pelo menos 30 minutos para equilibrar o $\mathrm{pH}$, e deixou-se em repouso para retirar a fase aquosa. Novamente adicionou-se o mesmo volume do tampão repetindo-se o processo até a fase fenólica atingir $\mathrm{pH} 8,0$, após o qual foi retirada a fase aquosa e adicionado um volume do tampão Tris - $\mathrm{HCl}$ suficiente para cobrir a solução de fenol com uma camada de mais de $2 \mathrm{~cm}$ de espessura, para evitar a sua volatilização: $O$ seu armazenamento foi realizado em geladeira, usando-se frasco escuro. Todo esse procedimento foi realizado em capela.

3.4.5. Solução de RNAse

$\begin{array}{lr}\text { RNAse } & 10 \mathrm{mg} \\ \text { Tris }-\mathrm{HCl} 1 \mathrm{M} \mathrm{pH} \mathrm{8,0} & 10 \mu \mathrm{l} \\ \mathrm{NaCl} 1 \mathrm{M} & 15 \mu \mathrm{l} \\ \mathrm{H}_{2} \mathrm{O} \text { destilada (q.s.p.) } & 1000 \mu \mathrm{l}\end{array}$

3.4.6. Tampão TE

$\begin{array}{lr}\text { Tris } \mathrm{HCl} \quad 1 \mathrm{M} \mathrm{pH} \mathrm{8,0} & 1 \mathrm{ml} \\ \text { EDTA } 0.5 \mathrm{M} & 0.2 \mathrm{ml} \\ \mathrm{H}_{2} \mathrm{O} \text { destilada (q.s.p.) } & 100 \mathrm{ml}\end{array}$


3.4.7. Tampão TAE $50 \mathrm{X}$

Tris base

Ac. acético glacial

EDTA $0.5 \mathrm{M}$ (pH 8.0)
$242 \mathrm{~g}$

$57,1 \mathrm{ml}$

$100 \mathrm{ml}$

3.4.8. Tampão TAE $1 \mathrm{X}$

Tampão TAE 50 X

$20 \mathrm{ml}$

Água destilada (q. s. p.)

$1000 \mathrm{ml}$

3.4.9. Gel de agarose $(0,8 \%)$

Agarose

Tampão TAE $1 \mathrm{X}$

$0,8 \mathrm{~g}$

$100 \mathrm{ml}$

3.4.10. Gel de agarose $(1,4 \%)$

Agarose

Tampão TAE $1 \mathrm{X}$
$1,4 \mathrm{~g}$

$100 \mathrm{ml}$

3.4.11. Tampão de corrida

Azul de bromofenol

$0.25 \mathrm{~g}$

Xileno cianol

$0.25 \mathrm{~g}$

Ficol

$15.0 \mathrm{~g}$

Água destilada (q. s. p.) 
3.4.12. Solução de brometo de etídio (1\%)

$\begin{array}{ll}\text { Brometo de etídio } & 100 \mathrm{mg} \\ \text { Água destilada } & 10 \mathrm{ml}\end{array}$

$\mathrm{O}$ brometo de etídio foi dissolvido em água destilada por agitação $\mathrm{e}$ posteriormente armazenada no refrigerador. No momento do uso $5 \mu \mathrm{ml}$ desta solução foi misturada a $100 \mathrm{ml}$ de água.

\subsubsection{Solução de dNTP's}

Os 4 dNTP's (Pharmacia) foram adquiridos numa concentração de $100 \mathrm{mM}$. Para uso os dNTP's foram misturados e diluídos em água de modo a se obter uma concentração estoque de $2,5 \mathrm{mM}$ de cada dNTP's.

3.4.14. Solução tampão para a reação de amplificação por RAPD

Tampão 10 X (Pharmacia)

dNTP $2,5 \mathrm{mM}$

Primer $4 \mathrm{mM}$

$\mathrm{MgCl}_{2} 50 \mathrm{mM}$

Taq DNA polimerase $(5 \mathrm{U} / \mu \mathrm{l})$

DNA (10 $\mathrm{ng} / \mu \mathrm{l})$

$\mathrm{H}_{2} \mathrm{O}$ milli Q (q.s.p.)
$2.5 \mu 1$

$2.0 \mu \mathrm{l}$

$2.5 \mu 1$

$1.5 \mu 1$

$0.4 \mu 1$

$2.0 \mu \mathrm{l}$

$25.0 \mu 1$

O tampão 10X (Pharmacia) é constituído de $\mathrm{KCl} 500 \mathrm{mM}, \mathrm{MgCl}_{2} 15 \mathrm{mM}$ e TrisHCl $100 \mathrm{mM} \mathrm{pH} \mathrm{9.0,} \mathrm{consequentemente} \mathrm{a} \mathrm{solução} \mathrm{tampão} \mathrm{para} \mathrm{a} \mathrm{reação} \mathrm{de} \mathrm{amplificação}$ possui $4.5 \mathrm{mM}$ de $\mathrm{MgCl}_{2}$. 
3.4.15. Solução de 10.000 ppm de metalaxyl

$\begin{array}{ll}\text { Apron } & 2,86 \mathrm{~g} \\ \text { Água estéril (q.s.p.) } & 100 \mathrm{ml}\end{array}$

A solução foi mantida em banho maria a $90{ }^{\circ} \mathrm{C}$ por 20 minutos antes da sua utilização.

\subsection{Obtenção de culturas monozoospóricas}

\subsubsection{Indução de produção e liberação de zoósporos}

Os isolados foram crescidos em meio CA (item 3.2.2.), confirmada a presença de esporângios após o seu crescimento em luz contínua por pelo menos 10 a 15 dias, a temperatura ambiente. Adicionou-se água esterilizada nas placas $(10 \mathrm{ml})$, e estas foram ao refrigerador por duas horas (choque térmico para estímulo e sincronização das divisões). A seguir, as placas foram retiradas e deixadas a temperatura ambiente por $30 \mathrm{a}$ 60 minutos. Durante esse período de tempo ocorre a formação dos zoósporos por mitoses, denominado de clivagem citoplasmática por não ocorrer a formação de parede celular durante as divisões.

\subsubsection{Diluições sucessivas}

Pipetou-se $100 \mu$ da solução contendo zoósporos e misturou-se sucessivamente com $900 \mu \mathrm{l}$, realizando diluições sucessivas, das quais $100 \mu \mathrm{l}$ foram pipetados e adicionados em placas com meio CA, adicionou-se água esterilizada quando necessário, para um melhor espalhamento na placa, devido não poder ser usada alça de Drigalski.

Realizou-se a retirada das colônias ditas monozoospóricas das placas que apresentavam colônias bem definidas e isoladas, tendo menos de 10 colônias por placa. 


\subsection{Manutenção da patogenicidade dos isolados}

A manutenção da patogenicidade dos isolados foi realizada pela metodologia a seguir:

- Coletou-se ramos de plantas produtivas de citros com $1 \mathrm{~cm}$ de diâmetro.

- Lavou-se com água e limpou-se bem a superfície para melhor eficiência ao realizar-se a desinfecção superficial dos ramos.

- Cortaram-se os ramos em pedaços de 8 a $10 \mathrm{~cm}$ de comprimento.

- Realizou-se a desinfecção superficial em fluxo laminar ( 2 minutos em álcool e 10 minutos em hipoclorito de sódio $2 \%$ ).

- Com o auxílio de um furador de rolha, de diâmetro interno de 0,8 cm e flambado previamente, retirou-se discos de casca dos ramos desinfetados.

- Acondicionou-se os discos de casca, com a superfície externa em contato com o meio ágar - água a $2 \%$.

- Retirou-se discos de micélio da bordas de colônias de Phytophthora, com diâmetro menor que $0,6 \mathrm{~cm}$. O disco foi acondicionado sobre a superfície interna dos discos da casca.

- Acondicionou-se a $25^{\circ} \mathrm{C}$ e esperou-se o desenvolvimento da lesão nos discos da casca.

- Retirou-se os discos de casca que foram a seguir acondicionados em meio CA com 100 ppm de benomyl, para a recuperação do fungo que teve que passar pelo tecido hospedeiro para ser reisolado.

Esse procedimento foi realizado antes do inicio da extração do DNA, para confirmar a capacidade de provocar lesões nos tecidos dos hospedeiros.

\subsection{Caracterização morfológica dos isolados de Phytophthora}

Para caracterização morfológica foram utilizadas culturas monozoospóricas crescidas em meio CA durante 20 a 25 dias, a $28^{\circ} \mathrm{C}$ e fotoperíodo de $12 \mathrm{~h}$. Foi retirado um pequeno fragmento do micélio do fungo da região central das colônias (micelio mais 
velho), com a menor quantidade de meio de cultura, onde pode-se encontrar esporângios maduros. Para cada isolado foram montadas três lâminas semipermanentes, fixadas com PVL (item 3.4.1.); sendo que em cada lâmina duas lamínulas foram montadas.

As determinações consistiram na medição do comprimento e largura de dez esporângios através de uma ocular com escala micrométrica, previamente determinado o coeficiente de correção para a determinação das medidas em $\mu \mathrm{m}$. $\mathrm{O}$ delineamento do experimento foi inteiramente casualizado com 10 repetições, foram realizadas a análise de variância e a estimativa dos quadrados médios, para comparar os isolados e determinar a variância genética $\mathrm{e} o \mathrm{~h}^{2}$. A identificação das espécies a qual os isolados pertenciam, foi pela análise dos dados obtidos e seguindo os passos da chave de identificação. A mesma foi produzida pela síntese de outras chaves gerais produzidas para a identificação de espécies de Phytophthora (Anexo 1).

\subsection{Caracterização cultural dos isolados de Phytophthora}

Em Phytophthora a aparência das colônias em meio de cultura sólido é uma característica auxiliar na confirmação das espécies, assim foi avaliado o tipo de morfologia no crescimento cultural dos isolados, sendo comparados com a da literatura especializada (Stamps et al., 1990 e Erwin \& Ribeiro, 1996).

\subsection{Taxas de crescimento dos isolados a $37^{\circ} \mathrm{C}$}

Os isolados foram crescidos a $37{ }^{\circ} \mathrm{C}$ em meio cenoura ágar (CA), para a determinação das curvas de crescimento pela medição do diâmetro das colônias e servir como características complementares na identificação da espécie de Phytophthora, isoladas de citros e cedidas pelo Instituto Biológico de São Paulo.

O experimento foi conduzido inteiramente casualizado com três repetições e a seguir realizada a análise de variância, para tentar comparar as taxas de crescimentos dos isolados nessa condição. 


\subsection{Determinação do efeito do metalaxyl}

Usou-se o produto comercial Apron da Ciba-Geigy Química S.A. , o qual possui 350 gramas de metalaxyl por $1 \mathrm{~kg}$ do produto comercial (35\%). Da solução estoque de $10.000 \mathrm{ppm}$ (item 3.4.15.) foi realizada mais duas diluições das quais foi retirada $1.0 \mathrm{ml}$ para cada $100 \mathrm{ml}$ de meio CA, para obtermos a concentração final de 100 ppm; 10 ppm e 1 ppm de metalaxyl, respectivamente. No controle não foi adicionado qualquer solução com fungicida. A taxa de crescimento micelial foi determinada medindo-se o diâmetro das colônias.

O experimento foi um fatorial $4 \times 16$ e conduzido em delineamento inteiramente casualizado com 3 repetições e incubadas as placas a $25^{\circ} \mathrm{C}$.

\subsection{Determinação das equações das curvas de crescimento}

As curvas de crescimento foram ajustadas para o modelo linear para poder obter e comparar as taxas de crescimento entre os diferentes isolados fúngicos.

\subsection{Produção do micélio fúngico}

A produção da massa micelial para a extração do DNA dos isolados foi obtida em meio líquido cenoura (item 3.2.3), das seguintes formas.

3.12.1. A partir de discos de meio CA com micélio sem agitação

A produção de micélio, na fase inicial de adaptação da metodologia, foi realizada em frascos Erlenmeyer de $250 \mathrm{ml}$, contendo $50 \mathrm{ml}$ de meio cenoura-dextrose (item 3.2.1.), inoculado com 3 a 5 discos contendo micélio fúngico, retirado das bordas de colônias crescidas previamente em meio CDA. Os frascos foram incubados a temperatura ambiente com agitação diária manual, por mais de 14 dias. 
3.12.2. A partir de discos de meio com micélio com agitação

Utilizou-se frascos Erlenmeyer de $250 \mathrm{ml}$, contendo $50 \mathrm{ml}$ de meio cenoura (item 3.2.3.2), inoculado com 3 a 5 discos de meio contendo micélio fúngico, retirado das bordas de colônias crescidas previamente em meio CA (item 3.2.2.). Os frascos foram incubados a $28^{\circ} \mathrm{C}$ em "shaker" em rotação de $100 \mathrm{rpm}$, por mais de 14 dias.

3.12.3. A partir de inoculação de zoósporos no meio

Indução de zoósporos nas colônias com mais de 15 dias, como descrito no item 3.5.1., do qual foram retiradas aliquotas de $500 \mu \mathrm{l}$ e adicionados em placas de Petri de $10 \mathrm{~cm}$, contendo meio cenoura, obtido por dois métodos diferentes, para a comparação do efeito das diferentes formas de preparo do meio (itens 3.2.3.1. e 3.2.3.2).

3.12.3.1. Cenoura triturada em liquidificador

Esse meio foi produzido como descrito no item 3.2.3.1.; no qual há grande quantidade de pigmentos liberados pela cenoura (carotenos).

\subsubsection{Cenoura fervida}

Esse meio foi produzido como descrito no item 3.2.3.2.; no qual é mínima a liberação de pigmentos no meio.

\subsection{Extração de DNA}

A extração do DNA a partir do micélio fúngico foi realizado pela metodologia descrita a seguir: 
- Filtrou-se o meio líquido contendo o micélio fúngico, por meio de um papel de filtro, pela produção de vácuo em um frasco de Kitassato. $\mathrm{O}$ micélio foi produzido como descrito no item 3.12. O micélio foi lavado com água, destilada e autoclavada, para retirar o excesso de meio.

- O micélio foi transferido com o auxilio de uma pinça flambada para um almofariz previamente autoclavado.

- Adicionou-se $\mathrm{N}_{2}$ líquido no almofariz e com o auxilio de um pilão macerou-se o micelio até virar pó.

- Com o auxilio de uma espátula flambada, transferiu-se o micélio pulverizado para tubos autoclavados, realizando-o rapidamente devido ao pó tornar-se viscoso a medida que vai descongelando.

- Adicionou-se $10 \mathrm{ml}$ da solução de extração e incubou-se por 30 a 60 minutos a $60^{\circ} \mathrm{C}$.

- Adicionou-se 4,5 ml da solução de acetato de potássio (item 3.4.3), mantendo-se em gelo por 1 hora.

- Centrifugou-se por 10 minutos a $10.000 \mathrm{rpm}$ a $4{ }^{\circ} \mathrm{C}$.

- Filtrou-se o sobrenadante por meio de gaze previamente autoclavada.

- Adicionou-se ao sobrenadante 2 volumes de etanol e manteve-se a $-20^{\circ} \mathrm{C}$ por uma noite.

- Centrifugou-se por 20 minutos a $10.000 \mathrm{rpm}$ a $4{ }^{\circ} \mathrm{C}$.

- Despejou-se o sobrenadante e inverteu-se os tubos para secar o etanol.

- Resuspendeu-se em $1 \mathrm{ml} \mathrm{de} \mathrm{TE} \mathrm{(item} \mathrm{3.4.6.).}$

- Adicionou-se $500 \mu \mathrm{l}$ em Eppendorf de $1500 \mu \mathrm{l}$, e adicionou-se $500 \mu \mathrm{l}$ de fenol (item 3.4.4.). Agitou-se em vortex e centrifugou-se a 10.000 rpm por 5 minutos.

- Retirou-se a fase superior com o auxilio de uma micropipeta, evitando retirar a fase intermediária, a qual contém proteínas. A fase aquosa retirada foi acondicionada em outro Eppendorf ao qual foi adicionado $500 \mu \mathrm{l}$ de fenol - clorofồrmio (1:1). Agitou-se novamente em vortex. .

- Centrifugou-se a $10.000 \mathrm{rpm}$ por 5 minutos. 
- Transferiu-se a fase superior para outro Eppendorf, adicionando $2,5 \mu \mathrm{l}$ da solução de RNAase (3.4.5).

- Incubou-se a $37^{\circ} \mathrm{C}$ por 1 hora.

- Adicionou-se $500 \mu \mathrm{l}$ de clorofồrmio e agitou-se novamente, centrifugou-se a $10.000 \mathrm{~g}$ por 5 minutos.

- Retirou-se a fase superior e transferiu-se para outro Eppendorf no qual adicionou-se 2 volumes de etanol para precipitar o DNA, deixando-se por um mínimo de 24 horas a -20 ${ }^{\circ} \mathrm{C}$.

- Centrifugou-se a $10.000 \mathrm{rpm}$ por 10 minutos, eliminando o sobrenadante.

- Secou-se as amostras no interior dos Eppendorfs e ressuspendeu-se em TE.

\subsection{Integridade do DNA}

Preparou-se um gel de agarose de $0.8 \%$ como descrito no item 3.4.9.; $5 \mu l$ de cada extração foram usadas para a determinação da integridade, o qual foi misturado com o tampão de corrida. A eletroforese foi realizada a $90 \mathrm{~V}$ por 2 horas, e posteriormente, o gel foi corado em uma solução de brometo de etídio, como descrito no item 3.4.12.

\subsection{Quantificação do DNA}

A quantificação do DNA foi realizada pela diluição de 200 vezes em $\mathrm{H}_{2} \mathrm{O}$, a partir de $5 \mu$ da solução de DNA de cada isolado e a leitura foi feita em espectrofotometro a um comprimento de onda $(\lambda)$ de $260 \mathrm{~nm}$. O espectrofotometro utilizado foi o modelo U3300 da Hitachi. O branco foi a água destilada usada para diluir a aliquota do DNA de cada isolado. Após a leitura todos os DNAs foram diluídos para $10 \mathrm{ng} / \mu \mathrm{l}$. 


\subsection{Otimização da técnica de RAPD}

As condições da amplificação foram realizadas em um termociclador da Hermed Parket, com as seguintes temperaturas durante os 40 ciclos da reação:

desnaturação a $92{ }^{\circ} \mathrm{C}$ por 90 segundos; anelamento a $37^{\circ} \mathrm{C}$ por 60 segundos e extensão a $72{ }^{\circ} \mathrm{C}$ por 120 segundos.

Todos os Eppendorfs de $500 \mu$ l eram novos e após a adição da mistura de reação com o DNA dos isolados foi adicionado uma gota de óleo mineral, para não ocorrer evaporação da solução durante a amplificação.

A otimização da mistura para amplificação foi referente à quantidade da enzima Taq DNA polimerase e a quantidade de DNA dos isolados, as demais foram mantidas constantes (item 3.4.14.). O gel de agarose para a separação dos fragmentos de DNA amplificados foi de $1.4 \%$ (item 3.4.10.).

\subsubsection{Atividade da enzima Taq polimerase}

Inicialmente foi tentado a otimização da enzima Taq DNA polimerase, realizandose a amplificação com $0.5 \mathrm{U} ; 1.0 \mathrm{U} ; 1.5 \mathrm{U}$ e $2.0 \mathrm{U}$ da enzima nos 25 ul da reação.

\subsubsection{Quantidade de DNA}

A determinação da quantidade de DNA em ng para a realização da amplificação foi realizada duas vezes. Na primeira vez, foi realizado com $20 \mathrm{ng} ; 40 \mathrm{ng} ; 60 \mathrm{ng}$ e $100 \mathrm{ng}$ de DNA utilizando-se o isolado IAC01/95 com 3 oligonucleotídeos diferentes, os quais eram o OPE - 02; OPE - 03 e o OPE - 07, suas sequências estão na Tabela 2.

$\mathrm{Na}$ segunda determinação foram empregadas as seguintes quantidades de $10 \mathrm{ng}$; $20 \mathrm{ng} ; 40 \mathrm{ng} ; 60 \mathrm{ng} ; 80 \mathrm{ng}$ e $100 \mathrm{ng}$ do DNA dos isolados IAC01/95 e IAC02/95. Os oligonucleotídeos foram OPE - 06; OPE - 15 e OPE - 18, suas sequências estão na Tabela 2. 
Tabela 2 - Oligonucleotídeos iniciadores utilizados na otimização na quantidade de DNA necessária para a amplificação pela técnica de RAPD, com as suas respectivas sequências de bases e percentagem de bases CG na sua constituição.

\begin{tabular}{ccc}
\hline Oligonucleotídeos & Sequência de bases & $\%$ CG \\
\hline OPE - 02 & GGTGCGGGAA & 70 \\
OPE - 03 & CCAGATGCAC & 60 \\
OPE - 06 & AAGACCCCTC & 60 \\
OPE - 07 & AGATGCAGCC & 60 \\
OPE - 15 & ACGCACAACC & 60 \\
OPE - 18 & GGACTGCAGA & 60 \\
\hline
\end{tabular}

\subsubsection{Seleção de oligonucleotídeos}

Na seleção dos oligonucleotídeos para a avaliação do polimorfismo pelo RAPD, foi realizado um teste preliminar pela amplificação do DNA do isolado IAC01/95 com 36 oligonucleotídeos diferentes, os quais são listados no Tabela 3, com suas respectivas sequências e conteúdo de CG (\%). 
Tabela 3 - Triagem de oligonucleotídeos iniciadores para a posterior avaliação do polimorfismo dos isolados por RAPD, com as suas respectivas sequências de bases e percentagem de bases CG na sua constituição.

\begin{tabular}{|c|c|c|}
\hline Oligonucleotídeos & Sequência de bases & $\% \mathrm{CG}$ \\
\hline OPE - 01 & CCCAAGGTCC & 70 \\
\hline OPE - 02 & GGTGCGGGAA & 70 \\
\hline OPE - 03 & CCAGATGCAC & 60 \\
\hline OPE - 04 & GTGACATGCC & 60 \\
\hline OPE - 05 & TCAGGGAGGT & 60 \\
\hline OPE - 06 & AAGACCCCTC & 60 \\
\hline OPE - 08 & TCACCACGGT & 60 \\
\hline OPE - 09 & CTTCACCCGA & 60 \\
\hline OPE - 10 & CACCAGGTGA & 60 \\
\hline OPE - 11 & GAGTCTCAGG & 60 \\
\hline OPE - 12 & TTATCGCCCC & 60 \\
\hline OPE - 13 & CCCGATTCGG & 70 \\
\hline OPE - 14 & TGCGGCTGAG & 70 \\
\hline OPE - 15 & ACGCACAACC & 60 \\
\hline OPE - 16 & GGTGACTGTG & 60 \\
\hline OPE - 17 & CTACTGCCGT & 60 \\
\hline OPE - 18 & GGACTGCAGA & 60 \\
\hline OPE - 19 & ACGGCGTATG & 60 \\
\hline OPE - 20 & AACGGTGACC & 60 \\
\hline OPX - 01 & CTGGGCACGA & 70 \\
\hline OPX - 02 & TTCCGCCACC & 70 \\
\hline OPX - 03 & TGGCGCAGTG & 70 \\
\hline OPX - 04 & CCGCTACCGA & 70 \\
\hline OPX - 05 & ССТТТСССТC & 60 \\
\hline OPX - 06 & ACGCCAGAGG & 70 \\
\hline OPX - 07 & GAGCGAGGCT & 70 \\
\hline OPX - 08 & CAGGGGTGGA & 70 \\
\hline OPX - 09 & GGTCTGGTTG & 60 \\
\hline OPX - 11 & GGAGCCTCAG & 70 \\
\hline OPX - 12 & TCGCCAGCCA & 70 \\
\hline OPX - 13 & ACGGGAGCAA & 60 \\
\hline OPX - 14 & ACAGGTGCTG & 60 \\
\hline OPX - 15 & CAGACAAGCC & 60 \\
\hline OPX - 16 & CTCTGTTCGG & 60 \\
\hline OPX - 17 & GACACGGACC & 70 \\
\hline OPX - 18 & GACTAGGTGG & 60 \\
\hline
\end{tabular}




\subsection{RAPD dos isolados de $P$. parasitica}

A amplificação dos isolados foi realizada com a solução de reação apresentada no item 3.4.14., após a otimização das variáveis da reação. Dos oligonucleotídeos testados no item 3.16.3. foram escolhidos ao acaso oito, dentro dos que amplificaram o DNA do isolado IAC $01 / 95$, para assim determinar a variabilidade genética dos isolados de $P$. parasitica de citros.

Tabela 4 - Oligonucleotídeos iniciadores utilizados na detecção de polimorfismo entre isolados, com as respectivas sequências de bases e percentagem de bases CG na sua constituição.

\begin{tabular}{ccc}
\hline Oligonucleotídeos & Sequência de bases & $\%$ CG \\
\hline OPE - 03 & CCAGATGCAC & $60 \%$ \\
OPE - 08 & TCACCACGGT & $60 \%$ \\
OPE - 16 & GGTGACTGTG & $60 \%$ \\
OPE - 19 & ACGGCGTATG & $60 \%$ \\
OPX - 04 & CCGCTACCGA & $70 \%$ \\
OPX - 07 & GAGCGAGGCT & $70 \%$ \\
OPX - 09 & GGTCTGGTTG & $60 \%$ \\
OPX - 12 & TCGCCAGCCA & $70 \%$ \\
\hline
\end{tabular}

\subsection{Análise das bandas amplificadas por RAPD}

Os pesos moleculares foram obtidos pela determinação do log da migração das bandas amplificadas pela técnica de RAPD e o consequente uso da regressão linear obtida do log da migração das bandas de peso molecular conhecido ( $\lambda$ clivado com a Hind III), como sugerido para proteínas por Alfenas et al. (1991).

Os dados obtidos foram codificados para 1 ou 0 , para presença ou ausência de um determinado fragmento de DNA no gel. Cada banda ou fragmento foi considerado ser um locus para as análises de similaridade genética. 
3.18.1. Análise entre indivíduos

A proporção de loci polimórficos das bandas amplificadas pela técnica de RAPD foi realizada segundo McDonald \& Martinez (1990):

$$
\begin{aligned}
& \mathrm{P}=\mathrm{x} / \mathrm{r} \\
& \mathrm{x}=\text { número de bandas ou loci polimórficos } \\
& \mathrm{r}=\text { número total de bandas ou loci }
\end{aligned}
$$

A similaridade genética entre os isolados foi calculada pelo índice de Jaccard, o qual é indicado para dados binários ou quando padrões de bandas não podem ser estudados em termos de genótipos ou alelos. Ele é determinado pela divisão do número de fragmentos comuns entre dois indivíduos e a soma de todos os fragmentos obtidos para os dois indivíduos comparados, como é apresentado a seguir:

$$
\text { Similaridade }\left(S_{j}\right)=\left(N_{A B}\right) /\left(N_{A}+N_{B}+N_{A B}\right)
$$

Em que

$\mathrm{N}_{\mathrm{AB}} \quad$ - Número de fragmentos de DNA comuns aos isolados A e B

$\mathrm{N}_{\mathrm{A}} \quad$ - Número de fragmentos de DNA somente encontrados no isolado $\mathrm{A}$

$\mathrm{N}_{\mathrm{B}} \quad$ - Número de fragmentos de DNA somente encontrados no isolado B

A matriz das similaridades foram agrupados pela técnica UPGMA para a subsequente produção do dendrograma, para uma visualização das possíveis relações entre os diferentes isolados, de uma forma de análise hierárquica. 


\section{RESULTADOS E DISCUSSÃO}

\subsection{Reativação da patogenicidade dos isolados de $P$. parasitica}

Todos os isolados tiveram capacidade de provocar lesões em discos de cascas destacadas de variedades susceptíveis. Isso evidência dois fatos, o primeiro que todos os isolados estudados são patógenos potenciais, pela sua capacidade de provocar lesões quando inoculados em tecidos hospedeiros susceptíveis; o segundo foi que as repicagens sucessivas não foram suficientes para levar à perda da capacidade de colonizar tecidos hospedeiros, como é muitas vezes relatado na literatura para muitos patógenos.

Esse passo no trabalho tinha por objetivo evitar a perda da patogenicidade dos isolados, além do que sempre é sugerido a passagem do patógeno pela planta hospedeira, pelo menos uma vez por ano após repicagens sucessivas ou antes de serem empregados em estudos de resistência de plantas ou caracterização morfológica ou cultural dos mesmos.

\subsection{Caracterização morfológica dos isolados de $P$. parasitica}

Todos os isolados estudados apresentam esporângios papilados (Tabela 5), característica que os enquadra nos grupos I ou II do gênero Phytophthora, no qual estão 7 das 13 espécies associadas aos citros, como pode-se verificar pelo Anexo 1 .

Os esporângios de todas as culturas foram predominantemente persistentes (Tabela 5), entretanto houve alguns esporângios caducos (Figura 2) em dois isolados (IAC 01/95 e IAC 17/95), isso possivelmente deve-se por que alguns esporangióforos podem quebrar, não por uma deiscência natural mas por algum mecanismo físico durante o próprio preparo das lâminas; esse parecer é suportado pela grande variação do comprimento do pedicelo nos esporângios caducos (Ho, 1981), como pode ser visto na Tabela 5. A característica de esporângios persistentes leva à identificação de todos os isolados serem ou $P$. parasitica ou $P$. citrophthora (Anexo 1), os quais são as duas 
espécies desse gênero fúngico mais importantes e predominantes no mundo, que encontram-se associadas a citros.

Tabela 5 . Caracterização dos esporângios nos isolados de $P$. parasitica em meio cenoura - ágar (CA).

\begin{tabular}{|c|c|c|c|c|c|}
\hline \multirow[t]{2}{*}{ Isolado } & \multirow{2}{*}{$\begin{array}{c}\text { Papilado } \\
\text { poro estreito }\end{array}$} & \multirow{2}{*}{ pemipapilado } & \multirow{2}{*}{$\frac{\text { Não-papilado }}{\text { poro largo }}$} & \multicolumn{2}{|c|}{ Esporângio } \\
\hline & & & & Caduco & Persistente \\
\hline IAC $01 / 95$ & + & - & - & $+(\mathrm{P}$ e $\mathrm{M})$ & $t$ \\
\hline IAC 02 / 95 & + & - & - & - & + \\
\hline IAC $03 / 95$ & + & - & - & - & + \\
\hline IAC 04 / 95 & + & - & - & - & + \\
\hline IAC $06 / 95$ & + & - & - & - & + \\
\hline IAC 07 / 95 & + & - & - & - & + \\
\hline IAC $08 / 95$ & + & - & - & - & + \\
\hline IAC 09 / 95 & + & - & - & - & + \\
\hline IAC $10 / 95$ & + & - & - & - & + \\
\hline IAC $11 / 95$ & + & - & - & - & + \\
\hline IAC $12 / 95$ & + & - & - & - & + \\
\hline IAC $13 / 95$ & + & - & - & - & + \\
\hline IAC 14 / 95 & + & - & - & _ & + \\
\hline IAC $15 / 95$ & + & - & - & - & + \\
\hline IAC $16 / 95$ & + & - & - & - & + \\
\hline IAC $17 / 95$ & + & - & - & $+(\mathrm{P})$ & + \\
\hline
\end{tabular}

$$
\begin{aligned}
& +=\text { presença } \\
& -=\text { ausência } \\
& P=\text { pedicelo menor que } 5 \mu \mathrm{m} \\
& M=\text { pedicelo entre } 5 \text { e } 20 \mu \mathrm{m} \\
& \mathrm{G}=\text { pedicelo maior que } 20 \mu \mathrm{m}
\end{aligned}
$$




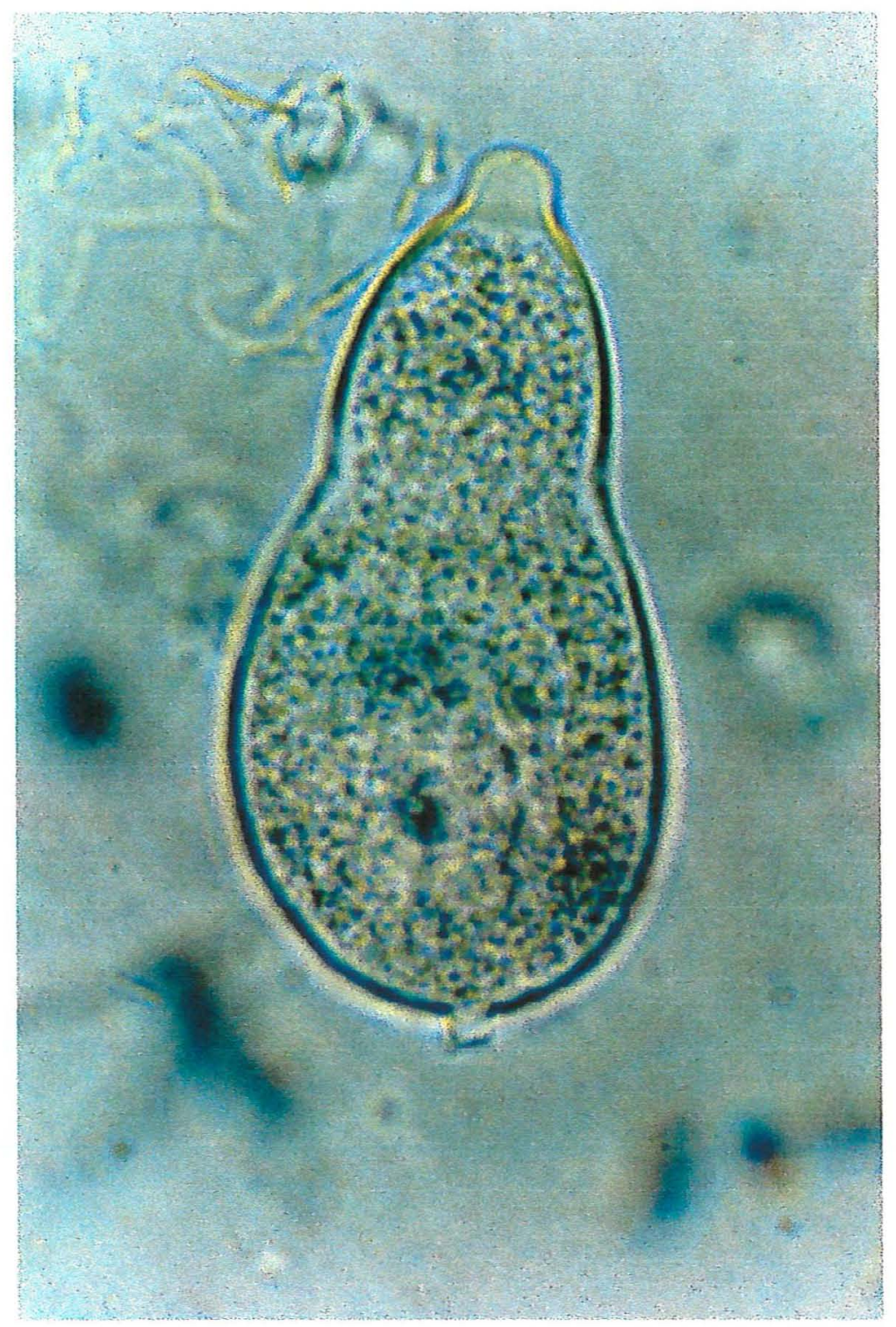

Figura 2 - Esporângio caduco $(51$ x $25 \mu \mathrm{m})$ com pescoço e pedicelo curto $(2 \mu \mathrm{m})$. 
As formas dos esporângios foram predominantemente ovóides e obpiriformes, ocorrendo frequentemente esféricos e em alguns casos foram encontradas formas disformes (Tabela 6 e Figura 3). As formas encontradas para os esporângios foram típicas para as duas espécies predominantes em citros ( $P$. parasitica e $P$. citrophthora), servindo como uma informação adicional de que se tratava de uma dessas espécies ou das duas (Stamps et. al. 1990). As formas disformes eram consideradas típicas de P. citrophthora, as quais não eram relatadas para $P$. parasitica, entretanto como atualmente $P$. parasitica é sinônimo de $P$. nicotianae esses tipos de morfologia dos esporângios podem ser consideradas como possíveis de serem encontrados, não servindo para diferenciar essas duas espécies (Erwin \& Ribeiro, 1996). O isolado IAC 13/95 produziu grande número de esporângios disformes, o qual evidência que ele apresenta as maiores diferenças morfológicas em relação aos demais isolados; enquanto nos outros isolados como o IAC 14/95 e o IAC 15/95, por terem apresentado somente alguns esporângios disformes o fato pode ter ocorrido por uma variação natural na morfologia dos mesmos.

As dimensões dos esporângios foram tomadas e são apresentadas as médias do comprimento, largura e relação comprimento/largura na Tabela 7. Houve diferenças estatisticamente significativas nas condições estudadas para as dimensões dos esporângios, sendo essas diferenças significativas entre locais de isolamentos, e mesmo entre isolados obtidos da mesma cultura de origem. Tentou-se avaliar a possibilidade de ocorrer diferenças morfológicas entre a região Limeira, tradicionalmente produtora de mudas (Limeira, Araras e Conchal), e os outros municípios amostrados do Estado de São Paulo, entretanto não houve diferenças significativas, invalidando o possível agrupamento das diferenças morfológicas com a região de origem dos isolados fúngicos. Essa estimativa nos induz a supor que para amostragens de levantamentos pormenorizados para o estudo de Phytophthora parasitica no Estado de São Paulo, haverá uma necessidade de um maior número de amostras dessa região.

Durante o experimento para medição de esporângios, o isolado IAC 12/95 produziu poucos esporângios e o isolado IAC 13/95 nenhum. Sendo que o último produziu esporângios em outras condições e por isso eles foram levados em consideração 
na sua identificação, mas não nas comparações das dimensões das estruturas, devido estarem sob diferentes condições culturais.

Tabela 6 . Forma dos esporângios nos diferentes isolados de $P$. parasitica em meio CA.

\begin{tabular}{|c|c|c|c|c|c|c|c|}
\hline \multirow[t]{2}{*}{ Isolado } & \multicolumn{7}{|c|}{ Tipo de forma do esporângio } \\
\hline & Esférico & Elipsóide & Ovóide & Obpiriforme & Obturbinado & Obovóide & disforme \\
\hline IAC $01 / 95$ & + & - & +1 & +1 & - & - & - \\
\hline IAC 02 / 95 & + & - & + & ++ & - & - & - \\
\hline IAC 03 / 95 & + & - & +1 & + & - & - & - \\
\hline IAC 04 / 95 & - & - & + & + & - & - & - \\
\hline IAC $06 / 95$ & - & - & + & + & - & - & - \\
\hline IAC 07 / 95 & - & - & ++ & + & - & - & - \\
\hline IAC 08 / 95 & - & - & + & + & - & - & - \\
\hline IAC 09 / 95 & - & - & ++ & ++ & - & - & - \\
\hline IAC 10 / 95 & - & - & $+t$ & $+t$ & - & - & - \\
\hline IAC $11 / 95$ & + & - & + & + & - & - & - \\
\hline IAC 12 / 95 & - & - & + & + & - & - & - \\
\hline IAC 13 / 95 & - & - & ++ & $+t$ & - & - & +1 \\
\hline IAC 14/ 95 & + & - & ++ & +1 & - & - & + \\
\hline IAC 15 / 95 & - & - & ++ & + & - & - & + \\
\hline IAC $16 / 95$ & + & + & + & - & - & - & - \\
\hline IAC $17 / 95$ & ++ & - & + & + & - & - & - \\
\hline
\end{tabular}



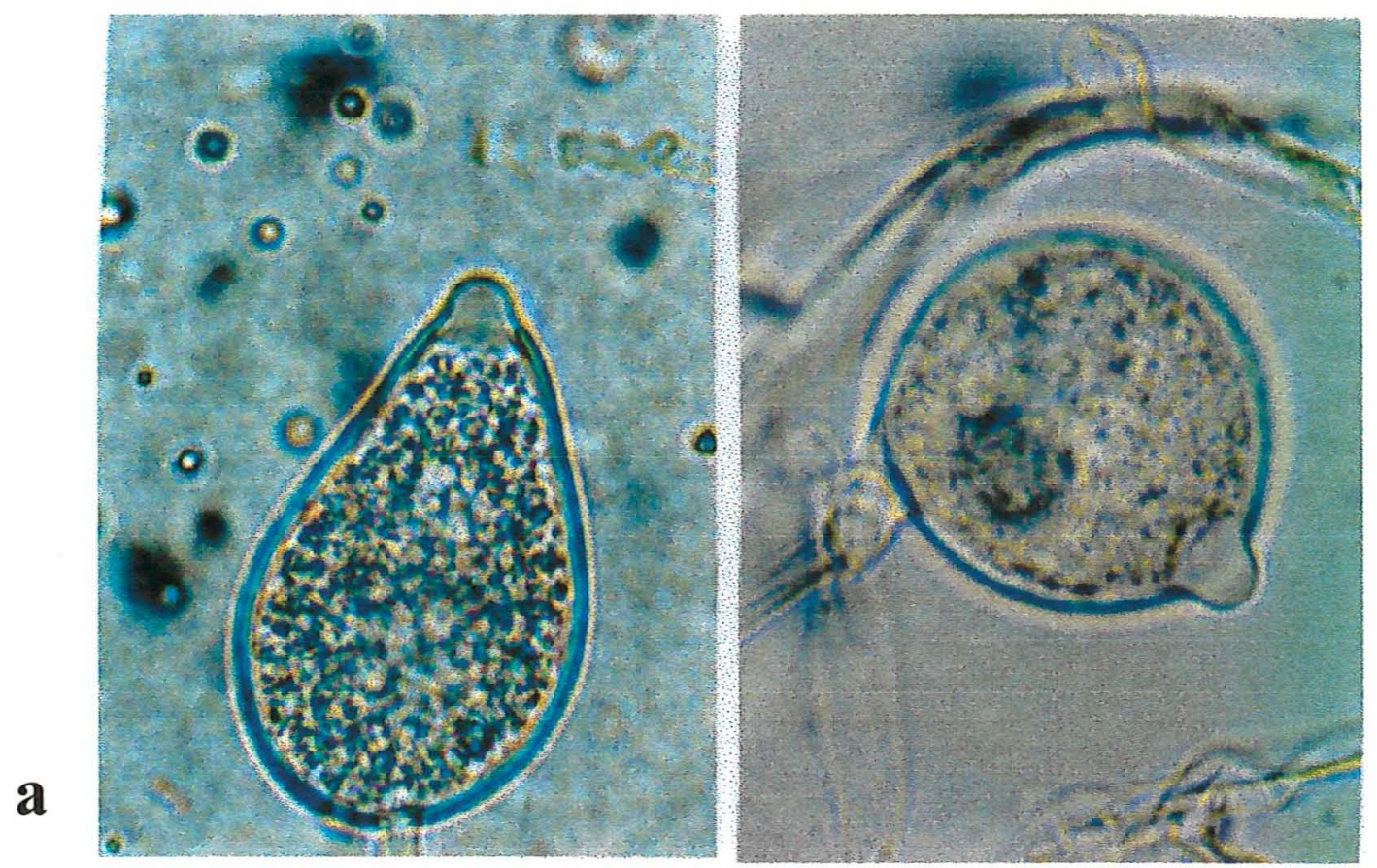

b

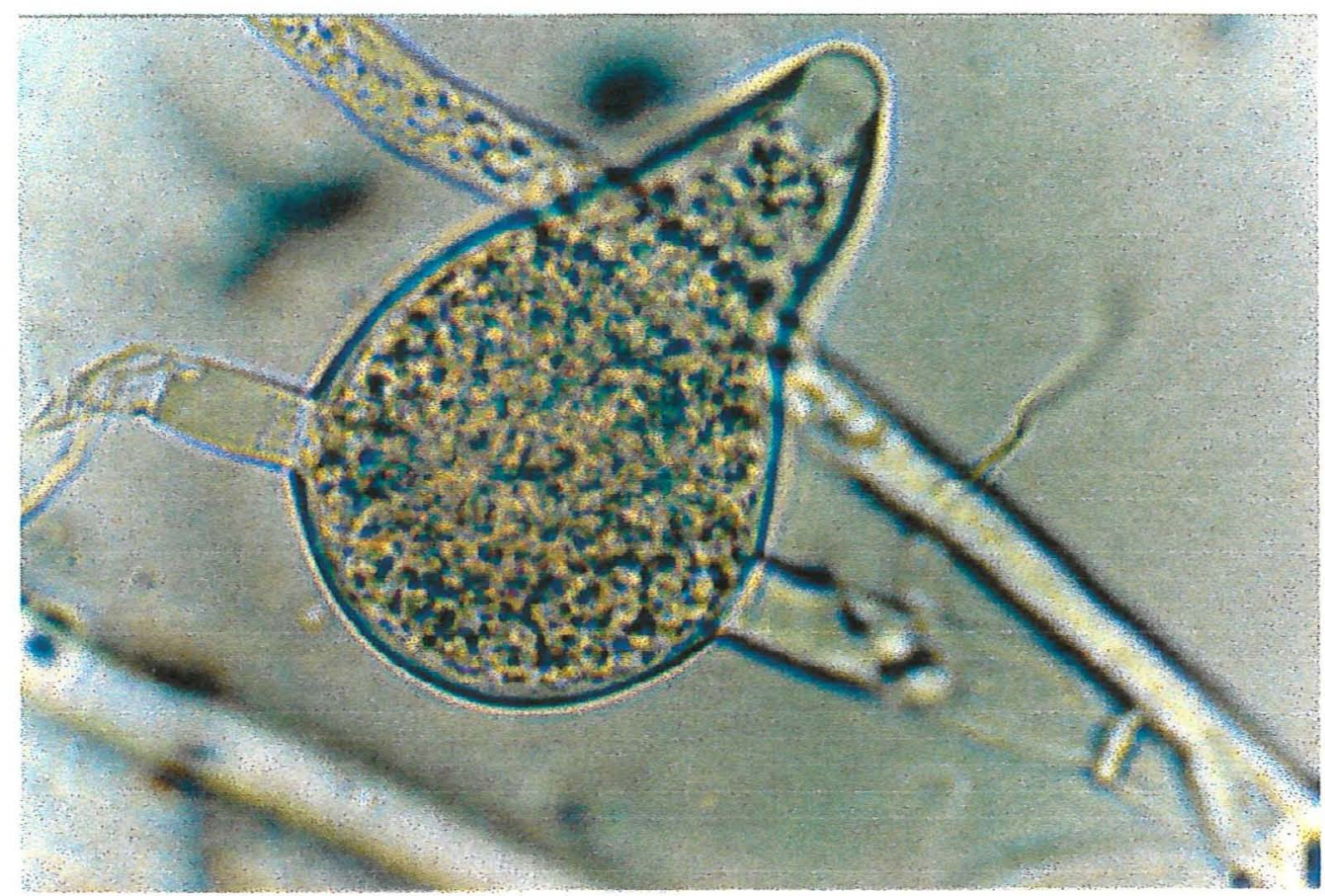

c

Figura 3 - Variação morfológica dos esporângios: :(a) obpiriforme ( 45 x 26 ㅆm); (b) esférico (27 x $23 \mu \mathrm{m})$; e (c) ovóide com inserção intercalar (58 x $36 \mu \mathrm{m})$. 
Tabela 7 . Médias das mensurações dos esporângios dos isolados de $P$. parasitica em meio CA, após 15 dias de crescimento.

\begin{tabular}{|c|c|c|c|}
\hline Isolado & $\begin{array}{c}\text { Comprimento } \\
(\mu \mathrm{m})\end{array}$ & $\begin{array}{c}\text { Largura } \\
(\mu \mathrm{m})\end{array}$ & comp. / largura \\
\hline IAC $01 / 95$ & $35.6 \mathrm{~cd}$ & bcdef & 1.42 \\
\hline IAC 02 / 95 & 37.0 bcd & 23.5 & $1.59 \mathrm{ab}$ \\
\hline IAC 03 / 95 & $45.2 \mathrm{abc}$ & $31.3 \mathrm{abc}$ & 1.46 \\
\hline IAC 04 / 95 & $45.8 \mathrm{abc}$ & $31.5 \mathrm{ab}$ & 1.46 \\
\hline IAC 06 / 95 & $41.0 \mathrm{abc}$ & 27.8 abcde & 1.48 \\
\hline IAC 07 / 95 & $41.4 \mathrm{abc}$ & 28.2 abcde & 1.48 \\
\hline IAC 08 / 95 & 37.8 bcd & 24.3 & $1.55 \mathrm{ab}$ \\
\hline IAC 09 / 95 & $45.9 \mathrm{abc}$ & 28.4 abcde & $1.62 \mathrm{ab}$ \\
\hline IAC 10 / 95 & $42.8 \mathrm{abc}$ & 28.8 abcde & 1.47 \\
\hline IAC $11 / 95$ & $39.5 \mathrm{abcd}$ & 28.0 abcde & 1.40 \\
\hline IAC 12 / 95 & $46.0 \mathrm{abc}$ & $30.8 \mathrm{abcd}$ & $1.49 \mathrm{ab}$ \\
\hline IAC $13 / 95$ & ------ & -------- & ------- \\
\hline IAC $14 / 95$ & 28.4 & 19.7 & 1.45 \\
\hline IAC $15 / 95$ & $48.1 \mathrm{ab}$ & 27.2 abcde & $1.77 \quad \mathrm{a}$ \\
\hline IAC $16 / 95$ & $39.6 \mathrm{abcd}$ & 24.8 & $1.61 \mathrm{ab}$ \\
\hline IAC 17 / 95 & 50.5 a & 32.7 a & $1.54 \mathrm{ab}$ \\
\hline Média & $41.5 \mu \mathrm{m}$ & $27.3 \mu \mathrm{m}$ & 1.52 \\
\hline C.V. $(\%)$ & 17.8 & 15.1 & 11.8 \\
\hline$h^{2}$ & $32.7 \%$ & $38.1 \%$ & $16,3 \%$ \\
\hline
\end{tabular}

Tratamentos com médias seguidas pela mesma letra não diferem estatisticamente pelo teste de Tukey $(5 \%)$ 
A cultura que produziu os maiores esporângios foi o IAC 17/95, enquanto os menores foi o IAC 14/95 (tanto comprimento como largura), os quais são originários da região de Limeira. Isso explica porque não houve formação de grupos quanto à dimensão dos esporângios, já que a maior variação foi encontrado na região de Limeira. A análise de variância dentro de cada região foi realizada, confirmando que não houve diferenças significativas entre os isolados das outras regiões (IAC 06/95; IAC 10/95 e IAC 11/95), enquanto houve diferenças significativas entre os isolados da região de Limeira mesmo a $1 \%$ de probabilidade.

As diferenças significativas nas dimensões dos esporângios entre os diversos isolados monozoospóricos, mesmo da mesma região e da mesma cultura de origem, são evidências da existência de variações intrapopulacionais e da possível ocorrência de heterocariose, respectivamente.

Clamidósporos no meio CA somente foram detectados em alguns isolados (Figura 4), sendo os seguintes IAC 01/95; IAC 03/95; IAC 08/95; IAC 11/95; IAC 12/95; IAC 13/95 e IAC 15/95 (32; 34; 31; 41; 38; 36 e $35 \mu \mathrm{m}$ em média, respectivamente) . Havendo poucos clamidósporos nas placas nos diferentes isolados para mensuração, obteve-se um grande coeficiente de variação, não sendo possível detectar diferenças significativas no diâmetro dos clamidósporos entre os isolados. Em média o diâmetro dos clamidósporos foi de $35 \mu \mathrm{m}$, mas houve uma grande variação dentro dos isolados, sendo as amplitudes máximas de 22.0 e $48.4 \mu \mathrm{m}$.

Ao decompor a variância do diâmetro dos clamidósporos obteve-se $u m h^{2}$ corresponde a 0.041 ou $4.1 \%$, o qual demostra que essa característica é muito variável nas condições de cultivo em meio de cultura, não sendo uma características ideal para detectar diferenças entre isolados, já que isso implica que o ambiente é responsável por mais de $95 \%$ da variação nas condições avaliadas.

Houve a deteç̧ão da presença de um oogônio apenas no isolado IAC 15/95, o qual seria uma possível evidência do comportamento heterotálico dos isolados. Assim o isolado IAC $15 / 95$ seria pertencente a $P$. parasitica, já que para $P$. citrophthora não foi relatado até o momento a produção de estruturas sexuais em meio de cultura, embora em 
tecidos hospedeiros as mesmas tenham sido encontradas. Essa última espécie é considerada para fins de identificação muitas vezes como sem capacidade de produzir estruturas sexuais (Stamps et al., 1990).

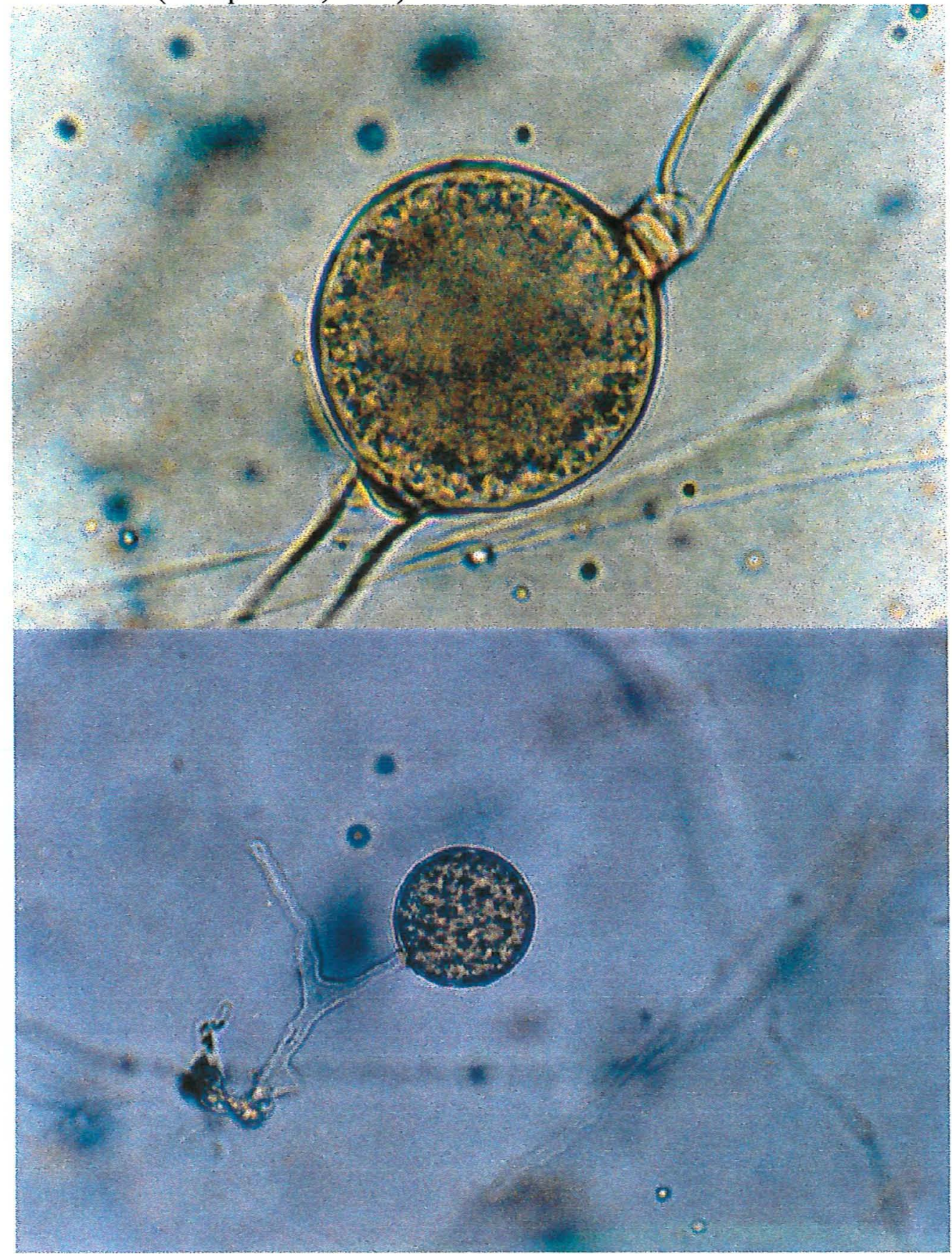

a

b

Figura 4 - Clamidósporo a) intercalar (38 $\mu \mathrm{m}$ de diâmetro) e b) terminal (26 $\mu \mathrm{m}$ de diâmetro). 


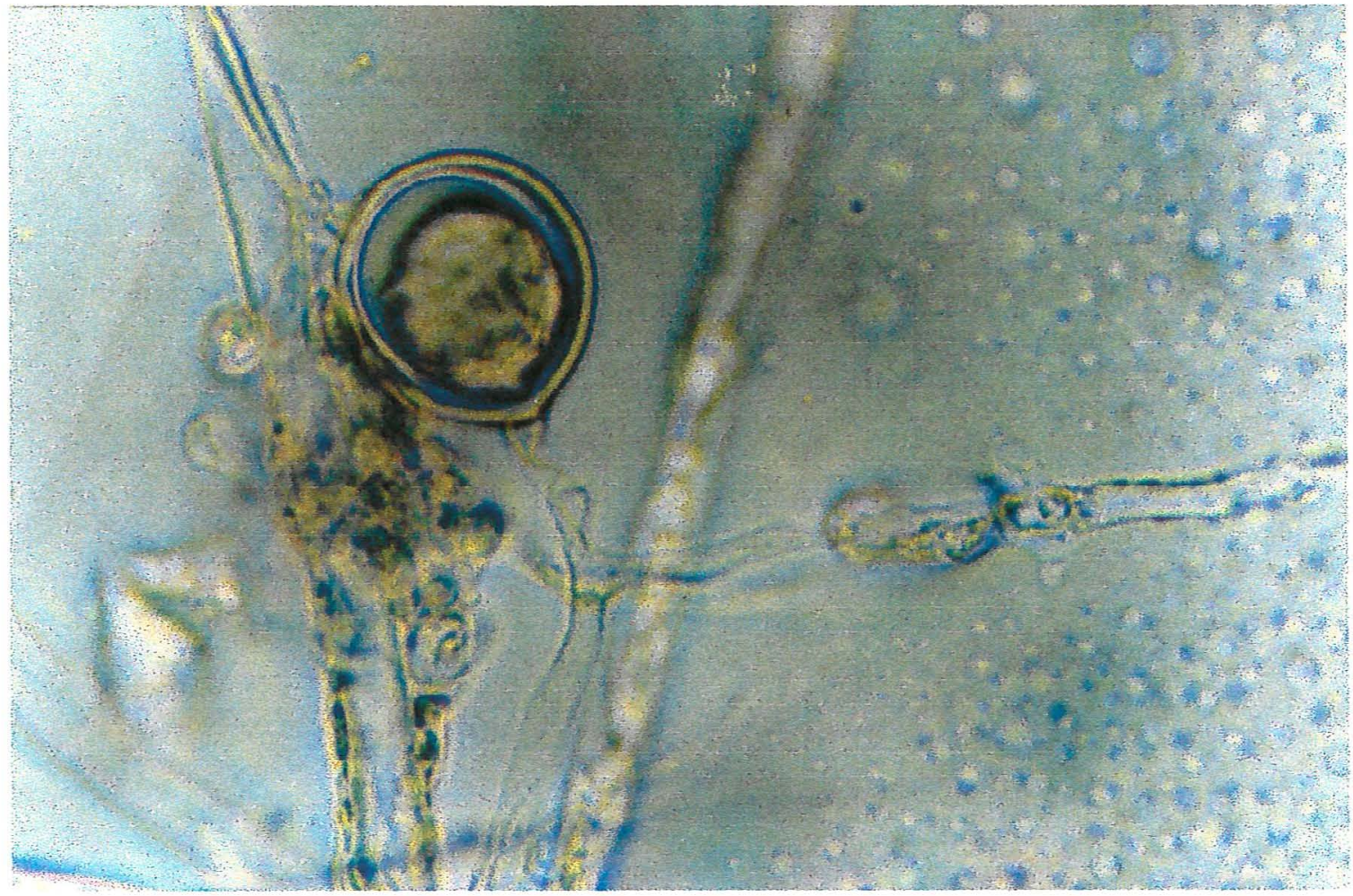

Figura 5 - Presença de oogônio no isolado IAC 15/95 (16.5 x $15 \mu \mathrm{m})$. 


\subsection{Caracterização cultural dos isolados}

Os isolados variaram em seu aspecto de crescimento em meio cenoura-ágar, os tipos de padrões culturais convencionados foram o cotonoso ou sem padrão, o tipo crisântemo, o estrelado, rosáceo e rosáceo-petalóide, como é apresentado na Tabela 8 para cada isolado e o tipo do aspecto do crescimento cultural na Figura 6.

Apesar de Whitehouse (1970) e Stamps et. al.(1990) terem sugerido a utilização do aspecto de crescimento na identificação de espécies, isso não vem sendo feito, porque mesmo culturas monozoospóricas, podem variar de uma placa a outra, como foi observado nos isolados IAC 01/95 e IAC 11/95, não sendo uma característica muito confiável. Entretanto pode servir como referência para algumas espécies com padrões de crescimento bem característicos para ela sob condições bem definidas e meios específicos para o tal. Assim sendo, a informação do tipo de aspecto cultural passa a ser secundária na identificação e caracterização de isolados de espécies, devendo somente ser adotada a variação desses tipos em cada espécie, para os meios empregados rotineiramente no estudo desse gênero.

Tabela 8 . Aspecto cultural das colônias dos isolados de $P$. parasitica em meio CA.

\begin{tabular}{|c|c|}
\hline Isolado & Aspectos \\
\hline IAC $01 / 95$ & crisântemo / estrelado \\
\hline IAC $02 / 95$ & crisântemo \\
\hline IAC $03 / 95$ & crisântemo \\
\hline IAC $04 / 95$ & crisântemo \\
\hline IAC $06 / 95$ & cotonoso \\
\hline IAC $07 / 95$ & crisântemo \\
\hline IAC $08 / 95$ & crisântemo \\
\hline IAC $09 / 95$ & crisântemo \\
\hline IAC 10 / 95 & cotonoso \\
\hline IAC $11 / 95$ & crisântemo / estrelado \\
\hline IAC $12 / 95$ & rosáceo petalóide \\
\hline IAC 13 / 95 & estrelado \\
\hline IAC 14 / 95 & rosáceo \\
\hline IAC 15 / 95 & estrelado \\
\hline IAC 16 / 95 & crisântemo \\
\hline IAC $17 / 95$ & estrelado \\
\hline
\end{tabular}




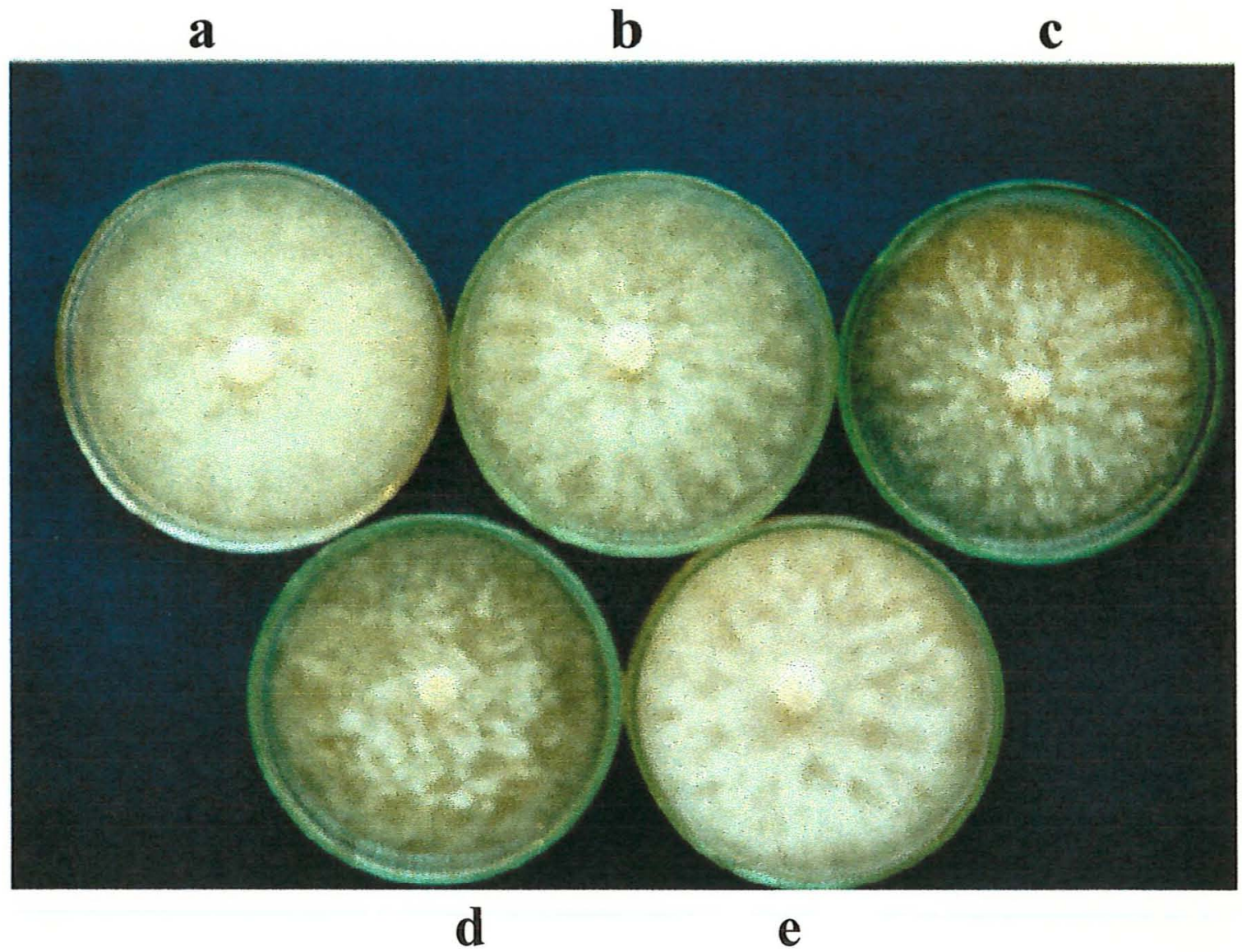

Figura 6 - Variação do aspecto cultural das colônias de $P$. parasitica em meio cenouraágar (CA), a) cotonoso; b) crisântemo; c) estrelado; d) rosáceo e e) rosáceopetalóide. 


\subsection{Crescimento em meio de cenoura ágar a $37^{\circ} \mathrm{C}$}

A determinação do crescimento dos isolados de Phytophthora acima de $35^{\circ} \mathrm{C}$ é uma característica fisiológica de importância na identificação de espécies, já que apenas quatro delas são descritas por Ho (1981) com capacidade para crescerem nessas condições, das quais $P$. parasitica e $P$. dreschleri estão associadas a citros. Os dados morfológicos sugeriam que os isolados estudados neste trabalho tratavam-se de $P$. parasitica, entretanto se algum deles não conseguisse crescer na temperatura cardinal, poderia ter ocorrido um engano ou erro de amostragem, por ficar a dúvida se seria um variante fisiológico ou pela medição aleatória de apenas alguns esporângios pequenos de uma estirpe de $P$. citrophthora. Como todos os isolados estudados cresceram a $37^{\circ} \mathrm{C}$, há condições de assegurar que todos as estirpes pertencem a $P$. parasitica.

$\mathrm{O}$ crescimento a $37^{\circ} \mathrm{C}$ pode ser visualizado na Figura 7 e as taxas de crescimento micelial em diâmetro das colônias em meio sólido estão na Tabela 9. Não houve diferenças estatísticas das taxas de crescimento entre os diferentes isolados. Isto demonstra que o uso da temperatura máxima (cardinal) é importante para diferenciação de espécies, mas não para diferenciação entre isolados, a não ser que se utilize um número maior de repetições. Isto é devido à variação dentro de isolados que aumenta muito, assim como a precisão do experimento que é menor, como pode ser visto pelo alto coeficiente de variação encontrado nesse experimento $(82,1 \%)$. 
Tabela 9 - Coeficientes da regressão linear obtidas para o crescimento dos isolados de $P$. parasitica a $37^{\circ} \mathrm{C}$ em meio CA.

\begin{tabular}{cc}
\hline Isolado & $\mathrm{b}$ (cm/dia) \\
\hline IAC 01 / 95 & 0.22 \\
IAC 02 / 95 & 0.21 \\
IAC 03 / 95 & 0.17 \\
IAC 04 / 95 & 0.58 \\
IAC 06 / 95 & 0.30 \\
IAC 07 / 95 & 0.52 \\
IAC 08 / 95 & 0.58 \\
IAC 09 / 95 & 0.75 \\
IAC 10/95 & 0.49 \\
IAC 11 / 95 & 0.70 \\
IAC 12 / 95 & 0.54 \\
IAC 13 / 95 & 0.63 \\
IAC 14 / 95 & 0.13 \\
IAC 15 / 95 & 0.66 \\
IAC 16 / 95 & 0.38 \\
IAC 17 / 95 & 0.61 \\
\hline Teste F & N.S. \\
Média & 0.468 \\
C.V.(\%) & $82.1 \%$ \\
\hline
\end{tabular}

N.S. = Não houve diferenças estatisticamente significativas. 


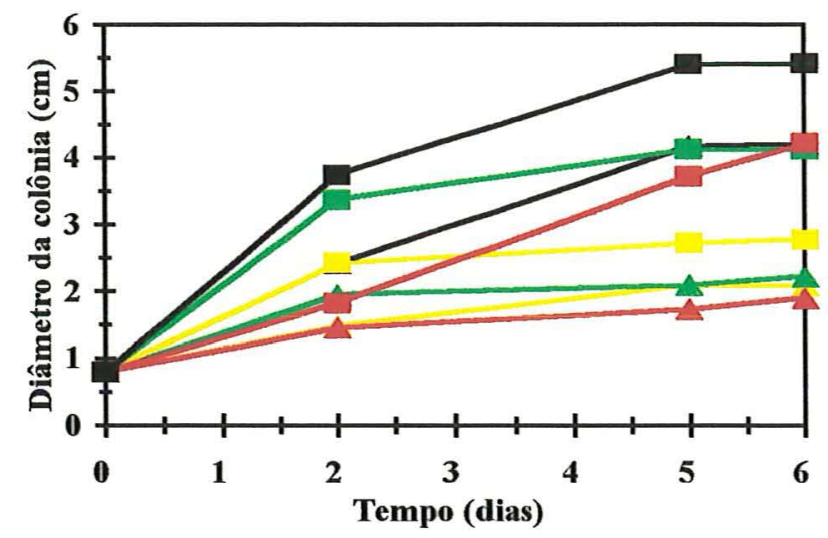

$\operatorname{iac} 01 / 95 \approx \operatorname{iac} 02 / 95 \approx \operatorname{iac} 03 / 95 \approx \operatorname{iac} 04 / 95$ iac 06/95 를 iac 07/95 늘 iac 08/95 늘 iac 09/95

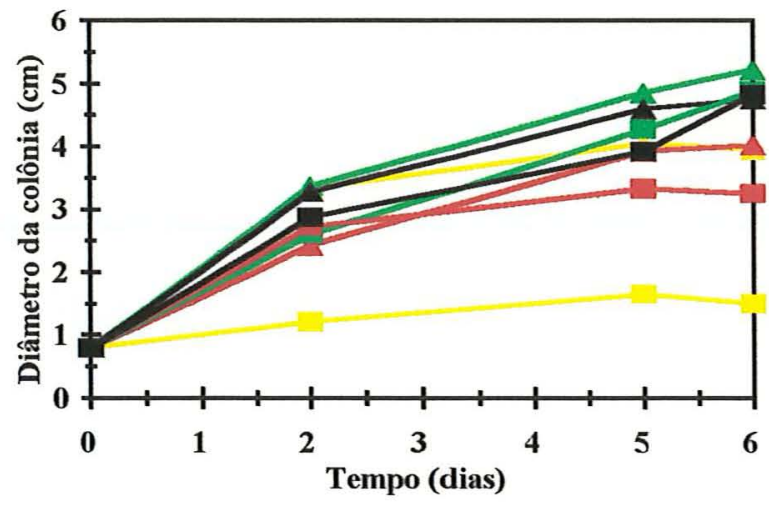

$\operatorname{iac} 10 / 95 \approx \operatorname{iac} 11 / 95 \approx \operatorname{iac} 12 / 95 \approx \operatorname{iac} 13 / 95$

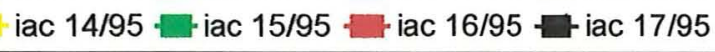

Figura 7 - Curvas de crescimento do diâmetro das colônias dos isolados de $P$. parasitica a $37^{\circ} \mathrm{C}$ em meio cenoura-ágar. 


\subsection{Efeito do metalaxyl nos diferentes isolados}

Todos os isolados de $P$. parasitica foram sensíveis ao fungicida metalaxyl, quanto ao crescimento micelial radial, assim como Guignardia citricarpa (IAC 13/96), diminuindo as diferenças de crescimento entre os isolados nas maiores dosagens. Nas Tabelas 10 e 11 e a Figura 8, podem ser visualizadas as respostas.

O fungicida metalaxyl é um produto sistêmico específico para o controle de oomicetos. Entretanto surgem frequentemente estirpes resistentes a ele, pela pressão seletiva sobre a população sensível. $\mathrm{O}$ resultado do crescimento dos isolados monozoospóricos sem o fungicida (controle), a 1 ppm, 10 ppm e 100 ppm do princípio ativo, podem ser avaliados pelas equações lineares do crescimento em diâmetro das colônias na Tabela 10 e observadas pela Figura 8. A percentagem de inibição nas taxas de crescimento é apresentada na Tabela 11.

Apesar das diferenças de crescimento a $25^{\circ} \mathrm{C}$ não houve correlação entre o crescimento e a sensibilidade ao fungicida, já que o IAC 10/95 e IAC 13/95 tem taxas de crescimento semelhantes (1.86 e $1.74 \mathrm{~cm} / \mathrm{dia}$, respectivamente) enquanto que nas dosagens de 1 e 10 ppm, o primeiro manteve-se com as maiores taxas e o outro as menores.

Os resultados obtidos apresentam populações com tolerância bem maior que os obtidos por May (1994), a qual obteve sempre inibição superior a $80 \%$ a 1 pmm, enquanto a média de todos os isolados foi de 72\%, tendo o IAC 10/95 e o IAC12/95 apresentado 42 e $46 \%$ de inibição, respectivamente. A 10 ppm houve crescimento, entretanto deve ser ressaltado que ocorre um maior tempo lag, para iniciar o crescimento micelial, podendo ser pela degradação parcial do produto com os dias, ou pela lenta adaptação do patógeno para sintetizar as suas enzimas, que degradem ou sejam menos sensíveis a ele. Estes fatos aumentam a importância de um monitoramento mais amplo e constante sobre a resistência a esse fungicida.

O metalaxyl apesar de ser considerado específico para oomicetos afetou o crescimento do isolado IAC 13/96 (Guignardia citricarpa), um ascomiceto, considerado 
não afetado pelos fungicidas do grupo das acilamidas, ao ponto de reduzir em $74 \%$ o seu crescimento radial em 100 ppm do princípio ativo.

Os dados apresentados nas tabelas mostram que há uma certa tolerância natural ao metalaxyl (1 ppm e 10 ppm), embora sua liberação oficial para uso na citricultura, somente tenha ocorrido no ano de 1994, quando todas as estirpes usadas para este trabalho, já haviam sido isoladas e conservadas no Laboratório Regional de Sorocaba, IB.

O efeito ao nível microscópico pode ser visualizado pela Figura 9, onde houve uma modificação no aspecto e número das hifas nas diferentes concentrações do fungicida no meio de cultura. No controle houve grande número de hifas e normalmente bem cilíndricas, enquanto que ao aumentar a quantidade do fungicida do meio houve uma redução do número de hifas, como também um engrossamento das hifas e um aumento da afinidade das hifas com o corante azul de tripan. 
Tabela 10 . Estimativa da taxa de crescimento em diâmetro das colônias dos isolados de P. parasitica a $25^{\circ} \mathrm{C}$ em meio $\mathrm{CA}$ em diferentes concentrações de metalaxyl.

Taxa de crescimento $(\mathrm{cm} / \mathrm{dia})$

\begin{tabular}{|c|c|c|c|c|}
\hline Isolado & $0 \mathrm{ppm}$ & $1 \mathrm{ppm}$ & $10 \mathrm{ppm}$ & $100 \mathrm{ppm}$ \\
\hline IAC $01 / 95$ & $1.29 \mathrm{bc}$ & 0.11 & $0.01 \mathrm{de}$ & 0.01 \\
\hline IAC 02 / 95 & $1.50 \mathrm{abc}$ & 0.80 & $0.10 \mathrm{bcd}$ & 0.01 \\
\hline IAC $03 / 95$ & $1.37 \mathrm{abc}$ & 0.26 cde & 0.09 bcde & 0.03 \\
\hline IAC 04 / 95 & $1.35 \mathrm{abc}$ & 0.33 cde & 0.09 bcde & 0.00 \\
\hline IAC $06 / 95$ & $1.65 \mathrm{abc}$ & 0.18 cde & $0.05 \mathrm{de}$ & 0.00 \\
\hline IAC 07 / 95 & $1.47 \mathrm{abc}$ & 0.43 abcde & $0.00 \quad \mathrm{e}$ & 0.01 \\
\hline IAC 08 / 95 & $1.20 \mathrm{c}$ & 0.40 bcde & $0.14 \mathrm{abc}$ & 0.04 \\
\hline IAC $09 / 95$ & $1.42 \mathrm{abc}$ & $0.55 \quad a b c$ & $0.16 \quad \mathrm{ab}$ & 0.01 \\
\hline IAC $10 / 95$ & $1.86 \mathrm{a}$ & 0.84 & $0.20 \quad \mathrm{a}$ & 0.02 \\
\hline IAC $11 / 95$ & $1.47 \mathrm{abc}$ & 0.54 abcd & 0.07 cde & 0.00 \\
\hline IAC $12 / 95$ & $1.86 \mathrm{ab}$ & $0.78 \quad a b$ & $0.03 \mathrm{de}$ & 0.01 \\
\hline IAC $13 / 95$ & $1.74 \mathrm{abc}$ & $0.13 \mathrm{de}$ & $0.05 \mathrm{de}$ & 0.00 \\
\hline IAC $14 / 95$ & $1.30 \mathrm{bc}$ & 0.22 cde & $0.16 \quad a b$ & 0.02 \\
\hline IAC $15 / 95$ & $1.75 \mathrm{abc}$ & 0.21 cde & $0.06 \mathrm{cde}$ & 0.02 \\
\hline IAC $16 / 95$ & $1.47 \mathrm{abc}$ & $0.16 \mathrm{cde}$ & $0.03 \mathrm{de}$ & 0.01 \\
\hline IAC $17 / 95$ & $1.60 \mathrm{abc}$ & 0.26 cde & $0.05 \mathrm{de}$ & 0.02 \\
\hline Teste F & $* *$ & $* *$ & $* *$ & N.S. \\
\hline Média & 1.52 & 0.39 & 0.07 & 0.01 \\
\hline C.V.(\%) & 12.2 & 35.7 & 38.1 & 126.6 \\
\hline
\end{tabular}

Médias seguidas pela mesma letra não diferem estatisticamente pelo teste de Tukey (5\%)

$* *=$ diferenças estatisticamente significativas a $1 \%$ de erro

N.S. = Não houve diferenças estatisticamente significativas. 
Tabela 11 . Percentagem (\%) na inibição da taxa de crescimento em diâmetro das colônias de $P$. parasitica em meio CA, pelo fungicida metalaxyl a $25^{\circ} \mathrm{C}$.

\begin{tabular}{cccc}
\hline Isolado & $1 \mathrm{ppm}$ & $10 \mathrm{ppm}$ & $100 \mathrm{ppm}$ \\
\hline IAC 01 / 95 & 92.16 & 93.41 & 98.35 \\
IAC 02 / 95 & 46.28 & 92.87 & 99.13 \\
IAC 03 / 95 & 79.20 & 93.45 & 98.18 \\
IAC 04 / 95 & 72.95 & 93.51 & 99.82 \\
IAC 06 / 95 & 84.61 & 96.05 & 99.64 \\
IAC 07 / 95 & 71.96 & 98.57 & 99.11 \\
IAC 08 / 95 & 75.39 & 88.06 & 96.38 \\
IAC 09 / 95 & 58.39 & 88.40 & 98.01 \\
IAC 10 / 95 & 42.61 & 86.34 & 98.42 \\
IAC 11 / 95 & 61.67 & 94.02 & \\
IAC 12 / 95 & 46.14 & 96.64 & 98.58 \\
IAC 13 / 95 & 92.76 & 96.29 & 99.65 \\
IAC 14 / 95 & 81.68 & 88.01 & 98.15 \\
IAC 15 / 95 & 83.48 & 95.28 & 98.78 \\
IAC 16 / 95 & 87.86 & 97.68 & 99.46 \\
IAC 17 / 95 & 77.88 & 93.45 & 98.05 \\
IAC 13 / 96 & & & \\
& 18,27 & 19,23 & 74,04 \\
Média & & & \\
\hline
\end{tabular}


Efeito de metalaxyl em Phytophthora IAC 01/95

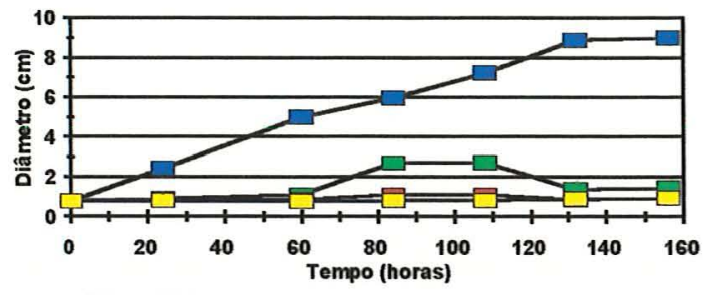

을 0 ppm $\square 1 \mathrm{ppm} \square 10 \mathrm{ppm} \square 100 \mathrm{ppm}$

Efeito de metalaxyl em Phytophthora IAC 03/95

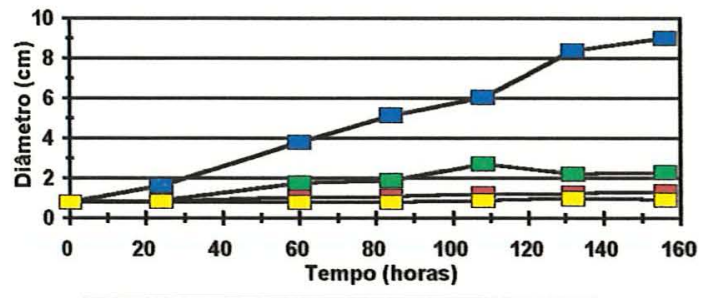

0 ppm $\square 1$ ppm $\square 10$ ppm $\square 100$ ppm
Efeito de metalaxyl em Phytophthora IAC 02/95

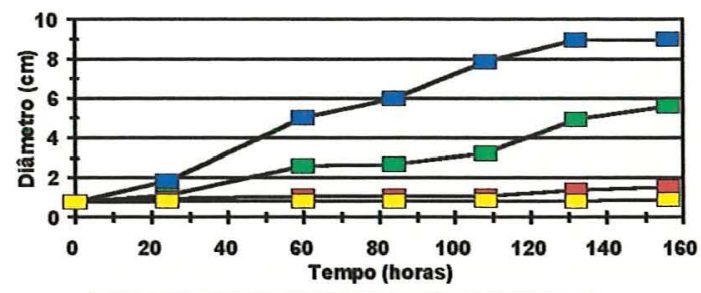

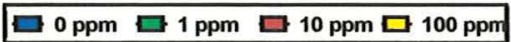

Efeito de metalaxyl em Phytophthora IAC 04/95

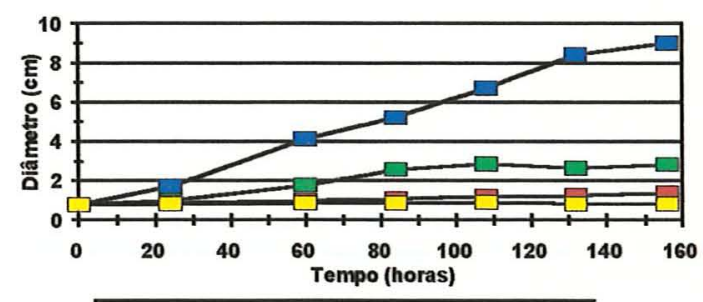

ㅇpㅁㅁ 1 ppm 10 ppm 100 ppm

Figura 8 - Curvas de crescimento em diâmetro das colônias dos isolados IAC 01/95; IAC 02/95; IAC O3/95 e IAC 04/95, em 0; 1; 10 e 100 ppm de metalaxyl em meio cenoura-ágar (CA). 
Efeito de Metalaxyl a Phytophthora IAC $06 / 95$

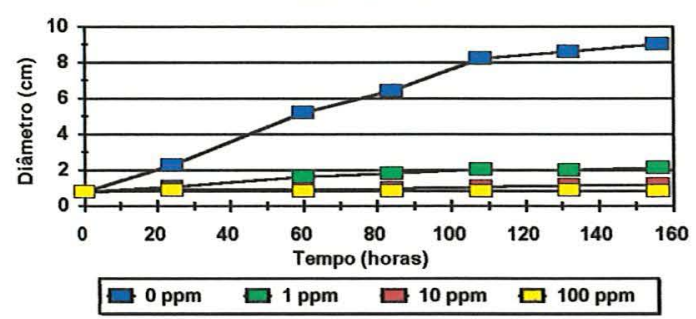

Efeito de Metalaxyl a Phytophthora IAC $08 / 95$

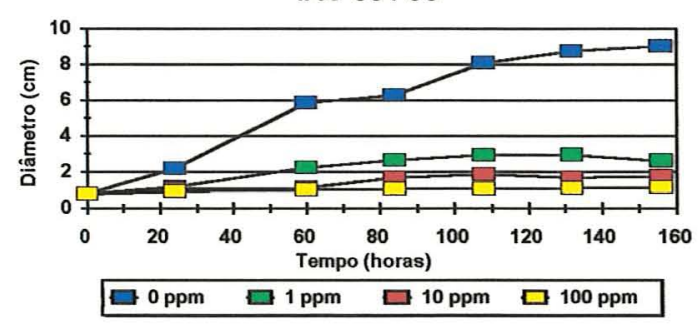

Efeito de Metalaxyl a Phytophthora IAC $07 / 95$

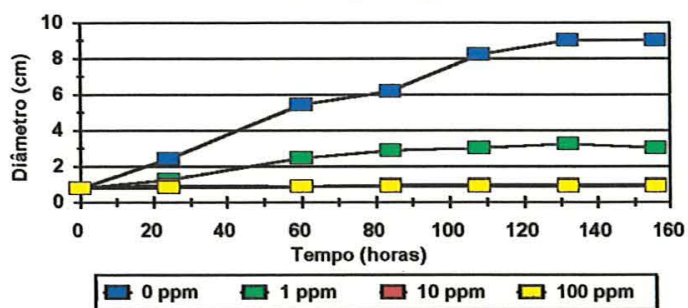

Efeito de Metalaxyl a Phytophthora IAC $09 / 95$

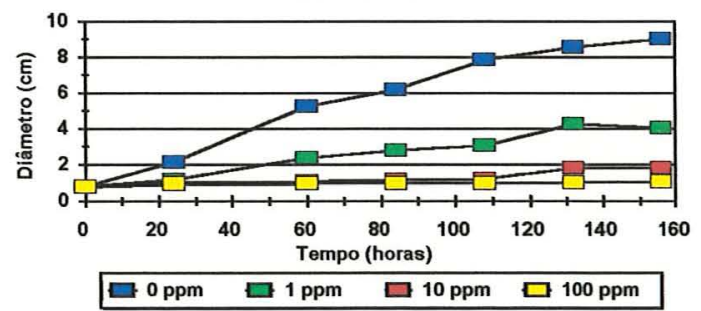

Figura 8 - Curvas de crescimento em diâmetro das colônias dos isolados IAC 06/95; IAC 07/95; IAC O8/95 e IAC 09/95, em 0; 1; 10 e 100 ppm de metalaxyl em meio cenoura-ágar (CA). 
Efeito de metalaxyl em Phytophthora IAC 10/95

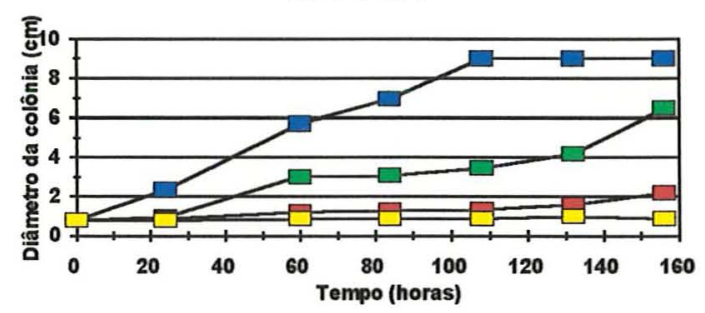

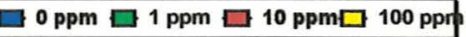

Efeito de metalaxyl em Phytophthora

IAC $11 / 95$

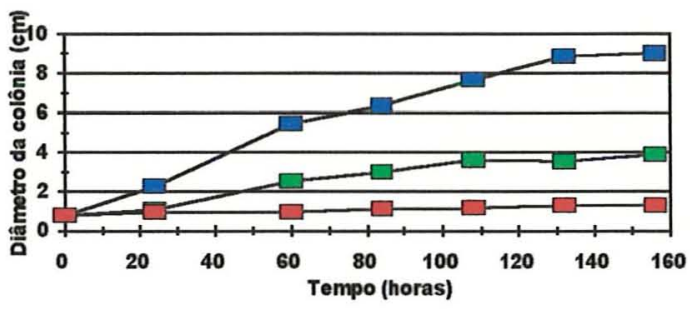

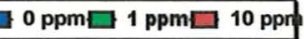

Efeito de metalaxyl em Phytophthora IAC $13 / 95$

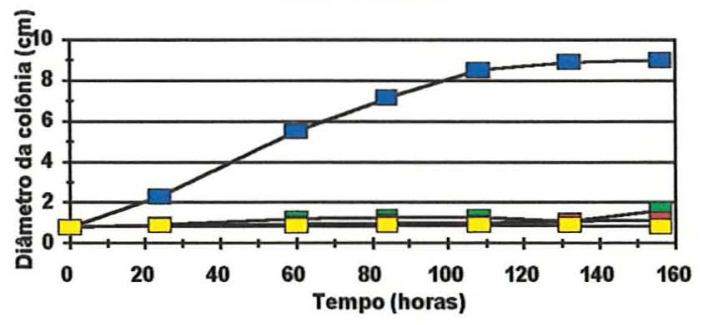

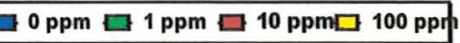

Figura 8 - Curvas de crescimento em diâmetro das colônias dos isolados IAC 10/95; IAC 11/95; IAC 12/95 e IAC 13/95, em 0; 1; 10 e 100 ppm de metalaxyl em meio cenoura ágar (CA). 
Efeito de metalaxyl em Phytophthora IAC 14 / 95

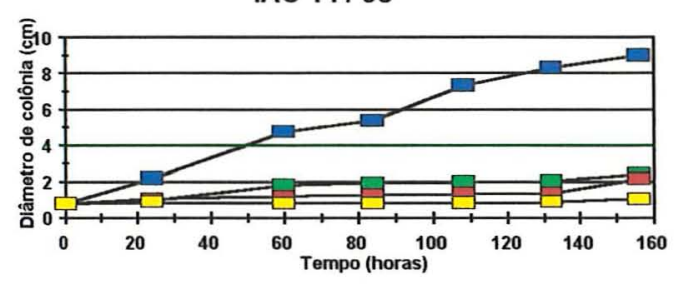

$\square 0$ ppm $\square 1$ ppm $\square 10$ ppm $\square 100$ ppm
Efeito de metalaxyl em Phytophthora IAC 15/95

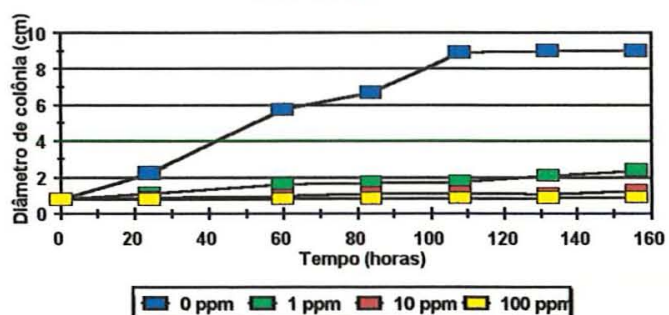

ㅇp물 1 ppm 10 ppm
Efeito de metalaxyl em Phytophthora

\section{IAC $16 / 95$}

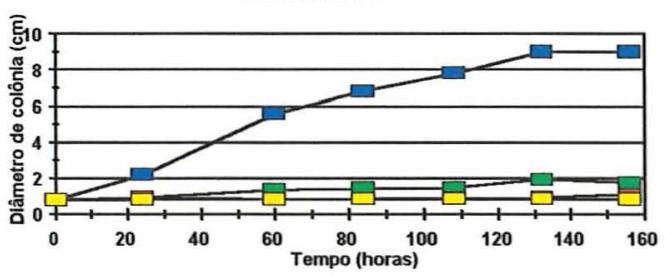

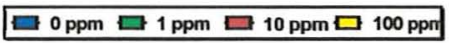

Efeito de metalaxyl em Phytophthora IAC 17 / 95

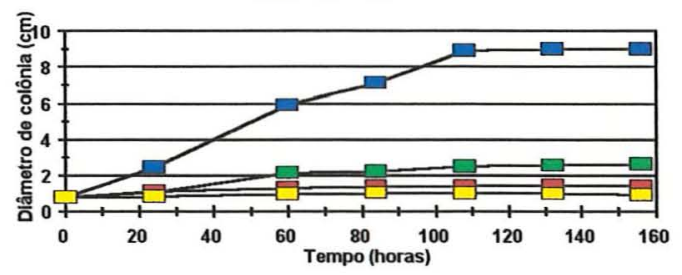

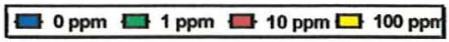

Figura 8 - Curvas de crescimento em diâmetro das colônias dos isolados IAC 14/95; IAC 15/95; IAC 16/95 e IAC 17/95, em 0; 1; 10 e 100 ppm de metalaxyl em meio cenoura-ágar (CA). 

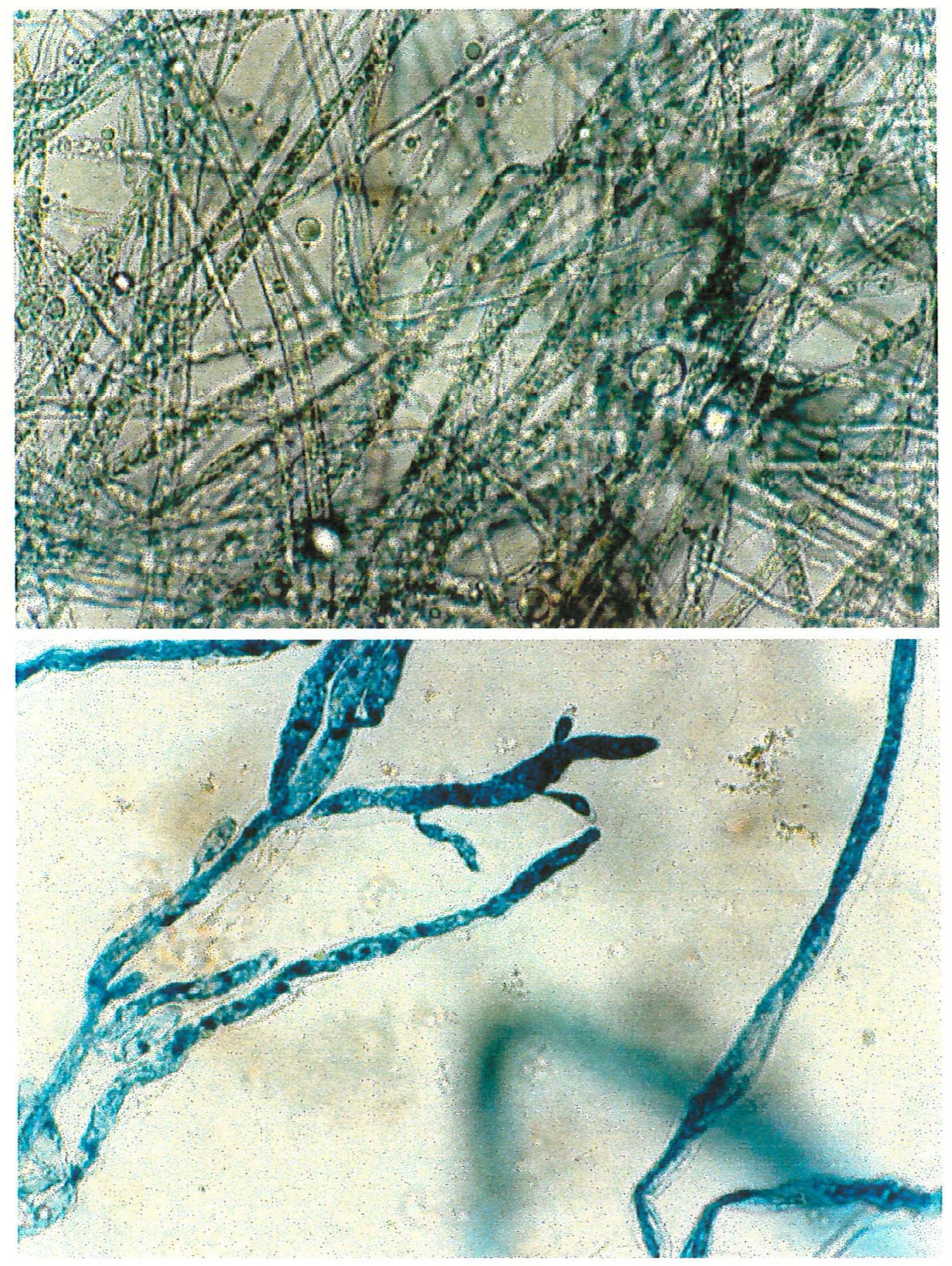

$\mathbf{a}$

Figura 9 - Efeito do metalaxyl no aspecto das hifas de $\boldsymbol{P}$. parasitica a) aspecto normal no meio cenoura-ágar; b) aspecto com 10 ppm de metalaxyl no meio cenoura ágar (CD). 


\subsection{Otimização das condições de produção do micélio fúngico}

Na produção de micélio fúngico para a realização da extração do DNA, há necessidade de obter-lo com rapidez e em quantidade suficiente para no final do processo termos um DNA de qualidade e na quantidade desejada. A tentativa de usar a agitação não foi satisfatória devido ao crescimento lento que sofria paralisação logo após alguns dias, formando estruturas esféricas e compactas de micélio (Figura 11). $\mathrm{O}$ crescimento em meio líquido sem agitação produz maiores quantidades de micélio fúngico, mas é lento e demora mais de 12 a 15 dias para poder ser utilizado.

A modificação pelo emprego de uma suspensão de zoósporos das colônias, sendo inoculadas com apenas $200 \mu \mathrm{l}$ em placas de petri com $20 \mathrm{ml}$ de meio cenoura, foi suficiente para se obter grandes quantidades de micélio novo após 4 dias de incubação. Observou-se também que o micélio tomava a coloração alaranjada quando a cenoura do meio de cultura era preparada por liquidificador, entretanto isso não ocorria quando o meio era produzido por fervura.

A modificação na produção do micélio foi extremamente importante pela diminuição no tempo, necessidade de menor espaço, a quantidade obtida e pelo micélio estar novo, diminuindo as impurezas que levam a um maior número de passos durante a extração do DNA. 


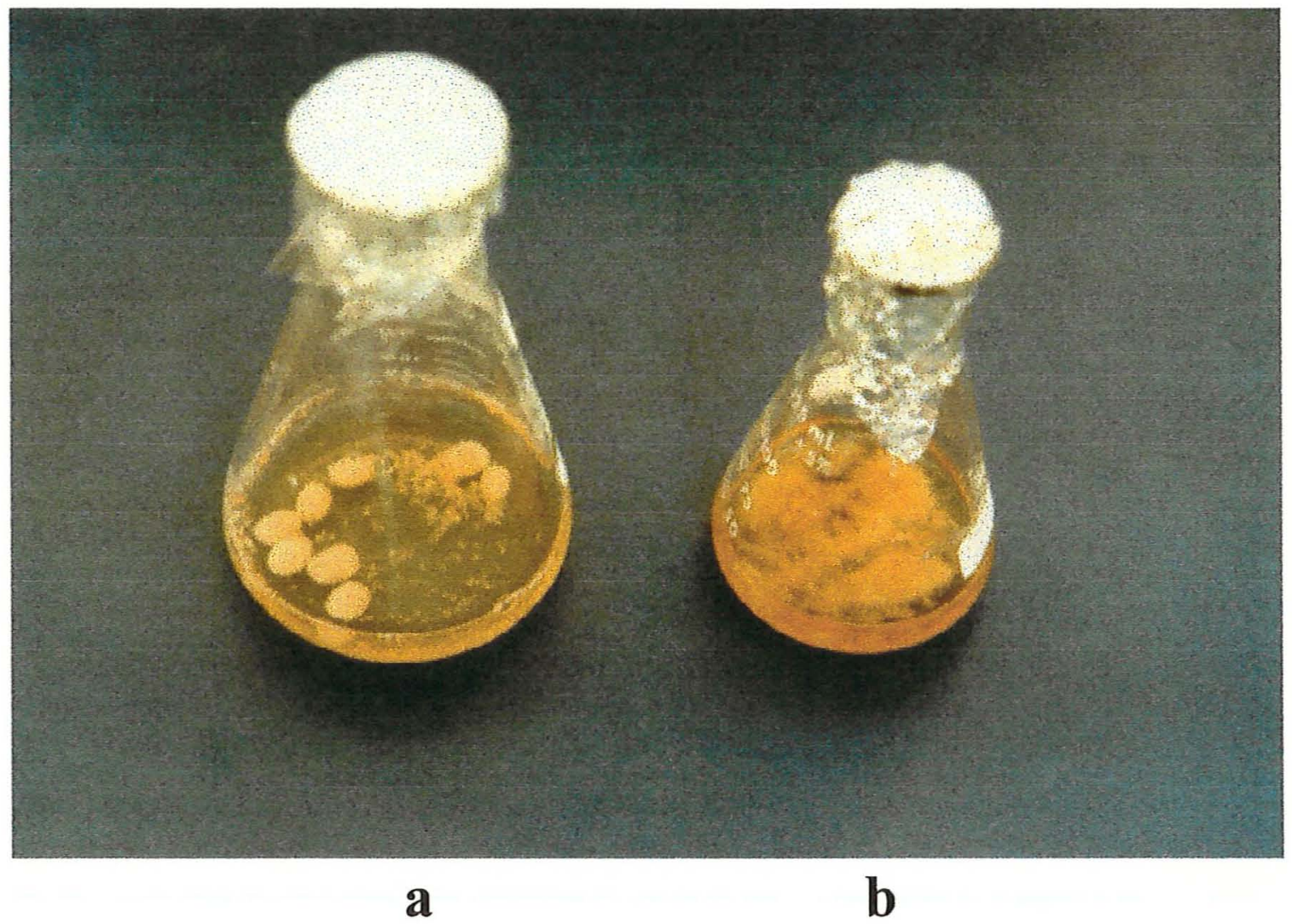

Figura 10 - Aspecto do crescimento micelial, a) com agitação a $100 \mathrm{rpm}$ a $28^{\circ} \mathrm{C} \mathrm{e} \mathrm{b}$ ) sem agitação à temperatura ambiente. 


\subsection{Otimização das condições de RAPD}

Após a otimização da produção do micélio houve a necessidade de otimizar as condições para a realização da amplificação do DNA pela reação de RAPD. Entre as variáveis que foram otimizadas, destacam-se a quantidade do DNA, o número de unidades da enzima para cada reação e a seleção dos oligonucleotídeos que poderiam ser usados para a detecção do polimorfismo entre os isolados estudados.

\subsubsection{Otimização da quantidade de DNA na reação de amplificação}

O primeiro ensaio para otimização da quantidade de DNA foi realizado com 20 , 40, 60 e $100 \mathrm{ng}$ de DNA do isolado IAC 01/95 e as condições assim como os outros componentes da reação foram como especificado no item 3.16., além de serem utilizados os oligonucleotídeos OPE - 02, OPE - 03 e OPE - 07. Houve amplificação pelos três oligonucleotídeos empregados, no OPE - 03 foi em todas as quantidades de DNA testadas, enquanto nos outros a amplificação cessava bruscamente nas maiores quantidades de DNA, 40 ng e 60 ng para o OPE - 02 e OPE - 07, respectivamente. Essa falta de amplificação total quando há um excesso de DNA não é relatado para outros fungos como Guignardia citricarpa (Glienke, 1995), nos quais há uma diminuição gradual das bandas amplificadas à medida que aumenta a quantidade de DNA para a reação de RAPD, entretanto esse comportamento é frequente em DNAs de plantas ou mesmo em bactérias (Araújo, 1996). Ferreira e Grattapaglia (1995) sugerem que esse fato deva ocorrer por um excesso de impurezas agregadas ao DNA que podem reduzir ou até mesmo inibir significativamente a atividade de polimerização da enzima Taq polimerase, resultando, ou na falha completa da reação, ou de perfis eletroforéticos com arraste e bandas pouco definidas.

O segundo ensaio para otimização da quantidade de DNA foi realizado com 10, $20,40,60,80$ e $100 \mathrm{ng}$ de DNA dos isolados IAC 01/95 e IAC 02/95, nas mesmas condições do primeiro ensaio, mas com os oligonucleotídeos OPE - 06, OPE - 15 e OPE 
- 18. Houve novamente amplificação do DNA, tanto do IAC 01 / 95 como do IAC 02 / 95, não diferindo entre eles nos fragmentos amplificados, o que já é uma evidência da alta similaridade entre os isolados de Phytophthora parasitica (Figura 11). Nenhum dos oligonucleotídeos usados amplificou em todas as quantidades de DNA genômico, como ocorreu no primeiro ensaio com o oligonucleotídeos OPE - 03, mas eles somente amplificaram até 20,60 e 40 ng de DNA para os oligonucleotídeos OPE - 06, OPE - 15 e OPE - 18, respectivamente.

Entretanto novamente houve uma amplificação que visualmente aparenta ser dependente da quantidade de DNA inicial e do oligonucleotídeo da reação de amplificação, como pode ser observado na Figura 11, diferindo da hipótese que seria por impurezas do DNA, porque se assim fosse deveria ser independente de qual oligonucleotídeo está sendo usado na amplificação e do DNA molde. Como isso não foi observado, a perda da amplificação não deve ser simplesmente por impurezas que atuam sobre a enzima Taq DNA polimerase.

Com o intuito de evitar a perda da amplificação dos DNAs dos isolados, na posterior avaliação de polimorfismo entre eles, foi escolhido adicionar 20 ng de DNA na reação de amplificação de RAPD. Não sendo escolhido menores quantidades porque baixas concentrações de DNA resultam numa amplificação errática ou não há amplificação de certos fragmentos com perfis de eletroforese não reproduzíveis. Apesar de outros testes realizados demostrarem que mesmo quantidades como 100 pg de DNA genômico de $P$. parasitica podem ser amplificados por alguns oligonucleotídeos, semelhantemente ao limite máximo da quantidade de DNA, o limite mínimo para que ocorra a amplificação também é dependente do oligonucleotídeo e da quantidade do DNA molde inicial. 


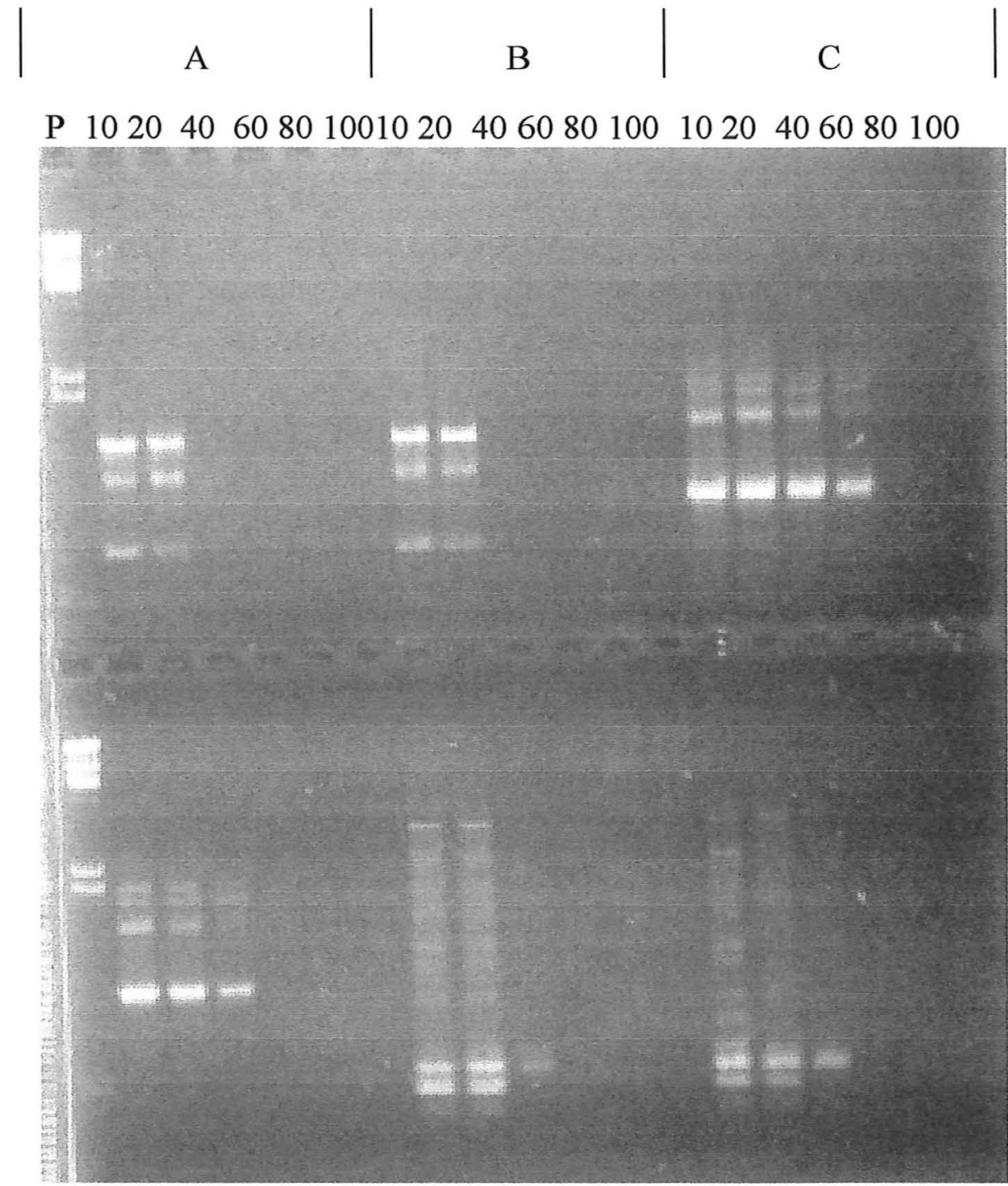

P 102040608010010204060801001020406080100

$\mathrm{D}$

E

$\mathrm{F}$

Figura 11 Otimização da quantidade de DNA na reação de amplificação, com os isolados IAC 01/95 (a, c, e) e IAC 02/95 (b, d, f); com 10; 20; 40; 60; 80 e $100 \mu \mathrm{g}$ de DNA e três oligonucleotídeos iniciadores OPE - 06 (a, b); OPE - 15 (c, d) e OPE - $18(\mathrm{e}, \mathrm{f})$. 
4.7.2. Otimização do número de unidades da enzima Taq DNA polimerase para a reação de amplificaçầo

A otimização do número de unidades da enzima Taq DNA polimerase é realizada principalmente de um ponto de vista econômico, devido que é ela a principal responsável pelo custo unitário de cada reação de amplificação, chegando a $80 \%$ do custo (Ferreira $\&$ Grattapaglia, 1995). O ensaio de otimização realizado com $0.5 ; 1.0 ; 1.5$ e 2.0 unidades da enzima (figura 12), revelou que somente ocorreu amplificação do DNA a partir de 1.5 unidades, entretanto a melhor amplificação ocorreu com 2.0 unidades/reação; essa última quantidade foi responsável pelo aumento da intensidade nas bandas amplificadas.

Em geral as reações empregam 1 unidade da enzima e que em quantidades superiores possa a vir produzir amplificações não específicas e consequentemente perfis de bandas com arraste ou bandas sobrepostas muito intensas (Ferreira \& Grattapaglia, 1995). Entretanto esses mesmos autores citam que para algumas marcas da enzima, há necessidade de maiores concentrações para manter a eficiência da amplificação, evitando a perda na intensidade de alguns fragmentos amplificados. Essa explicação deve ser a mais provável para os resultados, já que não ocorre amplificação nenhuma com 1 unidade da enzima, assim como muitos outros trabalhos vem sendo realizados com a mesma quantidade da enzima escolhida, como ocorre em bactérias endofiticas (Araújo, 1996) e em Guignardia citricarpa (Glienke, 1994). 


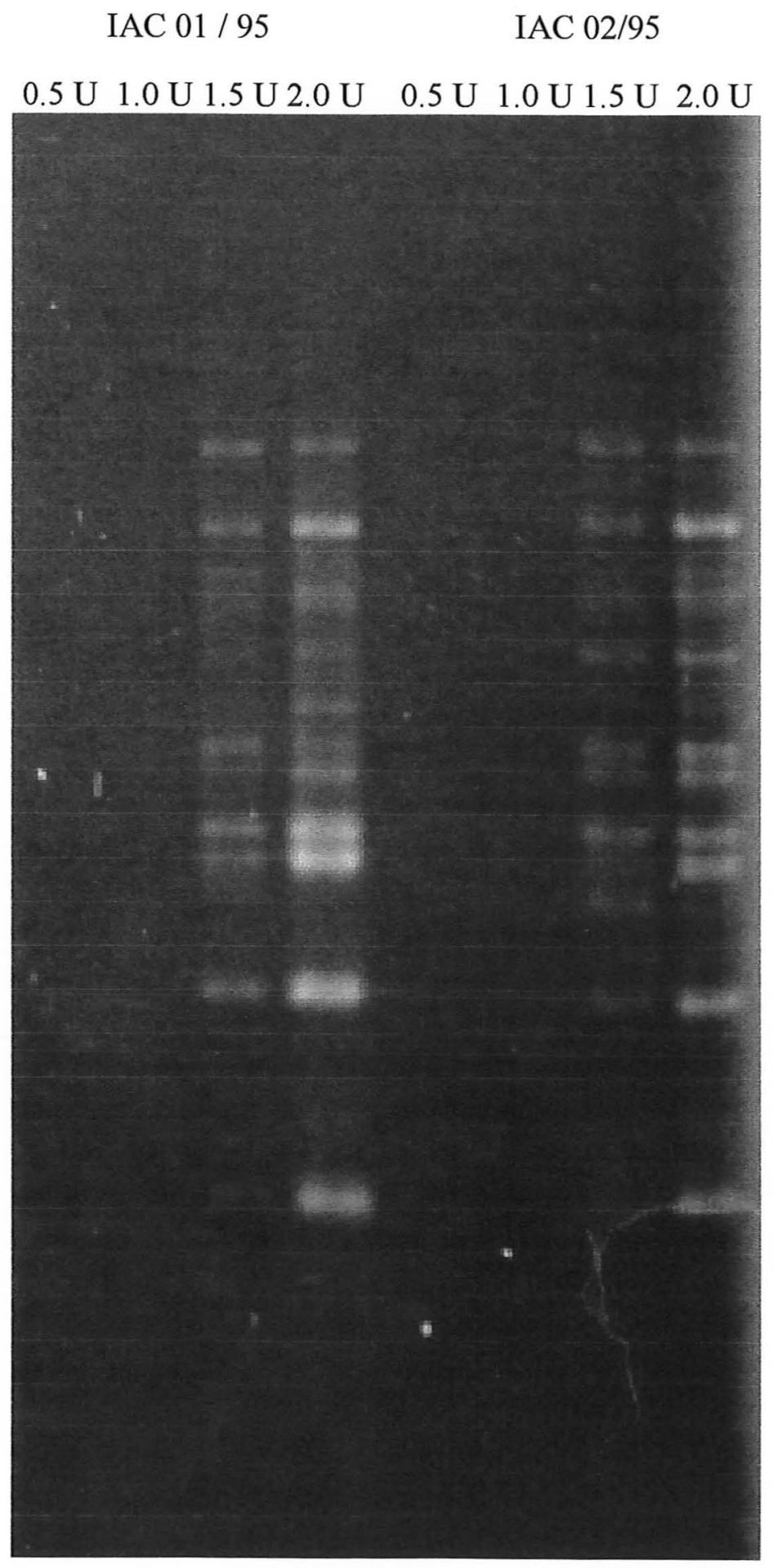

Figura 12 - Otimização do número de unidades da enzima Taq DNA polimerase para a reação de amplificação. 
4.7.3. Seleção de oligonucleotídeos na reação de amplificação

Nesse ensaio todos os oligonucleotídeos iniciadores foram usados numa concentração de $0.4 \mu \mathrm{M}$ no volume final da reação, para ter certeza que não seria limitante para nenhum deles a quantidade dos mesmos para que possa ocorrer a amplificação. Williams et. al. (1990) já relatam que o uso de concentrações menores que $0.2 \mu \mathrm{M}$ pode levar a dificeis visualizações dos fragmentos amplificados, enquanto concentrações maiores não possuem grande influência na intensidade das bandas, pelo qual foi fixado em essa quantidade de trabalho, para ter uma faixa de segurança confiável para esta variável.

A seleção foi realizada com 36 oligonucleotídeos dos quais 26 amplificaram, entretanto somente 21 produziram mais de três fragmentos para o DNA teste (isolado IAC 01/95), como pode ser visualizado na Figura 13. Os oligonucleotídeos selecionados do kit $\mathrm{E}$ da Operon foram oito, os quais foram OPE - 03, OPE - 04, OPE - 06, OPE - 12, OPE - 14, OPE - 15, OPE - 16, OPE - 18 e o OPE - 19; enquanto no kit $\mathrm{X}$ foram onze oligonucleotídeos, os quais são OPX - 01, OPX - 02, OPX - 03, OPX - 07, OPX - 08, OPX - 09, OPX - 11, OPX - 12, OPX - 13, OPX - 14, OPX - 15 e OPX - 17. 

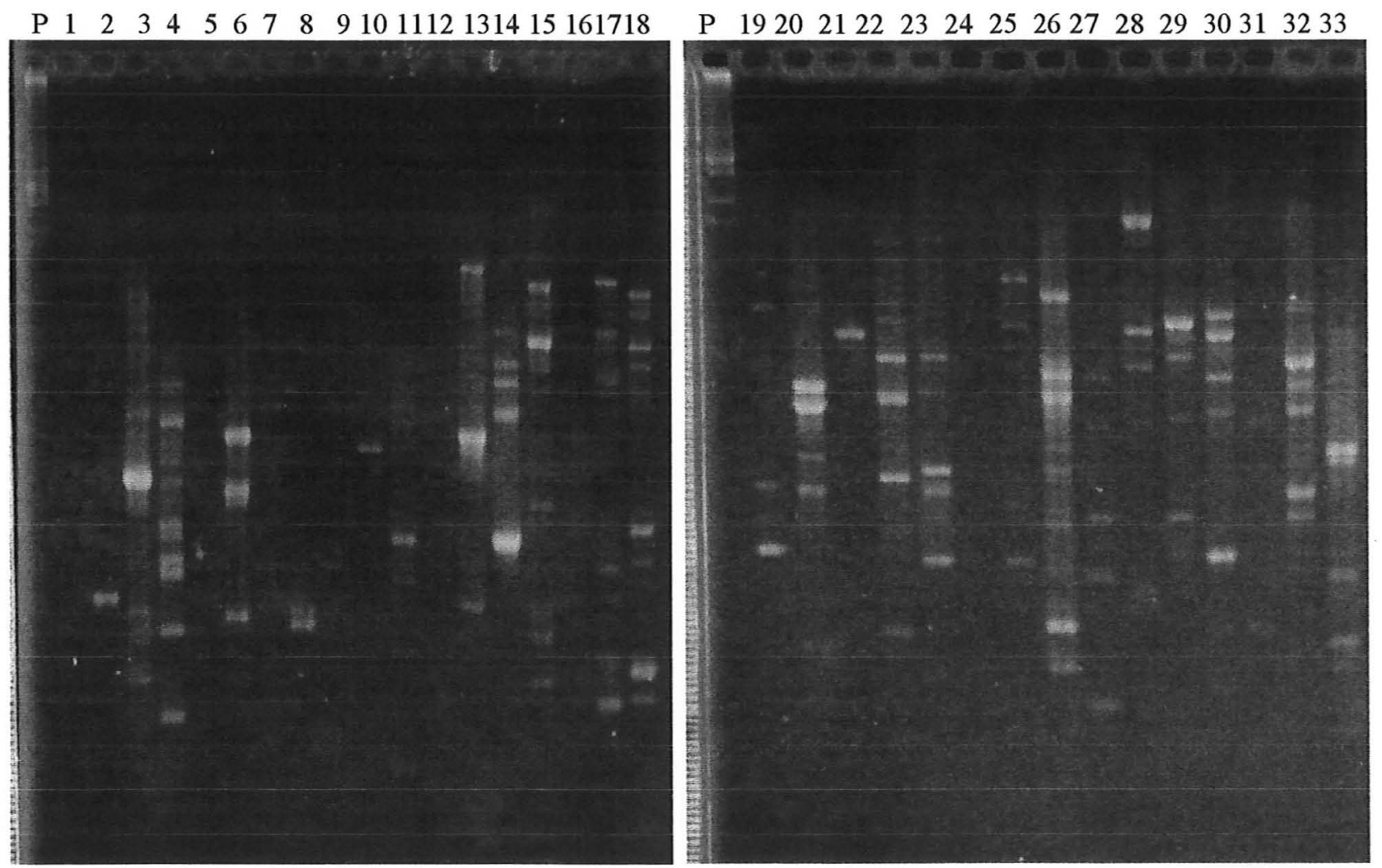

Figura 13 - Seleção de oligonucleotídeos para a reação de amplificação por RAPD, com o DNA do IAC 01/95, de dois kits da Operon (E e X); as canaletas do gel continham: P (lamda clivado); E1 (coluna 1), E2 (coluna 2), E3 (coluna 3), E4 (coluna 4), E5 (coluna 5), E6 (coluna 6), E8 (coluna 7), E9 (coluna 8), E10 (coluna 9), E11 (coluna 10), E12 (coluna 11), E13 (coluna 12), E14 (coluna13), E15 (coluna 14), E16 (coluna 15), E17 (coluna 16), E18 (coluna 17), E19 (coluna 18) P (lamda clivado); E20 (coluna 19), X1 (coluna 20), X2 (coluna 21), X3 (coluna 22), X4 (coluna 23), X5 (coluna 24), X6 (coluna 25), X7 (coluna 26), X8 (coluna 27), X9 (coluna 28), X11 (coluna 29), X12 (coluna 30), X18 (coluna 31), X13 (coluna 32), X14 (coluna 33). 


\subsection{Bandas originadas por RAPD}

Nas condições utilizadas para os isolados Phytophthora parasitica de citros, cada oligonucleotídeo amplificou em média 7,7 bandas com média de 1,62 Kb cada uma delas, o que corresponderia a $12.5 \mathrm{~Kb}$ do genoma desse fungo (Tabela 12). Levando em consideração que as estirpes estudadas são apenas uma amostragem da população do patógeno, a nossa estimativa da capacidade de detecção dessa técnica será somente para bandas que possuam uma frequência de ocorrência maior que $17 \%$ nos diferentes genótipos do patógeno nos locais amostrados e apenas $31 \%$ dos possíveis de ocorrer no Estado. Essa estimativa tendo $95 \%$ de probabilidade, como foi considerado no trabalho de Donald \& Martinez (1990).

Houve poucas bandas com polimorfismo (Figura 14), sendo que alguns oligonucleotídeos não evidenciaram nenhuma diferenciação entre os isolados (OPX - 09), os quais poderiam ser de importância ao servir de padrão multilocus, como foi realizado na determinação de um fluxo de genes para P. infestans por RFLP (Drenth et al., 1994). Esses padrões serviriam para monitorar a possível entrada no Estado de novos genótipos do patógeno, assim como tentar detectar as vias como isso poderia ocorrer.

Esse baixo número de bandas com polimorfismo era esperado, já que tanto por enzimas (Oudemans \& Coffey, 1991), como por sequências repetitivas (Panabières et al, 1989), esta espécie é uma das mais conservadas no genêro Phytophthora, sendo em alguns casos de difícil distinção entre isolados de diferentes procedências e/ou hospedeiros.

As frequências de cada fragmento amplificado variarão de 0.46 a 1.00 (Tabela 13), predominando aquelas com uma alta frequência de ocorrência entre as estirpes estudadas. 
Tabela 12 . Número de bandas amplificadas pelos oligonucleotídeos empregados na amplificação do DNA dos isolados de P. parasitica por RAPD.

\begin{tabular}{cccccccc}
\hline $\begin{array}{c}\text { Oligonu- } \\
\text { cleotídeo }\end{array}$ & $\begin{array}{c}\text { Bandas } \\
\text { amplificadas }\end{array}$ & $\mathrm{P}^{(1)}$ & $\begin{array}{c}\text { frequência } \\
\text { média }\end{array}$ & $\begin{array}{c}\text { variância } \\
\text { frequência }\end{array}$ & \multicolumn{3}{c}{ Peso molecular $(\mathrm{Kb})$} \\
E03 & 10 & 0.50 & 0.911 & 0.0180 & 1.70 & 2.60 & Máximo \\
E08 & 4 & 0.25 & 0.885 & 0.0529 & 2.45 & 4.11 & 1.19 \\
E19 & 6 & 0.50 & 0.847 & 0.0635 & 1.19 & 2.50 & 0.32 \\
X04 & 11 & 0.55 & 0.904 & 0.0123 & 1.28 & 2.67 & 0.56 \\
X07 & 7 & 0.86 & 0.769 & 0.0324 & 1.40 & 3.58 & 0.49 \\
X09 & 6 & 0.00 & 1.000 & 0.0000 & 1.50 & 3.08 & 0.59 \\
X12 & 10 & 0.40 & 0.876 & 0.0400 & 1.84 & 4.49 & 0.53 \\
& & & & & & & \\
Geral & 54 & & 0.886 & 0.0285 & & 4.49 & 0.32 \\
Média & 7.7 & 0.44 & 0.885 & 0.0049 & 1.62 & 3.29 & 0.67 \\
\hline
\end{tabular}

(1) Proporção de loci com polimorfismo das bandas amplificadas pela técnica de RAPD

A distribuição dos pesos moleculares dos fragmentos amplificados do DNA dos isolados de $P$. parasitica por RAPD pode ser visualizado na Figura 15 , tendo uma frequência de ocorrência em tôrno de 750 pares de bases, que ao serem transformados os dados pelo log dos pesos moleculares, o aspecto lembra uma distribuição normal. Apesar das diferenças forão significativas pelo teste do $\chi^{2}$, o qual pode ter ocorrido por termos poucas bandas para essa avaliação, entretanto, evidência que transformações do peso molecular das bandas poderam ser importantes para poder comparar entre diferentes olinucleotídeos e a capacidade de amplificar tamanhos de segmentos do genoma dos organismos em estudo. 
P B 1223467891011121314151617 P

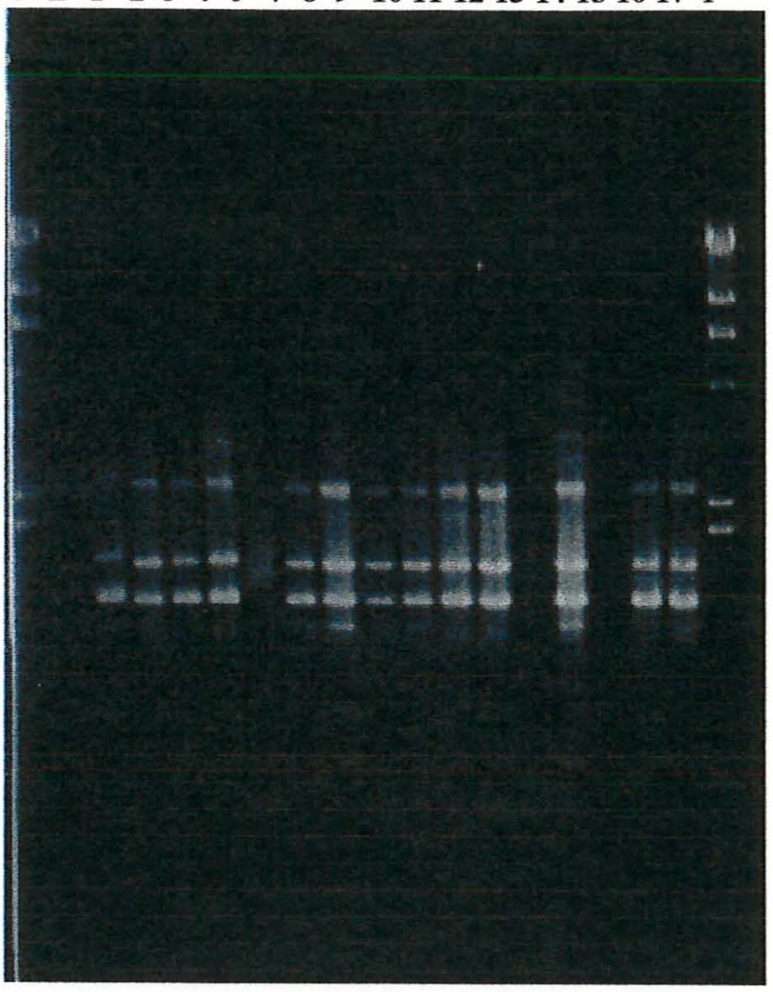

a

P B $122344677891011121314151617 \quad$ P

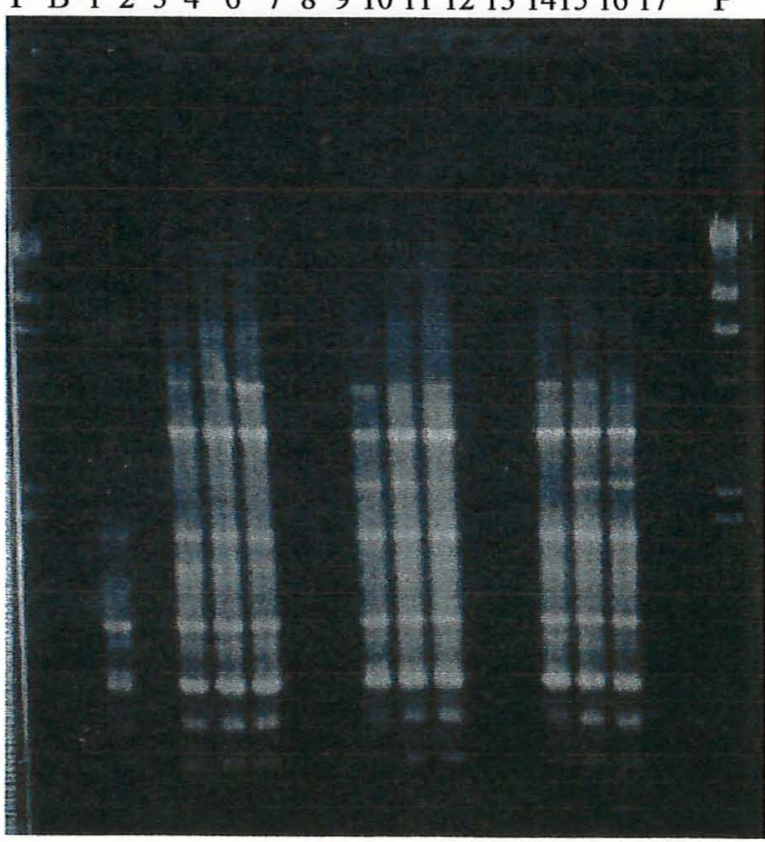

b

Figura 14 - Amplificação do DNA dos isolados de $\boldsymbol{P}$. parasitica com o oligonucleotideo a) OPE08 e b) OPX-04; os números das colunas representam os códigos das estirpes. 
Tabela 13 . Bandas amplificadas de $P$. parasitica pela técnica de RAPD, código das bandas, estimativa do peso molecular $(\mathrm{Kb})$ das bandas amplificadas $\mathrm{e}$ frequência de ocorrência.

\begin{tabular}{|c|c|c|c|c|c|}
\hline Banda & $\mathbf{P M}$ & freq. & Banda & $\mathbf{P M}$ & freq. \\
\hline E0301 & 3.08 & 0.86 & X0408 & 0.92 & 0.77 \\
\hline E0302 & 2.77 & 0.93 & X0409 & 0.81 & 1.00 \\
\hline E0303 & 2.52 & 1.00 & X0410 & 0.68 & 1.00 \\
\hline E0304 & 1.59 & 1.00 & X0411 & 0.53 & 0.77 \\
\hline E0305 & 1.24 & 1.00 & X0701 & 2.51 & 0.75 \\
\hline E0306 & 0.94 & 0.93 & X0702 & 2.02 & 0.69 \\
\hline E0307 & 0.89 & 1.00 & X0703 & 1.41 & 1.00 \\
\hline E0308 & 0.75 & 0.57 & X0704 & 0.93 & 0.94 \\
\hline E0309 & 0.68 & 1.00 & $\mathbf{X 0 7 0 5}$ & 0.64 & 0.88 \\
\hline E0310 & 0.59 & 0.86 & Х0706 & 0.55 & 0.50 \\
\hline E0801 & 2.60 & 1.00 & $\mathbf{X 0 7 0 7}$ & 0.32 & 0.63 \\
\hline E0802 & 1.67 & 1.00 & X0901 & 4.12 & 1.00 \\
\hline E0803 & 1.36 & 1.00 & $\mathbf{X 0 9 0 2}$ & 3.27 & 1.00 \\
\hline E0804 & 1.20 & 0.54 & X0903 & 2.69 & 1.00 \\
\hline E1901 & 2.67 & 1.00 & X0904 & 2.07 & 1.00 \\
\hline E1902 & 1.96 & 1.00 & X0905 & 1.57 & 1.00 \\
\hline E1903 & 1.00 & 0.93 & X0906 & 1.00 & 1.00 \\
\hline E1904 & 0.88 & 0.79 & X1201 & 3.58 & 0.92 \\
\hline E1905 & 0.63 & 0.36 & X1202 & 2.20 & 1.00 \\
\hline E1906 & 0.56 & 1.00 & $\mathbf{X 1 2 0 3}$ & 1.94 & 1.00 \\
\hline X0401 & 4.49 & 0.92 & X1204 & 1.54 & 1.00 \\
\hline X0402 & 3.43 & 1.00 & $\mathbf{X 1 2 0 5}$ & 1.31 & 1.00 \\
\hline X0403 & 2.54 & 0.71 & X1206 & 1.02 & 1.00 \\
\hline X0404 & 2.06 & 0.85 & $\mathbf{X 1 2 0 7}$ & 0.71 & 0.67 \\
\hline X0405 & 1.88 & 1.00 & X1208 & 0.65 & 0.42 \\
\hline X0406 & 1.77 & 0.92 & X1209 & 0.59 & 0.75 \\
\hline X0407 & 1.16 & 1.00 & $\mathbf{X 1 2 1 0}$ & 0.49 & 1.00 \\
\hline
\end{tabular}




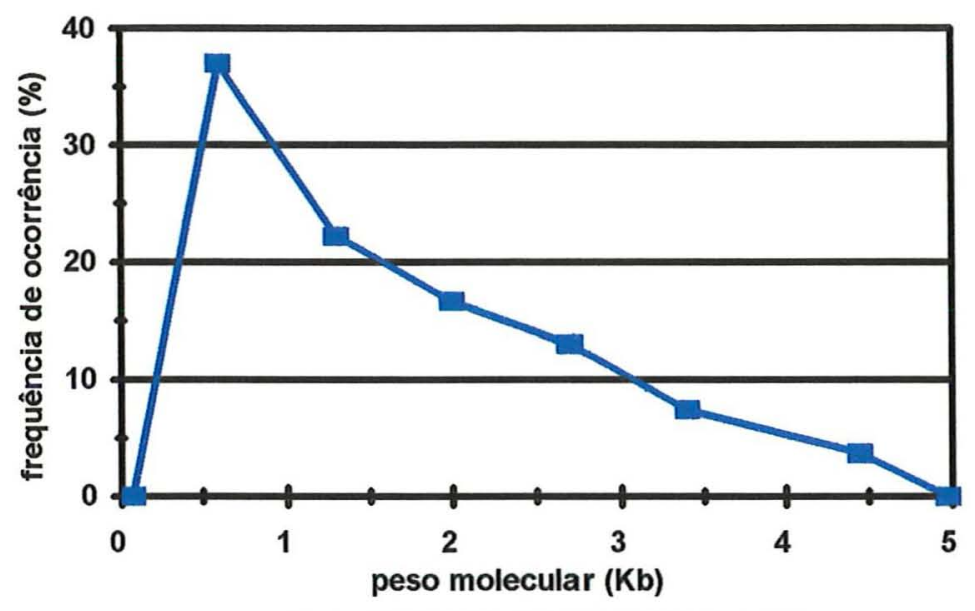

E Phytophthora parasitica

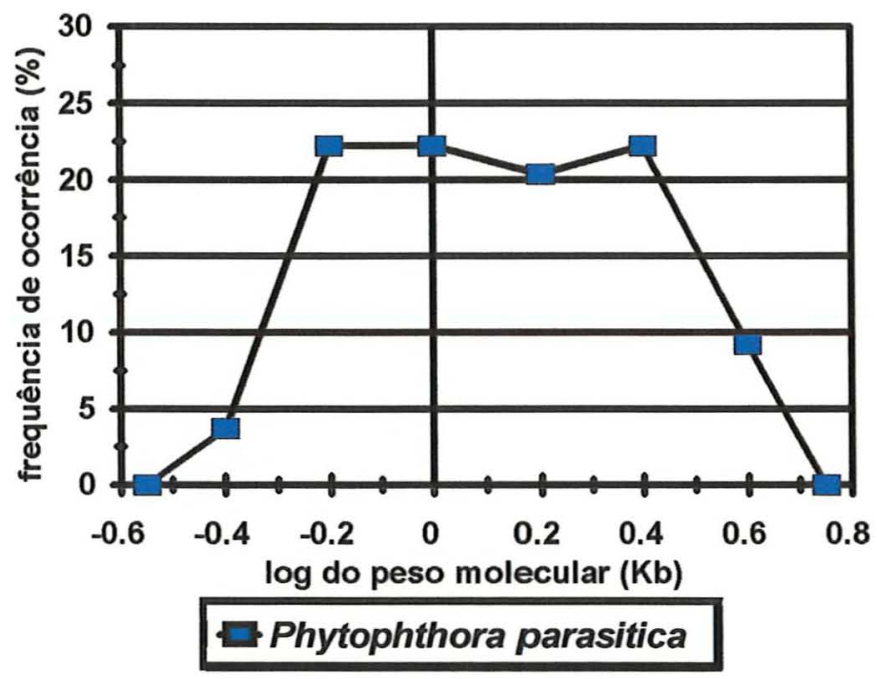

b

Figura 15 - Distribuição dos fragmentos de DNA amplificados de $P$. parasitica (a) escala linear (b) escala logarítmica. 


\subsection{Polimorfismo obtido por RAPD}

A análise conjunta das bandas obtidas pelos diferentes oligonucleotídeos pode ser observada pela Figura 16.

A detecção de diferenças mesmo de isolados monozoospóricos poderia ser devido à capacidade de ocorrer heterocários naturais nesse grupo, assim como à possível capacidade de fusão de zoósporos ou hifas de genótipos diferentes. $O$ qual não pode ser detectado pela mensuração das características morfológicas dos isolados estudados.

A hipótese de fusão de genótipos é uma das indagações da possível ocorrência de ciclo parasexual ou mesmo parameiose, mesmo sendo organismos diplóides, entretanto talvez o termo mais correto deva ser hibridação somática. Essa possibilidade vem sendo fortalecida pela obtenção artificial de híbridos interespecíficos, pelo uso de PEG e sais de lítio; e subsequente detecção de indivíduos híbridos (Érsek et al., 1995). Essa hipótese vem indagar sobre a ocorrência numa frequência muito baixa de fluxo de genes entre espécies (introgressão), ou mesmo poderia ser relativamente comum intraespecificamente. 


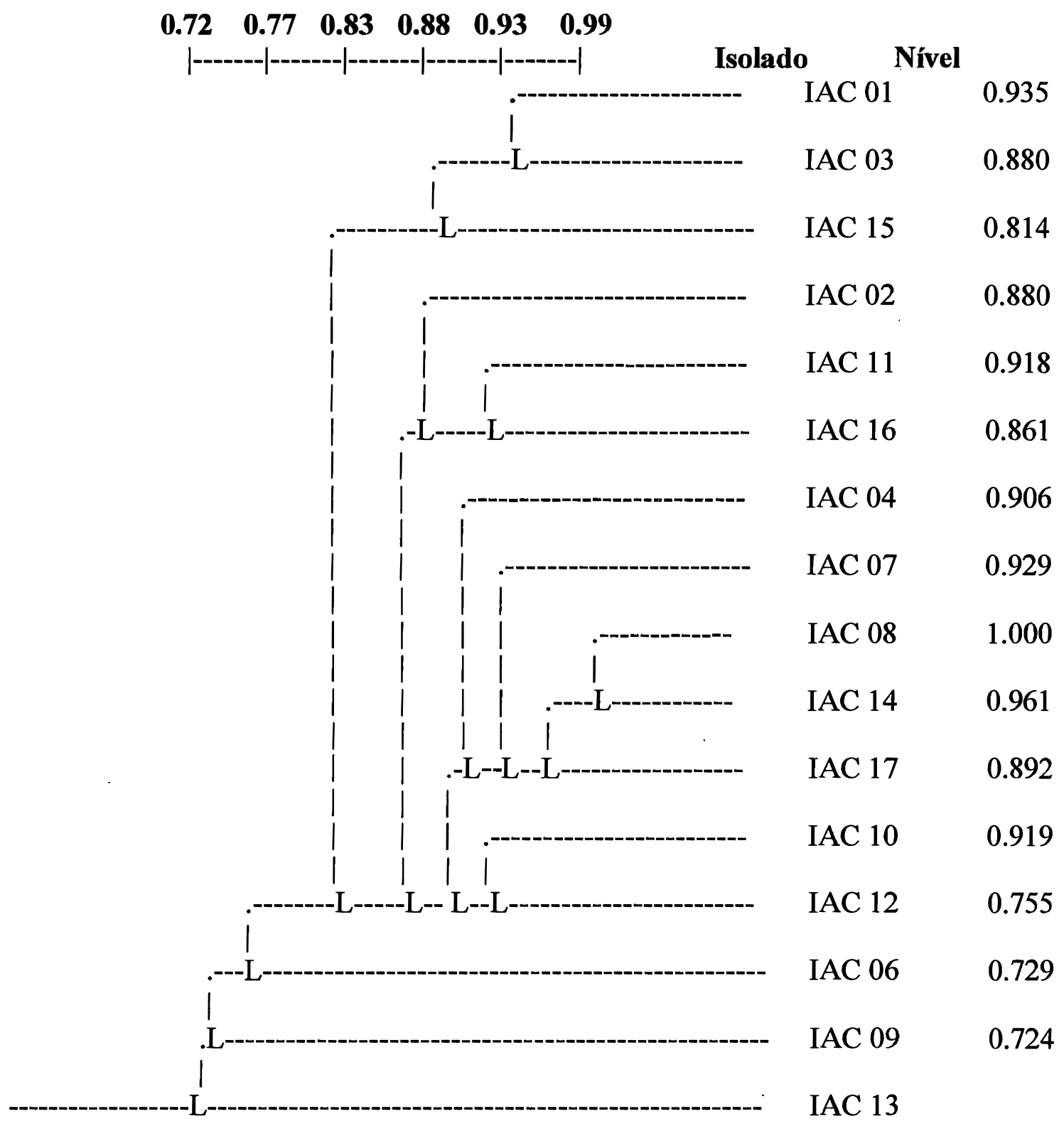

Figura 16 - Dendrograma a partir dos dados de RAPD dos isolados. 


\subsection{Dados moleculares $x$ fenótipos}

A não ocorrência de relação entre locais e isolados monozoospóricos tolerantes ao metalaxyl pode ser explicada como devida à ausência de seleção nesses locais. Entretanto, pode-se considerar que haja uma certa percentagem de tolerância natural. Isso cria a necessidade de maiores cuidados quanto ao uso desse grupo de fungicidas para o controle do patógeno, haja visto que os isolados foram obtidos até 1994, e o produto foi oficialmente liberado para a cultura dos citros somente em 1995.

Essa tolerância pode ser explicada de duas maneiras: a primeira seria uma característica intrínseca das populações de Phytophthora associadas aos citros no Estado de São Paulo, e a outra de que muitas das águas empregadas para irrigação de viveiros e/ou pomares estejam sendo contaminadas com baixas concentrações do produto (subdosagens), empregada em outras culturas, principalmente hortícolas, que estariam contaminando os rios ou mesmo os lençóis freáticos; o qual estaria há muito tempo levando a uma seleção mas, com baixa pressão. Essa tolerância natural poderá facilitar grandemente o surgimento de biótipos altamente tolerantes ao metalaxyl e consequentemente quebrar rapidamente a eficiência desse grupo de fungicidas antioomicetos.

A falta de correlação com os dados moleculares obtidos pela técnica de RAPD, pode ser devida principalmente ao fato da tolerância ter surgido por mutação em apenas poucos genes, os quais devem ter pouca importância na capacidade adaptativa desses patógenos, diferentemente do que ocorreu em $P$. infestans, o qual teve que ocorrer um fluxo de genes do Novo Continente para a Europa, os quais conferiram estabilidade a esse fenótipo pela capacidade de recombinação dos outros genes, tornando mais adaptados os genótipos com tolerância.

Há necessidade de evitar o que está ocorrendo nos Estados Unidos, onde mais de $60 \%$ dos viveiros de plantas cítricas já estão com tolerância. Essa tarefa toma-se mais árdua devido à tolerância natural dessa população. É de fundamental importância a conscientização dos produtores de mudas de não usar o grupo das fenilamidas nos viveiros, somente outros sistêmicos ou protetores, assim como as outras precauções 
recomendadas para a produção de mudas isentas de Phytophthora e nematóides (Feichtenberger, 1996).

Esses resultados estão em concordância com os encontrados para Alternaria alternata (Adachi, et. al., 1996), no qual não houve correlação entre a diversidade genética e/ou grupos genéticos obtidos por RFLP com a característica de resistência a polyoxin. Isso mostra que não deve ocorrer necessidade de blocos gênicos para esse fenótipo, somente algumas mutações por simples pressão de seleção em grupos geneticamente distintos. Isto também vem sendo detectado em raças de patógenos, como em Phytophthora sojae (Drenth, et. al., 1996), no qual pode ocorrer maiores similaridades entre indivíduos de raças diferentes, do que dentro das raças. Isso era considerado pelos fitopatologistas como uma forma de determinar a variabilidade de um patógeno. Evidentemente esse conceito tem que ser revisto, pois constitui-se em uma visão reducionista da variabilidade da capacidade de quebra de genes de resistência do hospedeiro, quando outros genes ou variações destes podem ter grande importância na disseminação e principalmente na sobrevivência e predominância de genótipos.

Essa visão foi grandemente afetada pela repentina quebra da resistência de genes de resistência em batata, novamente em $P$. infestans, o qual deve-se sem sombras de dúvidas à migração de novos genótipos (novos genes de adaptação), que permitiram a mudança do patógeno de uma propagação clonal, para uma sexual. Essa nova capacidade de cruzamento entre o antigo A2 e o novos genótipos A1, permitiram recombinação dos genes e ao mesmo tempo uma maior adaptação devido ao próprio esporo sexual ser extremamente resistente às condições adversas, levando à quebra do manejo da doença.

Não somente a nova fonte de inoculo foi confirmada, mas houve quebra da resistência de variedades que a muitos anos vinham mantendo-se estáveis, assim como uma resistência ao metalaxyl, um dos principais fungicidas para o controle dessa doença, por tomar esses genótipos estáveis, os quais anteriormente existiam mas não se conseguiam manter ou predominar nas populações da Europa. 


\section{CONCLUSÕES}

1. Isolados de Phytophthora parasitica diferem quanto às dimensões dos seus esporângios e à capacidade de produção de clamidósporos em meio de cultura.

2. O aspecto das culturas não é uma característica importante para a identificação de $P$. parasitica.

3. Os dados mostram que tolerância natural até 10 ppm já ocorre em populações nativas no Estado de São Paulo.

4. A técnica de RAPD foi capaz de distinguir entre diferentes estirpes de P. parasitica.

5. Presença de heterocarions nas culturas originais de $P$. parasitica.

6. Há uma alta similaridade genética nessa espécie, entre populações diferentes, entretanto pode haver maior divergência entre isolados de um mesmo local do que de origens diferentes.

7. Não há correlação entre os agrupamentos RAPD e tolerância ao metalaxyl. 


\section{ANEXO 1}

Chave de identificação de espécies de Phytophthora associadas a citros, sem a necessidade das estruturas sexuais:

1. Esporângios papilados (Grupo I ou II)...................................... 2

Esporângios semi-papilados (Grupo III ou IV)............................

Esporângios não papilados (Grupo V ou VI)...............................

2. Esporângios persistentes...........................................................

Esporângios caducos.............................................................

3. Temperatura máxima entre 35 e $40^{\circ} \mathrm{C}$;

Comprimento dos esporângios $<60 \mu \mathrm{m}$;

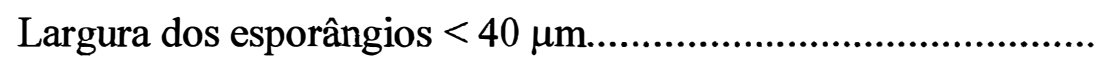

Temperatura máxima entre 30 e $35^{\circ} \mathrm{C}$;

Comprimento dos esporângios $<90 \mu \mathrm{m}$;

Largura dos esporângios $<60 \mu \mathrm{m}$

P. citrophthora

4. Pedicelo curto $(<5 \mu \mathrm{m})$.

Pedicelo médio (entre 5 e $20 \mu \mathrm{m}$ )

NAC

Pedicelo comprido $(>20 \mu \mathrm{m})$

P. capsici

5 Não forma clamidósporos.....................................................

Clamidósporos de paredes finas.................................................

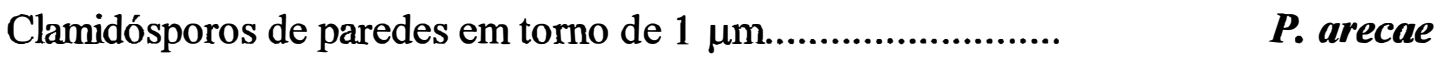

Clamidósporos de paredes grossas de $2 \mu \mathrm{m}$ 
6. Produção de esporângios em simpodio com até

20 esporângios.

P. palmivora

Não produz esporângios em simpódio

P. cactorum

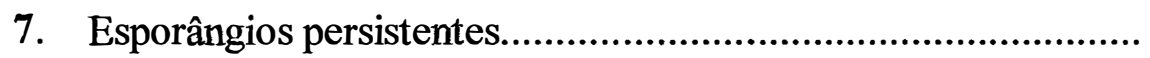

Esporângios caducos

P. hibernalis

8. Crescimento a $28^{\circ} \mathrm{C}$

P. citricola

Não há crescimento a $28^{\circ} \mathrm{C}$

P. syringae

9. Esporângios persistentes com proliferação interna e/ou externa... 10 Esporângios caducos

NAC

10. Nunca produz clamidósporos

P. megasperma

Produz clamidósporos ou alguns isolados não produzem.

11. Clamidósporos com diâmetro $>30 \mu \mathrm{m}$.

P. cinnamomi

Clamidósporos com diâmetro $<20 \mu \mathrm{m}$

P. drechsleri

NAC Possível espécie ainda não associada aos citros

Observação: Sempre deve-se confirmar com a literatura especializada a espécie que aparentemente foi identificada, para confirmação das suas caracteristicas; além de que isto é apenas uma simplificaçaõ para uma identificação mais rápida, sem necessidade de estruturas sexuais, que nem sempre são possíveis de obter em condições de laboratório. 


\section{REFERÊNCIAS BIBLIOGRÁFICAS}

ADACHI, Y.; WATANABE, H.; TSUGE, T. Relationships between genetic polymorphisms and fungicide resistance within Alternaria alternata. Phytopathology, v.86, p.1248-1254, 1996.

ALFENAS, A. C.; PETERS, I.; BRUNE, W.; PASSADOR, G. C. Eletroforese de proteinas e isoenzimas de fungos e essências florestais. Viçosa, SIF, 242p. 1991.

AMORIM, E.P.D. Controle biológico de Phytophthora parasitica var. nicotianae Dastur e Phytophthora citrophthora (Smith \& Smith) Leonian em plântulas de citros. Botucatu, 1997. 111p. Tese - Faculdade de Ciências Agrárias, Universidade Estadual Paulista.

ANAGNOSTAKIS, S. L. Diversity within populations of fungal pathogens on perennial parts of perennial plants. In: CARROL, G. C. \& WICKLOW, D. T. (Ed.) The fungal community: its organization and role in the ecosystem. New York: Marcel Dekker, Inc. 1992. (Mycological Series, v.9)

ARAÚJO, W.L. de Isolamento, identificação e caracterização genética de bactérias endofiticas de porta-enxertos de citros. Piracicaba, 1996. 85p. Dissertação - Escola Superior de Agricultura "Luiz de Queiroz", Universidade de São Paulo.

AVERNA-SACCÁ, R. Moléstias das laranjeiras. Boletim Agrícola , v.18, p.334-346, 1917.

BITANCOURT, A. A. A podridão do pé das laranjeiras (Gomose). São Paulo: Instituto Biológico, 1936, 15p. (Folheto 81) 
CACCIOLA, S.O.; MAGNANO di san LIO, G.; BELISARIO, A. Phytophthora italica sp. Nov. on myrtle. Phytopathologia Mediterranea, v.35, p.415-418, 1996.

CARNE, W. M. A brown rot of citrus in Australia (Phytophthora hibernalis n. sp.). Journal Royal Society Westhern Australia, v.12, p13-41, 1925.

CARTER, D. A.; ARCHER, S. A.; BUCK, K. W.; SHAW, D. S.; SHATTOCK, R. C. Restriction fragment length polymorphisms of mitochondrial DNA of Phytophthora infestans. Mycological Research, v. 94, p.1123-1128, 1990.

COOKE, D.E.L.; KENNEDY, D.M.; GUY, D.C.; RUSELL, J.; UNKLES, S.E.; DUNCAN, J.M. Relatedness of group I species of Phytophthora as assessed by randomly amplified polymorphic DNA (RAPDs) and sequences of ribosomal DNA. Mycology Research, v.100, p.297-303, 1996.

CRISTOFANI, M. Mapas de ligação de Citrus sunki Hort. Ex. Tan. e Poncirus trifoliata (L.) Raf. cv. Rubidoux e localização do gene de resistência a tristeza. . Piracicaba, 1997. 85p. Dissertação - Escola Superior de Agricultura "Luiz de Queiroz", Universidade de São Paulo.

CROWHURST, R. N.; HAWTHORNE, B. T.; RIKKERINK, E. H. A.; TEMPLETON, M. D. Differentiation of Fusarium solani f. sp. cucurbitae races 1 and 2 by random amplification of polymorphic DNA. Current Genetics, v.20, p.391-396, 1991.

DELP, C. P. Coping with resistance to plant disease control agents. Plant disease, v. 64, 652-657, 1980.

DHINGRA, O. D.; SINCLAIR, J.B. Basic plant pathology methods. CRC Press, Inc. Boca Raton Florida. 1985. 355 p. 
DOIDGE, E.M. Brown rot in citrus fruits (Phytiacystis citrophthora R. and E. Smith). Journal Development Agriculture South Africa, v.10, p. 499 - 503, 1925

DRENTH, A., WHISSON, S. C., MACLEAN, D.J., IRWIN, J.A.G., OBST, N.R., AND RYLEY, M. J. The evolution of races of Phytophthora sojae in Australia. Phytopathology, v.86, p.163-169, 1996.

DRENTH, A., TAS, I. C. Q.; GOVERS, F. DNA fingerprinting uncovers a new sexually reproducing population of Phytophthora infestans in the Netherlands. European Journal of Plant Pathology, v.100, p.97-107, 1994.

ECKERT, J. W. Historical development of fungicide in plant pathogens. In: DELP, C. J. Fungicide resistance in North America. APS. St. Paul, Minnesota. 1988. p.1-3.

EGGER, K. N. Analysis of fungal population struture using molecular techniques. In: CARROL, G. C. \& WICKLOW, D. T. (Ed.) The fungal community: its organization and role in the ecosystem. New York: Marcel Dekker, Inc. 1992. (Mycological Series, v.9)

ÉRSEK, T.; ENGLISH, J. T.; SCHOELZ, J. E. Creation of species hybrids of Phytophthora with modified host ranges by zoospores fusion. Phytopathology, v.85, p.1343-1347, 1995.

ÉRSEK, T.; HÖLKER, U.; HÖFER, M. Non-lethal immobilization of zoospores of Phytophthora infestans by Li+. Mycological Research, v.95, p.970-972, 1991.

ERWIN, D.C.; RIBEIRO, O.K. Phytophthora Diseases worldwide. St. Paul: APS Press, 1996. 562p. 
EVANS, H. C.; PRIOR, C. Cocoa pod diseases: Causal agents and control. Outlook Agricola, v.16, p.35-41. 1987

FAWCETT, H. S. Citrus diseases of Florida and Cuba compared with those of California. California Agricultural Experimental Station Bulletin, v.262, p.1-62, 1915.

FAWCETT, H. S. Phythiacystis and Phytophthora. Phytopathology, v.10, p.397-399, 1920.

FAWCETT, H. S. New locations for Phytophthora citrophthora and P. hibernalis on Citrus . Phytopathology, v.23, p. 667-669, 1933.

; FAWCETT, H. S. Citrus disease and their control. Segunda edição. McGraw-Hill Book Company,Inc. NewYork e London. 1936. 656 p.

FAWCETT, H.S.; BITANCOURT, A.A. Occurrence, pathogenicity, and temperature relations of Phytophthora species on citrus in Brazil and other south american countries. Arquivos do Instituto Biológico, v.11, p.107-118, 1940.

FEICHTENBERGER, E. Doenças induzidas por fungos do gênero Phytophthora em citros e seu controle. Laranja, Cordeirópolis, v.10, p.359-378, 1989.

FEICHTENBERGER, E. Manejo ecológico de gomose de Phytophthora dos citros São Paulo:Rhodia Agro ltda, 42p. 1996.

FEICHTENBERGER, E.; ZENTMYER, G.A.; MENGE, J.A. Identity of Pythophthora isolated from milkweed vine. Phytopathology, v.74, p.50-55, 1984. 
FERREIRA, M. E.; GRATTAPAGLIA, D. Introdução ao uso de marcadores RAPD e RFLP em análise genética. Brasilia: EMBRAPA-CENARGEN, 220 p. 1995.

FÖSTER, H.; KINSCHERF, T. G.; LEONG, S. A.; MAXWELL, D. P. Restriction fragment length polymorphisms of the mitochondrial DNA of Phytophthora megasperma isolated from soybean, alfafa, and fruit trees. Canadian Journal of Botany, v.67, p.529-537, 1989.

FRY, W. E.; GOODWIN, S. B.; DYER, A.T.; MATUSZAK, J. M.; DRENTH, A.; TOOLEY, P.W.; SUJKOWSKI, L. S.; KOH, Y. J.; COHEN, B. A.; SPIELMAN, L. J.; DEALH, K. L.; INGLIS, D. A.; SANDLAN, K. P. Historical and recent migrations of Phytophthora infestans: chronology, pathways, and implications. Plant Disease, v.77, p.653-661, 1993.

FREZZI, M. J. Phytophthora boehmeriae, causante de la podredumbre morena de los frutos citricos, en la Republica Argentina. Revista Argentina de Agronomia, v.8, p.200-205. 1941.

GLIENKE, C. Variabilidade genética no fungo endofitico Guignardia citricarpa Kiely detectada por RAPD. Curitiba, 1995. 115p. Dissertação - Universidade Federal do Paraná.

GOODWIN, S. B.; COHEN, B. A.; DEAHL, K. L.; FRY, W. E. Migration from northern Mexico as the probable cause of recent genetic changes in populations of Phytophthora infestans in the United States and Canada. Phytopathology, v.84, p.553-558, 1994.

GRATTAPAGLIA, D.; BERTOLUCCI, F. L.; SEDEROFF, R. R. Genetic mapping of quantitative trait loci controlling vegetative propagation in Eucalyptus grandis and 
E. urophylla using a pseudo-testcross strategy and RAPD markers. Genetics v.90, p.933-947, 1995.

HAJEK, A. E.; HODGE, K. T.; LIEBHERR, J. K.; DAY, W. H.; VANDENBERG, J. D. Use of RAPD analysis to trace the origin of the weevil pathogen Zoophthora phytonomi in North America. Mycological Research, v.100, p.349-355, 1996.

HALL, G.; DOBSON, , S.; NICHOLLS, C. First record of Phytophthora inflata in the United Kingdom. Plant Pathology, v.41, p. 95-97, 1992.

HO, H. H. Hyphal branching system in Phytophthora and other phycomycetes. Mycopathologia, v. 64, p.83-86, 1978

HO, H. H. Synoptic keys to the species of Phytophthora. Mycologia, v.73, p.705-714, 1981.

HO, H. H.; JONG, S. C. Halophytophthora gen. Nov., a new member of the family Pythiaceae. Mycotaxon, v.36, p.377-382, 1990.

IZIOKA, E. E. K.; SOUZA, N. L.; MACHADO, M.; LOPES, C. R. Caracterização morfológica, patogênica e molecular de Colletotrichum gloeosporioides, agente causal da podridão floral dos citros. Fitopatologia Brasileira (suplemento), v.20, p.379, 1995.

KENNEDY, D. M.; DUNCAN, J. M. A papillate Phytophthora species with specificity to Rubus. Mycological Research, v.99, p57-68, 1995.

KIMATI, H. Controle químico. Capítulo 38. In: BERGAMIN FILHO, A.; KIMATI, H.; AMORIM, L. (editores). Manual de Fitopatologia. vol. 1. Princípios e conceitos. 3 Edição. Editora Agronômica Ceres Ltda., São Paulo. 1995. p. 761-785 . 
LEONIAN, L.H. Physiological studies on the genus Phytophthora. American Journal of Botany, v.12, p.444-498, 1925.

LEONIAN, L. H. Identification of Phytophthora species. West Virginia Agriculture Experiment Station Bulletin. v.262, p. 1-36, 1934.

LUZ, E. D. M. N.; MATSUOKA, K. Taxonomia e sistemática do gênero Phytophthora. Revisão Anual de Patologia de Plantas, v.4, p.297-328, 1996.

McDONALD, B. A.; MARTINEZ, J. P. DNA restriction fragment length polymorphisms among Mycosphaerella graminicola (Anamorph Septoria tritici) isolates collected from a single wheat field. Phytopathology, v.80, p.1368-1373, 1990.

MACHADO, M. A.; COLETTA FILHO, H.D.; TARGON, M.L.P. N.; POMPEU JR., J. Genetic relationship of mediterranean mandarins (Citrus deliciosa Tenore) using RAPD markers. Euphytica, v.92, p.321-326, 1996.

MAIA, R. M. da Um novo oomycete parasita de árvores do gênero Citrus? Revista agronômica, Lisboa, v.41, p11, 1925.

MAY, L.L. Controle biológico, físico e químico de Phytophthora parasitica Dastur em mudas de citros. Piracicaba, 1994. 89p. Dissertação - Escola Superior de Agricultura "Luiz de Queiroz", Universidade de São Paulo.

McBLAIN; B. A.; ZIMMERLY, M. M.; SCHMIITTHENNER, A. F.; HACKER, J. K. Tolerance to Phytophthora rot in soybean: I. Studies of the cross 'Ripley $x$ Harper'. Crop Science, v. 31, p. 1405-1411, 1991. 
McDONALD, B.A.; MARTINEZ, J.P. DNA restriction fragment legth polymorphisms among Mycosphaerella graminicola (anamorph Septoria tritici) isolates collected from a single wheat field. Phytopathology, v.80, p.1368-1373, 1990.

MÜLLER, A. S. Observations and notes on citrus diseases in Minas Geraes, Brazil. Phytopathology, v.23, p. 734-737, 1933.

NARASIMHAN, M. J. Wild plants affected by koleroga. Mysore Agricole Calendar, p. 36-37. 1927.

NEWHOOK, F. J.; WATERHOUSE, G.M.; STAMPS, D.J. Tabular key to the species of Phytophthora de Bary. Commonwelt Mycological Institute, 20 p., 1978. (Mycological Papers 143)

OUDEMANS, P. \& COFFEY, M. A revised systematics of twelve papillate Phytophthora species based on isozyme analysis. Mycological Research, v.95, p. 1025-1046, 1991.

PACCOLA-MEIRELLES, L. D.; VALARINI, M. J.; AZEVEDO, J. L.; ALFENAS, A. C. Manual de Técnicas Eletroforéticas em Microrganismos. Escola Superior de Agricultura "Luiz de Queiroz". Ed. FEALQ, Piracicaba, Brasil, 54 p., 1988.

PANABIĖRES, F.; MARAIS, A.; TRENTIN, F.; BONNET, P.; RICCI, P. Repetitive DNA polymorphism analysis as a tool for identifying Phytophthora species. Phytopathology, v.79, p.1105-1109, 1989.

REINKING, O. A. Citrus diseases in the Philippines, Southern China, and Siam. Philippine Agriculture, v.9, p.121-179, 1921. 
ROSSETTI, V. Estudos sobre a gomose de Phytophthora de citrus. - I. Susceptibilidade de diversas espécies cítricas a algumas espécies de Phytophthora. Arquivos do Instituto Biológico, v.18, p.97-124, 1947.

ROSSETTI, V.; MELLO, O.F.; PENTEADO, L.B.K.; OLIVEIRA, D.d. Estudo das espécies e cepas de Phytophthora isoladas de pomares cítricos no estado de São Paulo, e sua patogênia. In: CONGRESSO BRASILEIRO DE FRUTICULTURA, Anais. SBF, 1972. p.505-526.

SAMBROOK, J.; FRITSCH, E. F; MANIATIS, T.; Molecular cloning - A laboratory manual. Second edition, Cold Spring Harbor Laboratory Press, New York, 1989.

SAWADA, K. Drescriptive catalogue of the Formosan fungi. Formosa Bulletin, v.27, p.1-62, 1927

SMITH, R. E. \& SMITH, E. H. A new fungus of economic importance. Botanical Gazete, v.42, p.215-221, 1906.

STAMPS, D.J.; WATERHOUSE, G.M.; NEWHOOK, F.J.; HALL, G.S. Revised tabular key to the species of Phytophthora. CAB Internacional Mycological Institute, 1990. 28p. (CAB. Mycological papers,162)

STEVENS, H. E. Florida Citrus diseases. Florida Agriculture Experiment Station Bulletin, v.150, p. 1-96, 1918.

TIMMER, L. W.; MENGE, J. A. Phytophthora-induced diseased. In: WHITESIDE, J. O.; GARNSEY, S.M.; TIMMER, L. W. Compendium of Citrus Diseases. APS Press. p. 22-24. 1996.

TUCKER, C. M. Taxonomy of the genus Phytophthora de Bary. Missouri Agriculture Experiment Station Research Bulletin. 153, 208 p., 1931 
VASCONCELOS, M. J. V. de; MACHADO, M. A.; ALMEIDA, A, M. R.; HENNING, A. A.; BARROS, E. G. de; MOREIRA, M. A. Differentiation of Colletotrichum truncatum isolates by random amplified polymorphic DNA. Fitopatologia brasileira, v.19, p. 520-523, 1994.

WATERHOUSE, G. M. Key to the species of Phytophthora de Bary. Mycological Papers, 92. Commonwell Mycology Institute, England. 22p. 1963

WATERHOUSE, G.M.; NEWHOOK, F.J.; STAMPS, D.J. Present criteria for classification of Phytophthora. In: ERWIN, D.C.; BARTNICKI-GARCIA, S.; TSAO, P.H. (Ed.) Phytophthora. Its biology, taxonomy, ecology, and pathology. St. Paul, Minnesota:The american phytopathological society, 1983. cap.10, p.139147.

WELSH, J.; McCLELLAND, M. Fingerprinting genomes using PCR with arbitrary primers. Nuclei Acids Research, v.18, p. 7213-7218, 1990.

WIANT, J. S.; TUCKER, C. M. A rot of winter queen watermelons caused by Phytophthora capsici. Journal Agricultural Research, v.60, p.73-88, 1940

WILLIANS, J. G.K.; KUBELIK,A.R.; LIVAK, K.J.; RAFALSKI, J.A.; TINGEY, S.V. DNA polymorphisms amplified by arbitrary primers are useful as genetic markers. Nuclei Acids Research, v.18, p.6531-6535, 1990.

ZAMBOLIM, L.; VALE, F.X.R. do. Perdas ocasionadas pelas doenças de plantas. In: EPAMIG Informe agropecuário. Doenças de plantas I. Belo Horizonte. EPAMIG, ano 11, n.122. p. 1-9, 1985.

ZENTMEYER, G. A. The world of Phytophthora In: Erwin, D.C.; Bartnick-Garcia, S.; Tsao, P. H. Phytophthora. It's biology, taxonomy, ecology and pathology. p.1-8. 1983. 